\title{
GRED STUDIES AND DRILLING OF AMERICULTURE STATE 2, AMERICULTURE TILAPIA FARM LIGHTNING DOCK KGRA, ANIMAS VALLEY, NM
}

\author{
James C. Witcher \\ Witcher and Associates \\ P.O. Box 3142 \\ Las Cruces, NM 88003
}

FINAL TECHNICAL REPORT

Submitted to:

AMERICULTURE

COTTON CITY, NEW MEXICO

August 2006 


\section{DISCLAIMER}

This report was prepared to document work sponsored by the United States Government. Neither the United States nor its agent, the United States Department of Energy (DOE), nor any Federal employees, makes any warranty, express or implied, or assumes any legal liability or responsibility for the accuracy, completeness, or usefulness of any information, apparatus, product, or process disclosed, or represents that its use would not infringe privately owned rights. Reference herein to any specific commercial product, process, or service by trade name, trademark, manufacturer, or otherwise, does not necessarily constitute or imply its endorsement, recommendation, or favoring by the United States Government or any agency thereof. The views and opinions of authors expressed herein do not necessarily state or reflect those of the United States Government or any agency thereof. 


\section{ACKNOWLEDGEMENTS}

This report on the GRED II drilling activities and results and on the geochemistry and isotopic systematics of the Lightning Dock geothermal water was performed for AmeriCulture, Inc. with the support of US Department of Energy. Damon Seawright has been a champion of this work and his assistance throughout has been crucial. Dale Burgett of Burgett Geothermal Greenhouses has been very gracious in allowing access to his property for well sampling and temperature logging of wells. Drilling activities were greatly augmented by Don Brown, Dick Hahman, and Marie Guerrero. Ron Jacobson and Joe Henfling of Sandia National Laboratory are thanked for obtaining equilibrium temperature logs with the Sandia wireline tools and the core tube logger (CTL) tool. Sam Bothern is thanked for his valuable assistance during geochemical sampling. The drilling contractors and crews, Boart Longyear and Lang, performed some magnificent problem solving during the deepening of the AM-2 well. 


\section{TABLE OF CONTENTS}

INTRODUCTION

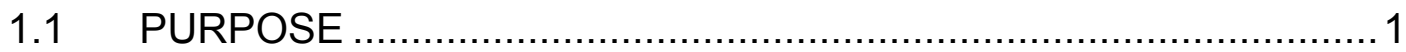

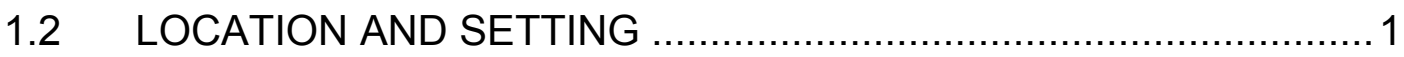

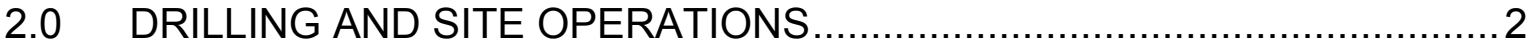

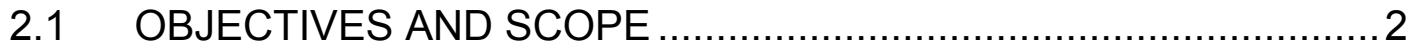

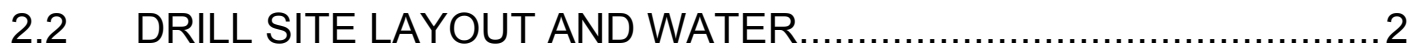

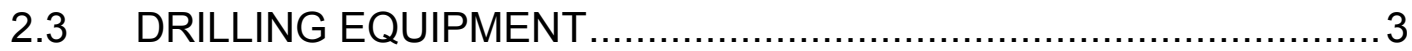

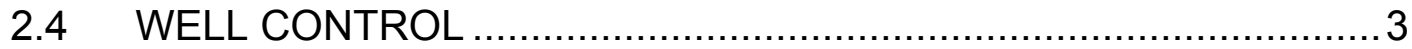

2.5 HYDROGEN SULFIDE MONITORING ….............................. 3

2.6 WELL SITE GEOLOGY AND OPERATIONS MONITORING ...........4

2.7 DRILLING SUMMARY AND ANALYSIS .................................... 4

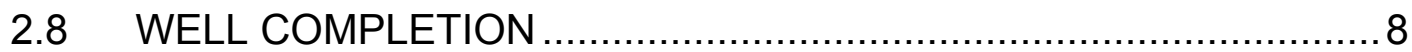

2.9 GEOPHYSICAL AND TEMPERATURE LOGGING ....................

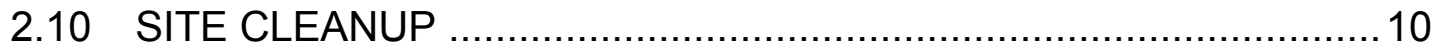

3.0 GEOLOGY AND THERMAL REGIME ….......................................... 11

3.1 SUMMARY GEOLOGIC LOG OF WELL .................................. 11

3.2 DISCUSSION AND SYNTHESIS OF GEOLOGY .......................15

3.3 TEMPERATURE LOGS AND INTERPRETATION .........................22

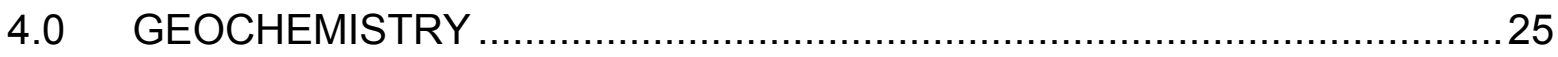

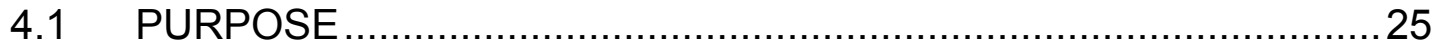

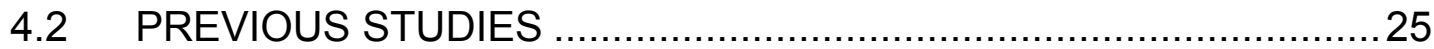

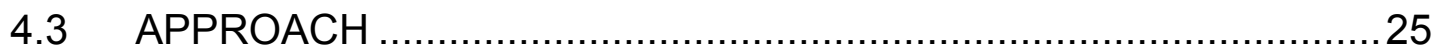

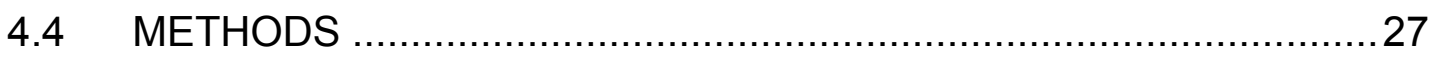

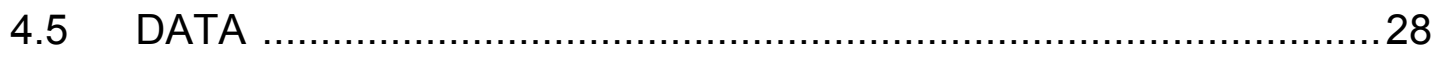

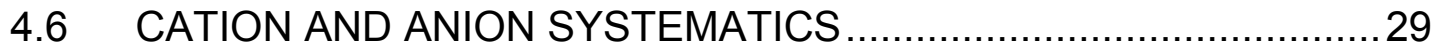

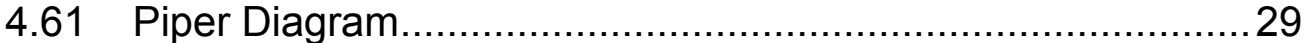

4.62 Bromide and Chloride/Bromide Ratio ................................. 30

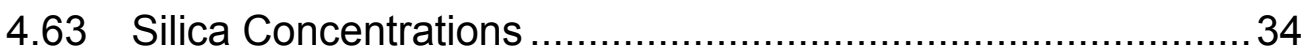

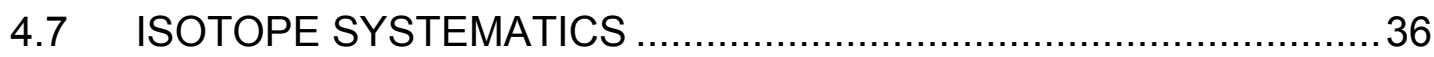

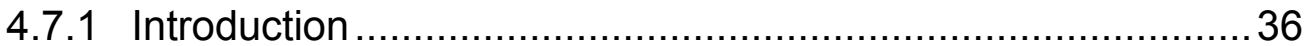

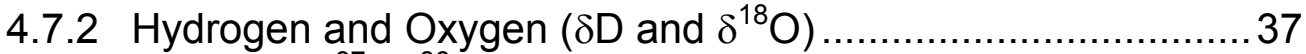

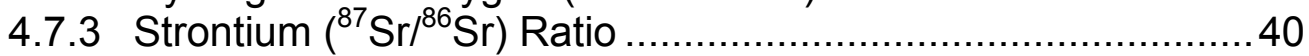

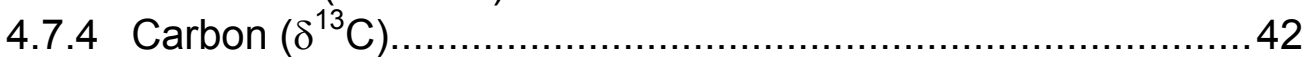

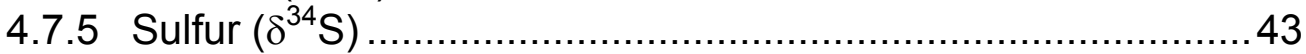

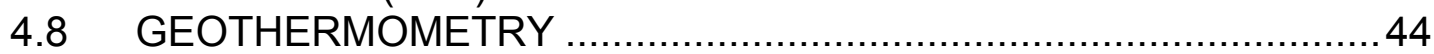

4.9 SYNTHESIS AND INTEPRETATION ........................................... 47

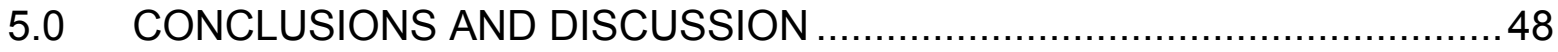

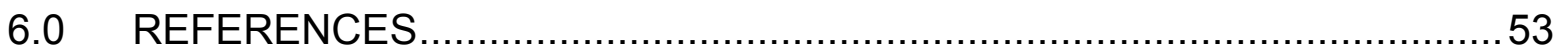




\section{APPENDICES}

APPENDIX 1.

Summary Geologic Log

page $\quad 60$

APPENDIX 2.

Core Run Log

pages $\quad 61-62$

APPENDIX 3.

Daily Drilling Report Log

pages $\quad 63-88$

APPENDIX 4.

Isotope Nomenclature

page $\quad 89$ 


\section{LIST OF TABLES}

Table

Page

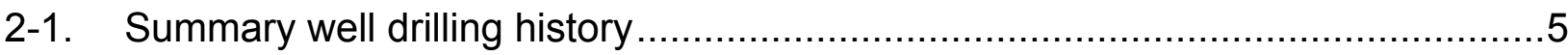

2-2. Original AmeriCulture State 2 well Construction …......................................

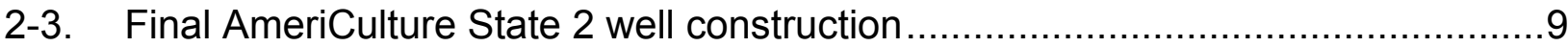

2.4. Geophysical and temperature logs of AmeriCulture State 2 well. .....................10

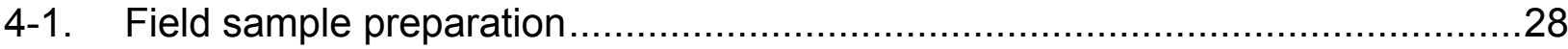

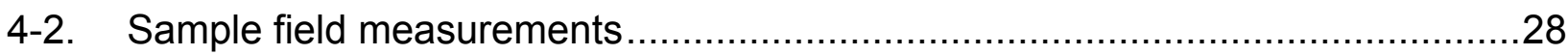

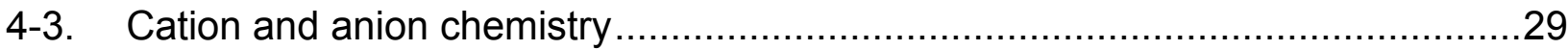

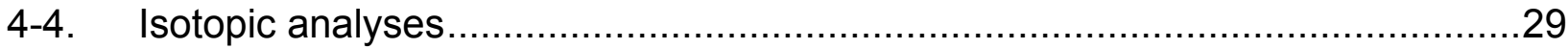

4-5. Geothermeter calculations for geothermal wells ........................................45

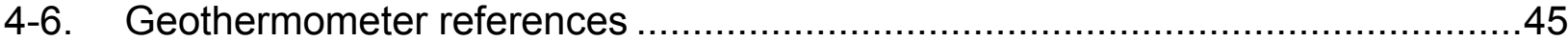




\section{LIST OF FIGURES}

Figure

Page

1-1. Location map of Lightning Dock geothermal area .........................................

3-1. Summary geologic unit well log of AM-2 with natural gamma log ....................12

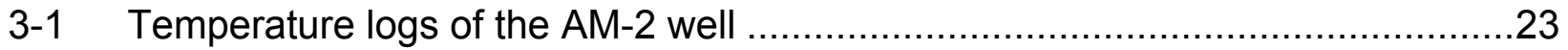

3-2 Temperature logs of the AM-2 well and the Steam Reserve 55-7 well...............24

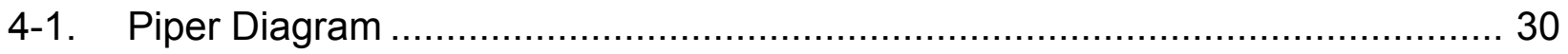

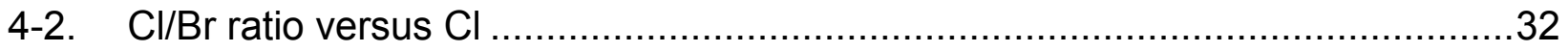

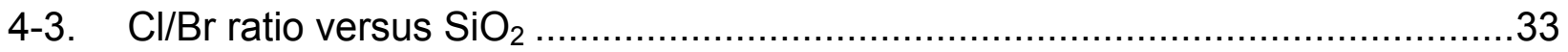

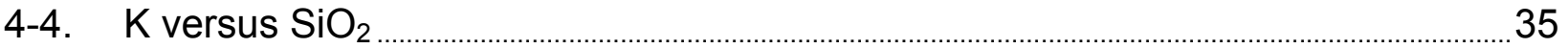

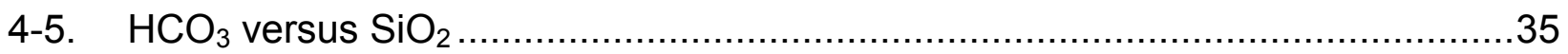

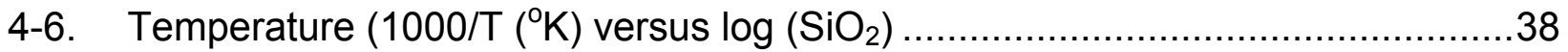

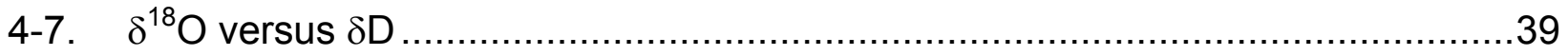

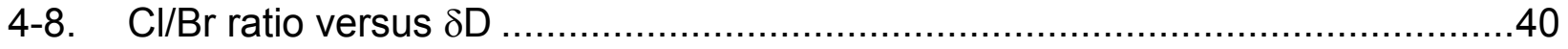

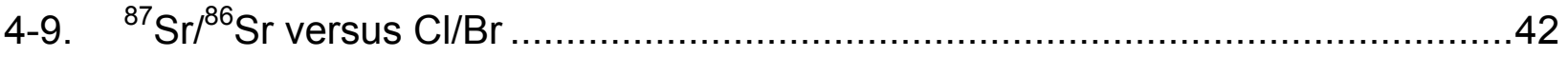

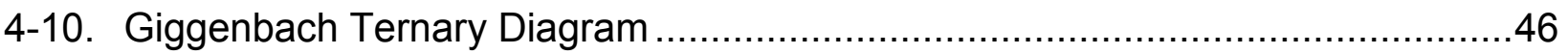




\section{$1.0 \quad$ INTRODUCTION}

\subsection{PURPOSE}

This report summarizes the GRED drilling operations in the AmeriCulture State 2 well with an overview of the preliminary geologic and geothermal findings, from drill cuttings, core, geophysical logs and water geochemical sampling.

\subsection{LOCATION AND SETTING}

The Lightning Dock KGRA is located in the Animas Valley, Hidalgo County, New Mexico near Cotton City (Figure 1-1). The area lies within the Mexican Highland section of the southern Basin and Range Province. The known productive portion of the KGRA is characterized by an elongate heat-flow anomaly that apparently represents outflow and a localized upflow zone of unknown characteristics at the southern end of the anomaly. A shallow northflowing plume underlies the tapered northern end of the heat-flow anomaly (Witcher, 2002). Production wells that tap the outflow plume are used to heat 30 acres of the Burgett geothermal greenhouses and the AmeriCulture Tilapia Farm.

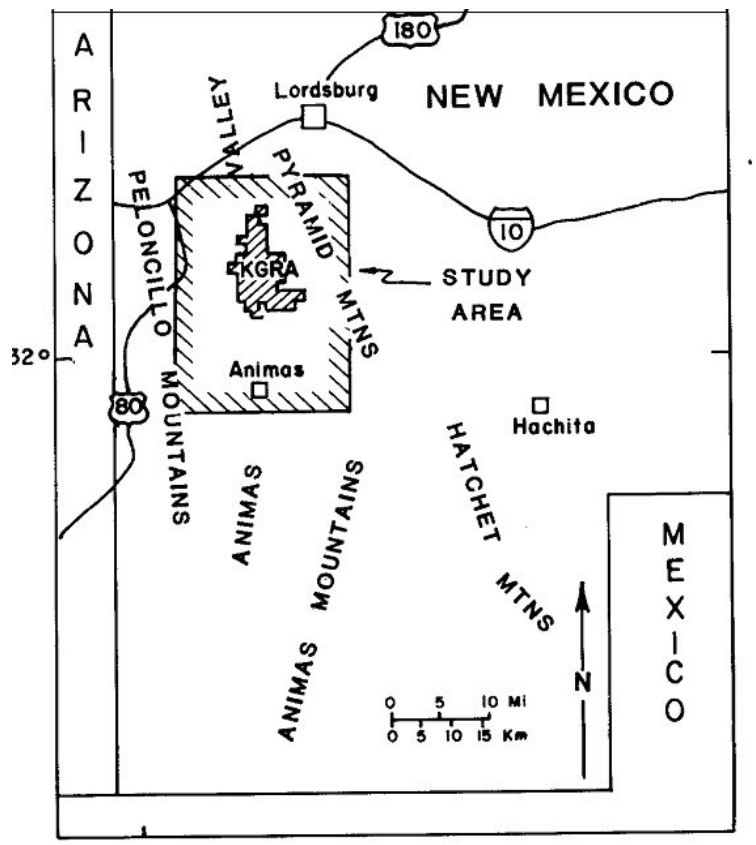

Figure 1-1. Location map of Lightning Dock geothermal area. 


\subsection{DRILLING AND SITE OPERATIONS}

\subsection{OBJECTIVES AND SCOPE}

The purpose for deepening the AM-2 well was to confirm hypothesized subsurface structure and stratigraphy and determine if inferred higher temperature $\left(\sim 300^{\circ} \mathrm{F}\right)$ outflows exist in the Upper Jurassic - Lower Cretaceous Bisbee Group and possibly the Pennsylvanian Horquilla Formation. Geologic and temperature logs in nearby AMAX 55-7 exploration hole indicated that potential existed for a deep outflow plume with temperatures around $300^{\circ} \mathrm{F}$ in the Lower Cretaceous rocks. Core drilling reached all planned stratigraphic targets by $1,687.5 \mathrm{ft}$ depth and the follow on reverse circulation rotary drilling continued the exploration into the Pennsylvanian Horquilla Formation at the planned TD of $2,100 \mathrm{ft}$.

\subsection{DRILL SITE LAYOUT AND WATER}

The AM-2 well site is within the Lightning Dock Known Geothermal Resource Area (KGRA) in the northeast quarter of the northeast quarter of section 7 , Township 25 South, Range 19 West, approximately $825 \mathrm{ft}$ from the east section line and $319 \mathrm{ft}$ from the north section line at an approximate elevation of 4,217 ft. The drill site is located on private surface, owned by AmeriCulture, Inc., adjacent and east of the AmeriCulture Geothermal Tilapia Farm complex. Access to the drill site is via a graded dirt road.

No dirt work was required to build a level and stable drilling pad. A backhoe was used to create small mud pits. Approximately $1,300 \mathrm{ft}$ of pipeline from an AmeriCulture water supply well provided water for all drilling operations to a large portable 20,000-gallon storage tank at the drill site. Overall layout provided for efficient water, mud, and equipment resupply, drilling operations, and well site geotechnical operations. 


\subsection{DRILLING EQUIPMENT}

Boart Longyear provided their wireline core-drilling unit LS 244EC. The drilling rig is basically a Longyear 44 size unit that is enhanced with computerized controls for a pneumatic top drive, draw works, and other advanced features. The final recovery of lost fish during coring and reaming of the hole to the 2,100 $\mathrm{ft}$ TD was done with the Lang LK-23 drill rig built in 1990. The LK-23 rig is a Drilltech DH-3 series platform that is equipped with a hydraulic tophead drive on a $52 \mathrm{ft}$ mast. Pullback is rated at $90,000 \mathrm{lbs}$, pulldown at 30,000 lbs, and rotary tork at 13,000 ft/lbs. A 900 cfm @350 psi compressor provides nominal compressor air capability. While over the AM-2 borehole, the LK-23 rig used rig and auxiliary air compressors in a reverse rotary drilling mode.

\subsection{WELL CONTROL}

In the event that pressured fluids, gas, or rapidly boiling or flashing superheated water entered the AmeriCulture well while drilling, several steps were taken to insure that well discharges would be controlled. Well control consisted of a well head with valved flow and kill line ports, a frac tank with 20,000 gallons of water on site, and the monitoring of bottom-hole temperatures (BHT) and blooie line temperatures. A rotating head was installed over the diverter. The kill line port was connected to the auxiliary water tank via a pump.

\subsection{HYDROGEN SULFIDE MONITORING}

Industry-standard, continuous-monitoring, hydrogen sulfide detectors, equipped with automatic visual and audio alarms, were installed at suitable locations to include the drill rig operators console, on the rig floor near the rotating head and diverter, and at the flow or blooie line discharge. Alarms were set to trigger visual alarms at 10 -ppm hydrogen sulfide and audio alarms at 15 ppm. A windsock was also installed at the location entry where it was visible to 
all site personnel. Self-contained breathing equipment was placed for emergency use at two different briefing area locations. The briefing areas were situated to provide one area that would be upwind of the hole at any given time. A warning and status sign was also placed at the entry to the drill site.

\subsection{WELL SITE GEOLOGY AND OPERATIONS MONITORING}

Well site geotechnical operations included making field geologic logs of core and cuttings and archiving core and cuttings for future reference or study. Currently, the core is stored at the AmeriCulture facility. Geophysical and temperature logs completed the geotechnical operations.

Operations monitoring included daily well history report log, daily cost tabulation. A summary daily well history report log is listed in Appendix 1. The daily report log was used to document footage per shift, blooie temperature measurements, all drilling activities, and materials used in drilling.

\subsection{DRILLING SUMMARY AND ANALYSIS}

Drilling and casing depths in this report are referenced to the ground surface. The deepening of the AM-2 borehole was done with wireline core drilling tools above $1,687 \mathrm{ft}$ depth feet depth and with reverse circulation rotary tools between 1,687 and 2,100 ft depth.

The GRED II project drilling and deepening of the existing $910 \mathrm{ft}$ deep AmeriCulture State 2 (AM-2) began on 13 August 2003 and reached total depth (TD) of 2,100 ft on September 28, 2003 (Table 2-1). Appendix 1 is a Summary Geologic Log of the AM-2 well. Appendix 2 is Core Run Log and Appendix 3 is a Daily Report Log with detail on drilling operations and events.

On August 11, 2003 Boart Longyear began rigging up the continuous wireline core drilling unit LS 244EC. This drilling rig has computerized controls for a pneumatic top drive and draw works. While cleaning the hole of thick mud from earlier rotary drilling, a $4 \frac{1}{2}$-inch drilling liner was hung inside a $123 / 4$-inch 
casing from the surface to $907 \mathrm{ft}$ depth without tag cementing the liner shoe in place. After preparing the wellhead with a diverter, $\mathrm{HQ}$ coring began at $906.5 \mathrm{ft}$ depth (GL elevation 4,217) on 13 August 2003. The first $40 \mathrm{ft}$ was cored with a "fast" rotation of 500 to $550 \mathrm{rpm}$. Due to the gritty nature of the rhyolite

Table 2-1 Summary well drilling history.

\begin{tabular}{|c|c|c|}
\hline DATE & DEPTH & ACTIVITY \\
\hline & $\mathrm{ft}$ & \\
\hline $8 / 11 / 2003$ & $\mathrm{n} / \mathrm{a}$ & Boart Longyear rigging up continuous wireline rig LS244EC. Install new well head flange. \\
\hline $8 / 12 / 2003$ & 906.5 & Cleaning and conditioning hole; run $41 / 2 \mathrm{HWL}$ inch liner; hung with no tag cement at shoe. \\
\hline $8 / 13 / 2003$ & 937.5 & Prepare well head and diverter, make up core tools, trip in hole, begin coring. \\
\hline $8 / 14 / 2003$ & 1117.5 & Core ahead, with high rpm (500 to 550$)$ rpm. Clean desanders. \\
\hline $8 / 15 / 2003$ & 1274.5 & Core ahead \\
\hline $8 / 16 / 2003$ & 1481.0 & Core ahead. Lost circulation Trip to replace core bit. \\
\hline $8 / 17 / 2003$ & 1529.0 & Trip tools back bottom; core ahead. Twist off. Fish. Trip in; core ahead; twist off. Fish. \\
\hline $8 / 18 / 2003$ & 1617.5 & Trip in; core ahead. Reduce rotation $550 \mathrm{rpm}$ to $300 \mathrm{rpm}$; lost circulation. \\
\hline $8 / 19 / 2003$ & 1687.5 & Core ahead; rods torque; trip out; check bit reamer shell; trip in; liner slips; twist off. \\
\hline $8 / 20 / 2003$ & 1687.5 & Fishing rods; drill liner slipped into hole to $123.3 \mathrm{ft}$ depth. \\
\hline $8 / 21 / 2003$ & 1687.5 & Fishing; wash hole and run Welenco camera survey. \\
\hline $8 / 22 / 2003$ & 1687.5 & Continue to wash hole and run Welenco camera survey. Start single 12-hour tower. \\
\hline $8 / 23 / 2003$ & 1687.5 & Fish out centralizers for drill liner. \\
\hline $8 / 24 / 2003$ & 1687.5 & Fish out more centralizers with missing setscrews. \\
\hline $8 / 25 / 2003$ & 1687.5 & Fish out more centralizers and biotite rhyolite cave from estimated $870 \mathrm{ft}$ depth. \\
\hline $8 / 26 / 2003$ & 1687.5 & Fish out more centralizers and more rhyolite. \\
\hline $8 / 27 / 2003$ & 1687.5 & Continue fishing; no recover. \\
\hline $8 / 28 / 2003$ & 1687.5 & No borehole activities. Rig computer controls inoperative. \\
\hline $8 / 29 / 2003$ & 1687.5 & No borehole activities. Rig computer controls inoperative. \\
\hline $8 / 30 / 2003$ & 1687.5 & Continue fishing; run mill at $1001.4 \mathrm{ft}$ to $1014.5 \mathrm{ft}$; run spear pull back $10,000 \mathrm{lbs}$, no fish. \\
\hline $8 / 31 / 2006$ & 1687.5 & Trip in magnet; no fish \\
\hline $9 / 1 / 2003$ & 1687.5 & Drill bridge 910 to $989 \mathrm{ft}$; wash down $1005 \mathrm{ft}$, mud up hole; lay down tools; demob core rig. \\
\hline $9 / 16 / 2003$ & 1687.5 & Rig up Lang rig \#LK-23 with top drive. Trip in washover bit and drill to $992 \mathrm{ft}$, top of fish. \\
\hline $9 / 17 / 2003$ & 1687.5 & Drill from 992 to $1045 \mathrm{ft}$ with washover bit. Condition hole. \\
\hline $9 / 18 / 2003$ & 1687.5 & Fish out liner, ream to $1187 \mathrm{ft}$. Trip out ream $117 / 8$ to $1175.5 \mathrm{ft}$ and tag HQ rods. \\
\hline $9 / 19 / 2003$ & 1687.5 & Grab HQ fish with overshot and trip out. \\
\hline $9 / 20 / 2003$ & 1687.5 & Continue to fish $\mathrm{HQ}$ tools, recover core barrel and core. \\
\hline $9 / 21 / 2003$ & 1687.5 & Ream hole to $1385 \mathrm{ft}$ (10 5/8 in tricone). \\
\hline $9 / 22 / 2003$ & 1687.5 & Ream hole to $1460 \mathrm{ft}$; run geophysical logs, and run $85 / 8$ in casing. \\
\hline $9 / 23 / 2003$ & 1687.5 & Continue casing; add cement basket; land casing with grout shoe. Tremie cement in hole. \\
\hline 9/24/2003 & 1687.5 & Cement bottom $1460 \mathrm{ft}$ to $1355 \mathrm{ft}$; WOC. Run AQ tremie annulus cement basket at $735 \mathrm{ft}$. \\
\hline $9 / 25 / 2003$ & 1455.0 & Tremie annulus cement; make up BHA; WOC. Trip in, tag cement grout shoe; drill out. \\
\hline $9 / 26 / 2003$ & 1770.0 & Drill ahead reverse circulation with water; steel cuttings bottom of core hole at $1687 \mathrm{ft}$ \\
\hline $9 / 27 / 2003$ & 1975.0 & Drill ahead reverse circulation with water. \\
\hline $9 / 28 / 2003$ & 2100.0 & Drill ahead reverse circulation with water; $77 / 8$ in hole to TD, trip BHA and lay down tools \\
\hline $9 / 29 / 2003$ & 2100.0 & Trip in air tube, airlift $20 \mathrm{gpm}$; W.L below $1400 \mathrm{ft}$, temp $137^{\circ} \mathrm{F}$; cut $85 / 8$ in casing $470 \mathrm{ft}$. \\
\hline $9 / 30 / 2003$ & 2100.0 & Release rig and demob. \\
\hline
\end{tabular}


ash flow tuff units and volcanoclastic sediments between $906.5 \mathrm{ft}$ and 1,334 ft depth, coring stopped several times to adjust the mud and clean the desanders. At 1,481 ft on August 16, 2003, the hole was tripped to replace the bit. The gauge of the inner cutting surface was worn out of specification. A new bit was tripped into the hole and coring resumed in the morning of August 17, 2003.

On the afternoon of 17 August 2003 drilling problems began to occur. At $1,527 \mathrm{ft}$, depth the drill rods twist off leaving $940 \mathrm{ft}$ of rods in the hole. The rods and core tools were recovered with a spear. The core in the tube was also recovered. After tripping to the bottom while circulating and washing, coring again commenced with another twist off at 1,529 ft depth. Again the rods, core tools, and core were retrieved. Coring resumed at 1,529 ft with a reduction in rotation from 550 to $300 \mathrm{rpm}$. At 1,559 ft, circulation was lost with no returns in the Lower Cretaceous Hell-to-Finish Formation, a limestone boulder conglomerate. On 19 August 2003 at 1,620 ft with lost circulation and no returns, the torque on the drill string became excessive. While tripping out of the hole to check the bit and reamer shell, the $41 / 2$-inch drill liner slipped into the hole. The rods were tripped back to bottom and disconnected and a spear was used to pull the $41 / 2$-inch liner back into place. Welded "ears" were placed at the surface on the liner to hold it in place. At $1,687.5 \mathrm{ft}$ the drill rods twisted off again. Only $1,180 \mathrm{ft}$ of drill rods were recovered above the twist off, leaving 508 feet of rods and core tools in the hole. On August 20, 2003, while attempting to trip a fishing spear into the hole, an obstruction was encountered at $890 \mathrm{ft}$. After tripping out with the fishing tools, the driller discovered that the $41 / 2$-inch liner had slipped into the hole. An impression tool located the top of the liner casing at $123.3 \mathrm{ft}$ depth. Later in the day, $778 \mathrm{ft}$ of $41 / 2$-inch liner was recovered. On August 21, 2003 another $100 \mathrm{ft}$ of $41 / 2$-inch liner was recovered, but an attempt to spear the core rods and core tools through the remaining liner in the hole was unsuccessful because of an obstruction at $887 \mathrm{ft}$ depth. The remainder of August 21 and 22, 2003 was spent conditioning the hole for camera survey and conducting multiple Welenco camera surveys. On August 23, 2003 the drill crew changes to one $12 \mathrm{hr}$ tower per day while attempting to recover fish in the hole. 
Between August 23, 2003 and August 31, 2003, eight centralizers were recovered leaving $29 \mathrm{ft}$ of $41 / 2$-inch liner with a shoe and two centralizers and $508 \mathrm{ft}$ of rods and core tools (core barrel, reamer shell, and bit) in the hole. On 1 September 2003, the Boart Longyear LS 244 EC was demobilized after conditioning the hole and drilling out a bridge of cave at 910 to $989 \mathrm{ft}$.

On 16 September 2003 the Lang Exploration Drilling Rig \#LK-23 top drive rotary rig was mobilized on to the site from Albuquerque. The next three days were spent clearing the hole of the remaining 4 1/2 -inch liner, drill rods and drill tools. However, during fishing operations, the open borehole from 908 to 1,203 ft was enlarged with an $117 / 8$-inch washover bit. All fish except half a centralizer, the core reamer shell, core bit, and a broken off part of a Bowen spear were recovered.

After the reverse-circulation drill string and supporting equipment had arrived, the hole was reamed ahead to $1,200 \mathrm{ft}$ on 21 September 2003 with a 10 $5 / 8$-inch full-face rock bit across the previous core-hole (HQ). Later in the day, a severe loss zone was encountered between 1,355 and 1,374 ft depth. However, the reverse-circulation ( $R C$ ) (air-assisted fluid lift inside a dual-wall drill pipe) drilling system allowed drilling ahead. About 7,000 gal of drilling mud was initially lost in this zone. After drilling ahead $3 \mathrm{ft}$ more, another 7,000 gal of drilling mud was lost. Drilling continued ahead to $1,385 \mathrm{ft}$ without returns. At $1,400 \mathrm{ft}$, circulation returned with full returns and the loss zone temporarily healed.

On 22 September 2003 at an interim depth of 1,460 ft, a solid formation suitable for setting casing was reached. A string of $85 / 8$-inch welded casing was run into the hole with a cementing shoe on the bottom and an annular cement basket welded at $753 \mathrm{ft}$ below ground level. The casing specifications are $28.58 \mathrm{lb} / \mathrm{ft}$ with a wall thickness of 0.322 inch and an internal pressure at minimum yield of 2,610 psi. The casing was landed on 23 September at a depth of $1,455 \mathrm{ft}$.

The casing was tag cemented through the cement shoe from $1,455 \mathrm{ft}$ up to the loss zone at 1,355 to $1,374 \mathrm{ft}$ with $300 \mathrm{gal}$ of cement. The $300 \mathrm{gal}$ volume 
of cement was enough to have theoretically cemented up the annulus to $1,255 \mathrm{ft}$. However, a fall-off in fluid returns to zero at the surface during cement pumping indicates that the cement had probably reopened the lost circulation zone at 1,355 to $1,374 \mathrm{ft}$.

A cementing tremie pipe was run down the annulus between the $85 / 8$ inch and 12 3/4 -inch casing on 24 September 2003. The annulus was cemented in stages up to about a depth of $492 \mathrm{ft}$ below ground level. On 25 September 2003, a $77 / 8$-inch drilling assembly was tripped into the hole and tagged good cement at $1 \frac{1}{2} \mathrm{ft}$ above the cement shoe. The cement shoe was drilled out and cement was drilled out to $1,455 \mathrm{ft}$ inside casing shoe. The 7 7/8inch hole was completed on 28 September to a total depth (TD) of 2,100 ft. An hour-long airlift pump test was performed on 29 September 2003 and showed an initial flow rate $50 \mathrm{gpm}$ at $154^{\circ} \mathrm{F}$ that dropped to $20 \mathrm{gpm}$ and $137^{\circ} \mathrm{F}$. The temperatures reflect cooling disturbance from lost circulation and drilling. The 8 $5 / 8$-inch casing was also cut off at $470 \mathrm{ft}$ depth below the surface on 29

September, 2003 and removed from the hole leaving an inside diameter of the 12 $3 / 4$-inch to $470 \mathrm{ft}$ depth.

\subsection{WELL COMPLETION}

Tables 2-2 show the initial completion of the AM-2 well prior to GRED II drilling operations over the hole. Table 2-3 adds the changes to the AM-2 well after GRED II drilling. The completed AM-2 well will allow perforating of the $12 \frac{3 / 4}{4}$ -inch casing with a mill to allow production of the productive outflow plume reservoir between 280 and $492 \mathrm{ft}$ depth. The $85 / 8$-inch casing below $470 \mathrm{ft}$ depth may require plugging or setting a packer to cap off deeper formations. Perforation and production of the 753 to $1,355 \mathrm{ft}$ interval with the $85 / 8$-inch casing with a pump set in the $123 / 4$-inch casing is another option for AM-2. The last option would produce from the $77 / 8$-inch open-hole at 1,455 to $2,100 \mathrm{ft}$ through the $85 / 8$-inch casing with the pump in the $12 \frac{3 / 4}{4}$-inch casing. However, the poor airlift test results make the later option highly unlikely. 
Table 2-2. Original AmeriCulture State 2 well construction.

\begin{tabular}{|c|c|c|c|c|c|c|}
\hline ITEM & HOLE & TOP & BOTTOM & CASING & WT & CEMENT \\
\hline & in & $\mathbf{f t}$ & $\mathbf{f t}$ & in & $\mathbf{l b s / f t}$ & $\mathbf{f t}^{\mathbf{3}}$ \\
\hline \hline rotary mud & 20 & 0 & 280 & & & \\
\hline surface & & 0 & 280 & 16 & 42 & \\
\hline cement & & 0 & 280 & & & 192 (pumped/shoe) \\
\hline rotary air & $143 / 4$ & 280 & 580 & & & \\
\hline intermediate & & 0 & 580 & $123 / 4$ & 36 & \\
\hline cement & & 520 & 580 & & & 33 (tag/shoe) \\
\hline rotary mud & $117 / 8$ & 580 & 910 & & & \\
\hline
\end{tabular}

Table 2.3. Final Americulture State 2 well construction.

\begin{tabular}{|c|c|c|c|c|c|c|}
\hline ITEM & HOLE & TOP & BOTTOM & CASING & WT & CEMENT \\
\hline & in & $\mathbf{f t}$ & $\mathbf{f t}$ & in & lbs/ft & ft $^{3}$ \\
\hline \hline rotary mud & 20 & 0 & 280 & & & \\
\hline surface & & 0 & 280 & 16 & 42 & \\
\hline cement & & 0 & 280 & & & 192 (pumped/shoe) \\
\hline rotary air & $143 / 4$ & 280 & 580 & & & \\
\hline intermediate & & 0 & 580 & $123 / 4$ & 36 & \\
\hline cement & & 520 & 580 & & & 33 (tag/shoe) \\
\hline rotary mud & $117 / 8$ & 580 & 910 & & & \\
\hline wirelinecore & $\mathrm{HQ}$ & 910 & 1687 & & & \\
\hline ream & $117 / 8$ & 910 & 1203 & & & \\
\hline ream & $105 / 8$ & 1203 & 1455 & & & \\
\hline intermediate & & 470 & 1455 & $85 / 8$ & 29 & \\
\hline cement & & 492 & 753 & & & 134 (basket/annulus) \\
\hline cement & & 1355 & 1455 & & & 40 (tag/shoe) \\
\hline rotary mud & $77 / 8$ & 1445 & 2100 & & & \\
\hline
\end{tabular}

\subsection{GEOPHYSICAL AND TEMPERATURE LOGGING}

The AM2 well was geophysically logged several times before the well was finally completed to current depth. Several temperature and gamma logs have been done on the hole at different stages in the history of the well (Table 2-4). Sandia National Laboratory (SNL), Albuquerque, New Mexico provided high quality equilibrium temperature logs in addition to a gamma log during the first phase of drilling of the AM-2 well to $910 \mathrm{ft}$. Welaco, a wireline geophysical firm 
from Bakersfield, California performed temperature and gamma logs during reaming operations and prior to setting an intermediate casing string to $1,460 \mathrm{ft}$ depth after Welaco had logged a nearby exploration borehole drilled by Lightning Dock Geothermal on an nearby Federal geothermal lease.

The SNL temperature logs were done with a conventional wireline thermocouple tool or with the temperature sensor and memory imbedded in the SNL Dewared core tube logger (CTL) tool. The Welaco temperatures were with conventional thermister wireline tools.

Table 2-4. Geophysical and temperature logs of the AmeriCulture State 2 well.

\begin{tabular}{|c|c|c|c|c|}
\hline LOG & DATE & INTERVAL ft & LOGGER & REMARKS \\
\hline \hline temperature & Dec-01 & $0-910$ & Sandia & original hole \\
\hline gamma & Dec-01 & $0-910$ & Sandia & original hole \\
\hline temperature & Sep-03 & $0-1455$ & Welaco & during ream \\
\hline gamma & Sep-03 & $0-1455$ & Welaco & during ream \\
\hline temperature & Dec-03 & $0-2100$ & Sandia & equilibrium ? \\
\hline
\end{tabular}

The gamma logs have a maximum sampling radius of about 1 to $2 \mathrm{ft}$ into the formation. A logging rate of about 30 feet per minute was used. As with temperature logs, the wireline signal is digitally converted into ASCII files for plotting, analysis, and interpretation.

The gamma log measures gamma radiation from naturally occurring uranium, thorium, and potassium. Because different rock types have different radioactivity levels, the gamma log is a very useful lithology correlation tool. For instance, shale and clay may have higher natural radioactivity than sandstone and sand.

\subsection{SITE CLEANUP}

Site cleanup of the AM-2 well pad at the end of drilling operations consisted of removing all trash and any oil contaminated soil to approved disposal sites. All equipment was removed from the site. 


\subsection{GEOLOGY AND THERMAL REGIME}

\subsection{SUMMARY GEOLOGIC LOG OF WELL}

The AmeriCulture State 2 (AM-2) well was initially drilled with both rotary air and rotary mud. Except for major zones of lost circulation in the lower part of the hole, cuttings quality was very good with both air and mud drilling (Witcher, 2002).

Figure 3-1 is a summary geologic log that is plotted alongside the Welaco gamma log. This short summary will begin in reverse order of deposition, contrary to typical geologic report convention, as this is the sequence encountered while drilling. The upper $645 \mathrm{ft}$ of the hole consists of alluvial basin fill deposits. From the surface down to $280 \mathrm{ft}$, the sandy gravel, clayey gravel, and minor clay deposits are largely unconsolidated. This unit probably represents uppermost Miocene to Quaternary mid and distal alluvial fan deposits mostly shed from the Pyramid Mountains to the east. At about 280 to $284 \mathrm{ft}$, thick and gravely orange gummy clay rests upon highly silicified sandy conglomerate. The silicified sandy conglomerate contains rounded clasts of andesite, ash flow tuff, and aphanitic rhyolite. Clasts in this volcanolitharenite are generally floating in a brick red and silicified silty to fine sand matrix. The highly indurated nature of the unit and clasts of ash flow tuff have resulted in an erroneous label for the unit in past drilling and geologic logs of wells at Lightning Dock. These logs call this unit "rhyolite or lithic tuff". The highly silicified nature of the unit is most intense between 284 and about $400 \mathrm{ft}$ depth. Below $400 \mathrm{ft}$, the unit is indurated, but not as strongly silicified. The sandy conglomerate from 284 to $570 \mathrm{ft}$ depth probably represents an earlier phase of basin fill sedimentation that is called the Gila Conglomerate in southwest New Mexico and southeast Arizona. The Gila Conglomerate at Lightning Dock may range in age from Oligocene to late Miocene.

At about $570 \mathrm{ft}$ the alluvial deposits, become generally coarse-grained with much less fine and medium sand and silt. The coarse deposits are found to a total depth of about $645 \mathrm{ft}$. The coarse unit may represent a basal unit 


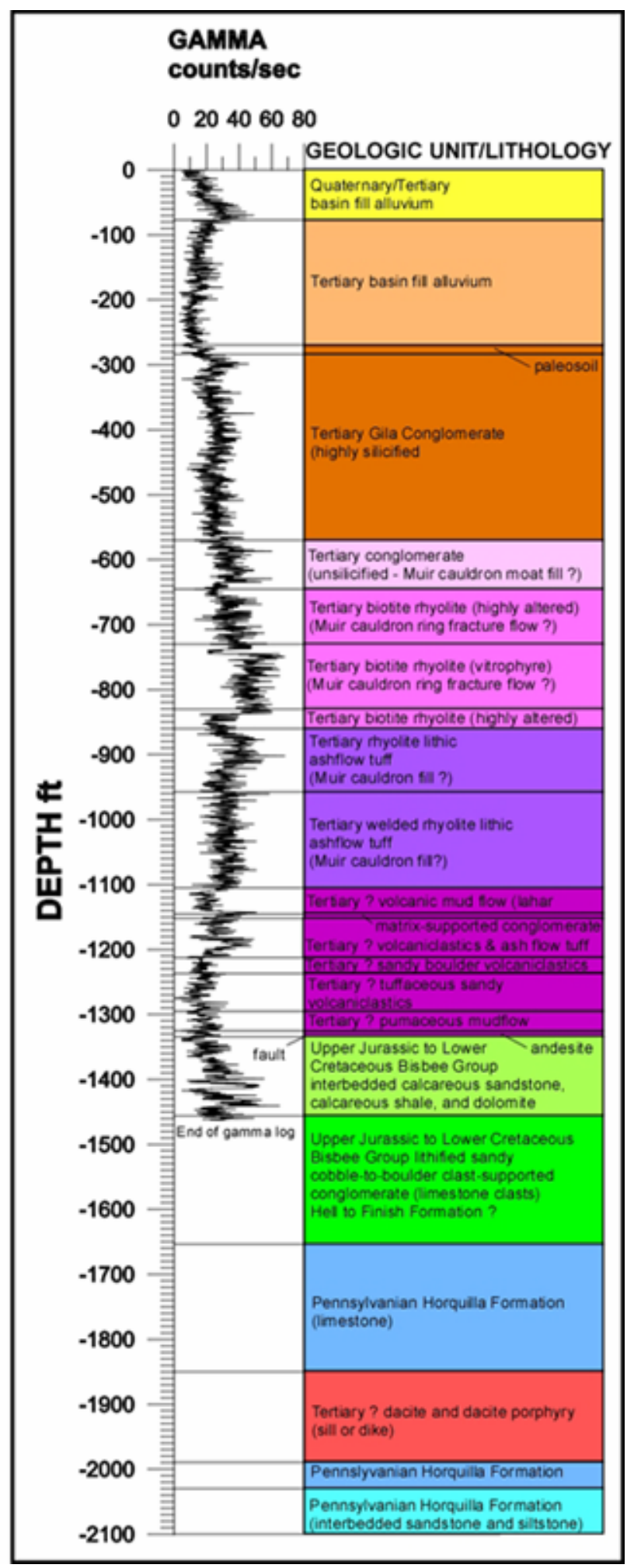

Figure 3-1. Summary geologic unit well log of AM2 with natural gamma log. 
of the Gila Conglomerate and record sedimentation associated with the initial extension in the Basin and Range Province or the unit may represent late sedimentary fill of the Muir Cauldron. In that case, these rocks may represent a post volcanism "ring fracture" moat fill.

At $645 \mathrm{ft}$ a biotite rhyolite was identified in drill cuttings. This unit could be a latite as no "megascopic" quartz phenocrysts are observed. The only other phenocrysts are plagioclase. No sanidine or "moonstone" was observed. This unit bottoms out at about $860 \mathrm{ft}$. The upper part of the unit from 645 to about 730 $\mathrm{ft}$ consists of white and apple green, altered rhyolite. Alteration preserved the biotite but no matrix textures. The apple-green color may represent reduced iron or a trace of microscopic chlorite or epidote. From 730 to $830 \mathrm{ft}$ the unit is not altered and displays some very diagnostic features. From 730 to $760 \mathrm{ft}$, a vitrophyre with perlitic texture is observed. The perlitic texture is pervasive even across devitrified zones developed around glassy cores. The perlitic texture shows more blocky elongated fractures (banded perlite) than arcuate or circular microcracks (classic perlite) (McPhie and others, 1993). In the lower part of this unit from 760 to 830 feet, the volcanic glass is either completely devitrified or absent. A few isolated spherulites, abundant lithophysae, and abundant extremely fine-grained, gray granophyric patches that appear to be lithophysae fill occur in a light brown aphanatic matrix. The lower part of the unit from 830 to $860 \mathrm{ft}$ closely resembles the upper part of the unit from 645 to about 660 feet and is altered. Because no eutaxitic textures or fiiamme are observed in the biotite rhyolite from 645 to $860 \mathrm{ft}$, the unit may represent a rhyolite flow (Cas and Wright, 1988). The abundant biotite, 3 to 10 percent, also places this unit in the volcanic episode associated with the Muir cauldron. Studies by Elston and others (1983) and McIntosh and Bryan (2000) indicated that siliceous rocks with abundant hydrous mineral phases such as biotite are mostly observed in the early phase of silicic volcanism in the region (such as the Muir Cauldron suite of volcanic rocks). Caving of the lower part of this unit during GRED drilling activities may have contributed to some of the drilling problems. 
Below the rhyolite, an ash flow tuff was drilled. While cuttings returns were poor due to lost circulation in the biotite rhyolite flow, sufficient returns allow a log and an interpretation. This unit, from about 860 to $958 \mathrm{ft}$ is a welded vitric crystal ash flow tuff with a matrix texture of devitrified granophyre. A ghost eutaxitic texture is clear and is outlined by abundant hematite in the matrix. About 10 to 20 percent of the rock contains crystals of plagioclase, quartz, and biotite. No sanidine or "moonstone" crystal fragments are positively identifiable under the binocular scope or hand lens. Total thickness of this unit is unknown. However, the tuff of Graham Well on the northern slopes of Lightning Dock Mountain ESE of the AM-2 well has similar attributes (Elston and others, 1976). The Tuff of Graham Well is an upper cauldron facies tuff of the Muir cauldron.

The thickest ash flow tuff unit was cored from 957.5 to $1,104.6 \mathrm{ft}$ depth. This unit is a light brown to buff heterolithic tuff that is partially welded with lapili mostly between $1 / 4$ to $1 / 2$-inch size. Pumice is altered and shows weak to moderate eutaxitic texture. It is likely that this unit is correlative with the tuff of Woodhaul Canyon, one of the lower cauldron fills of the Muir cauldron (Elston and others, 1976).

Between 1,104.5 and 1,325.9 ft depth a sequence of volcanic mudflow (lahars) and mud-supported tuffaceous volcanoclastic sand and gravel was cored. Clasts in the units range from felsite to basalt with andesite predominating. These units probably represent debris shed from mostly intermediate composition eruptive centers prior to the Muir cauldron silicic eruptions and caldera collapse and may be correlative with the Rubio Peak Formation or older andesite units of Eocene to Paleocene age. Core in this interval shows several fault zones. The most notable zones are from 1,169 to $1,175 \mathrm{ft}$ and 1,255 to $1,275 \mathrm{ft}$. The fault zone fractures are mostly healed with calcite and several thin zones of fault gouge were present in each zone.

From $1,325.9$ to $1,334 \mathrm{ft}$ depth, a porphyritic andesite flow was cored. The base of this unit is missing and cut by a fault at 1,334 ft. The andesite may be Eocene or upper Cretaceous-Paleocene age (Laramide). 
The Upper Jurassic to Lower Cretaceous Bisbee Group is encountered below the fault at $1,334 \mathrm{ft}$ depth. From 1,334 to $1,456 \mathrm{ft}$, the Bisbee Group is characterized by interbedded calcareous sandstone, calcareous shale, shale and dolomite. This interval is tentatively assigned to the Hell-to-Finish Formation. A fault zone at 1,392 to $1,397 \mathrm{ft}$ shows a $35^{\circ}$ to $40^{\circ}$ dip.

At 1,456 to $1,653 \mathrm{ft}$, a well-indurated or lithified sandy, cobble-to-boulder, clast-supported conglomerate was cored. Clasts consist mostly of Pennsylvanian limestone and some chert. This unit is assigned to the fanglomerate facies of the Hell-to-Finish Formation of the Bisbee Group. A fault zone dipping at about $69^{\circ}$ cuts this unit between 1,594 and 1,607 ft depth.

From 1,653 to $2,100 \mathrm{ft}$ the Pennsylvanian Horquilla formation was cored. The lower $70 \mathrm{ft}$ from 2,030 to 2,100 feet consists of fine gray sandstone to siltstone. The rest of the Horquilla is a fossiliferous gray to dark gray limestone (biomicrudite to intramicrudite) with some chert. Fusulinids were observed in some of the core. Between 1,850 and 1,990 ft, the Horquilla is intruded by a dacite to dacite porphyry dike or sill of probable Tertiary (Eocene) age.

\subsection{DISCUSSION AND SYNTHESIS OF GEOLOGY}

The uppermost shallow "bedrock" unit at Lightning Dock has previously been identified as "rhyolite". This unit is actually a silicified older Tertiary basin fill unit. This unit is correlated with the Gila Conglomerate, a catchall term for older indurated, alluvial sand and gravel packages that are found in southwestern New Mexico and southeastern Arizona. The Gila Conglomerate is actually a unit that should have group status rather than formation status and probably represents several formations which may be separated by major unconformities and have greatly different provenance for clasts among local sequences. In fact, not all Gila Conglomerate is accurately ascribed to represent older Tertiary graben or extensional basin fill of the Basin and Range Province. At the base of the Gila Conglomerate in the AM-2 well, a package of gravels with different provenance and gamma log signature overlies Tertiary volcanics. This lower unit may not be basin fill. Instead, the lower gravel may represent a remnant moat fill 
of the ring fracture zone of the Oligocene Muir cauldron of Elston and others (1983).

The base of the upper basin fill or top of the Gila Conglomerate contains a thick (about 4 to $5 \mathrm{ft}$ ) unit of gummy orange clay with clasts of gravel that may be interpreted as a "paleosol." This would indicate an unconformity and a local and stable structural high at Lightning Dock for a period of time during the late Miocene or early Pliocene. Regional gravity and aeromagnetic data back up this hypothesis. The Lightning Dock geothermal system occurs in this intra basin horst block.

Rhyolite and thicker ash flow tuff units encountered in the AM-2 well are probably Muir cauldron related extrusions. Several lines of evidence lead to this conclusion. First, the uppermost rhyolite is relatively rich in biotite, but poor in overall phenocryst percentage. Along with a general absence of lithic fragments, no quartz or sanidine is observed. Where plagioclase is observed, the phenocrysts are euhedral or sheared apart in place. Biotite is usually euhedral in hexagonal plates or smeared out in linear or curvilinear patches suggestive of forced flow or mechanical flow banding. A suite of silicic volcanic rocks blankets the region; but, these rocks represent ash flow tuffs erupted from distance caldera sources and have very little or no biotite and are generally relatively crystal and lithic rich (Elston and others, 1983 and McIntosh and Bryan, 2000). Non-euhedral or embayed crystal fragments in Rim Rock ash flow tuffs are usually represented by at least some sanidine ("moonstone") and quartz. The upper rhyolite also has vitrophryric zones that show perlitic textures. Where devitrification is prominent a few radial spherulitic textures are developed. In other areas of devitrification, lithophysae are well developed along with very finegrained granophyritic devitrification textures. At the base of the rhyolite, much "crackle breccia" occurs. This is interpreted as rhyolite flow autobrecciation rather than fracturing associated with a nearby fault. The rhyolite probably represents a late phase ring fracture zone flow. No typical ash flow tuff features such as eutaxitic texture or fiamme were observed. Hydrothermal alteration at the top and bottom of the rhyolite further implicates a flow rather than an ash flow 
tuff. Coupled with the fact that biotite is common, some phenocrysts appear sheared out (mechanical flow banding), and strong hydrothermal alterations exist on the top and bottom of the rhyolite, all pointing to a ring fracture rhyolite flow with an associated dike or dome complex. A correlation with a ring fracture eruptive unit, the rhyolite of Pyramid Peak, is provisionally given.

The upper ash flow tuff encountered in the AM-2 well may correlate to the tuff of Graham Well. The unit has quartz and has an unusual granophyric texture with hematite in the groundmass. Elston and others (1983) describe the tuff of Graham Well has having a strong hematite dusting in the groundmass.

The thick ash flow tuff below the Tuff of Graham Well is probably the tuff of Woodhaul Canyon and represents the main collapse cauldron fill of the Muir cauldron. The moderate thickness indicates a position at least in the Muir cauldron or outer ring fracture zone rather than an outflow facies.

While the Upper Jurassic to Lower Cretaceous Bisbee Group is inferred from poor geologic logs of the Steam Reserve 55-7 well, the AM-2 confirms the presence of the Hell-to-Finish Formation of the Bisbee Group. The Hell-to-Finish fanglomerates indicate a proximal location to a major WNW-striking late Jurassic to early Cretaceous normal fault of the Bisbee rift, a Mesozoic analog of today's Rio Grande rift. These faults were later reactivated during compression of the Laramide Orogeny with a reversed sense of motion.

The importance of the WNW trending basement structure is very apparent from a field reconnaissance of the mineralization along the western and southwestern slopes of Lightning Dock Mountain in the Pyramid Mountains ESE of the Lightning Dock thermal anomaly. All of the mineralized sites are within the basement trend highlighted by the aeromagnetic lineament. The first feature, a calcite vein zone (CVZ) with a width greater than $200 \mathrm{ft}$, has an orientation that is on strike with the thermal anomaly in the Animas Valley to the WNW. The Doubtful Mine site at the western base of Lightning Dock Mountain is a second site that contains light green fluorite mineralization in wide sheer or fault zone that trends NNW. Elston and others (1983) report fluid inclusion data that indicates 249 to $297^{\circ} \mathrm{F}$ temperatures and fall within the same range of 
temperatures that can be inferred from geothermometry and measured temperatures with today's thermal anomaly at the KGRA. The CVZ southeast of the mine on the southwestern slopes of Lightning Dock Mountain has the following paragenesis:

a) early white coarsely crystalline calcite that is weakly banded.

b) brecciation, deposition of black manganese minerals and dark manganiferous calcite.

c) brecciation, deposition of gray and white-banded calcite.

d) brecciation, silica quartz deposition in breccia spaces and along calcite cleavage planes.

e) brecciation, and calcite dissolution in silicified zones to create "honeycomb" spaces that are filled with euhedral quartz. The dissolution cavities frequently have the shape of rhombohedral calcite cleavage fragments.

Elston and others 1983) describe the paragensis of the Doubtful Mine, which contains fluorite. No fluorite was observed during the reconnaissance of the CVZ. Propylitic alteration is apparent in the tuff of Woodhaul Canyon country rock that surrounds the CVZ. The overall dimensions and character of the Doubtful Mine and the CVZ may provide a clue as to the dimensions and character of the upflow zone for the Lightning Dock KGRA thermal anomaly. The main upflow may be concentrated in a relatively small area and be characterized by repeated episodes of mineralization and fracturing. As indicated by the CVZ, a particular fault may not host the upflow zone.

Elston and others (1983) show outcrops in the Threemile Hills in an area south of the KGRA as the Mojado and U-Bar Formations. A field investigation of outcrops discovered that these units are probably not autochthonous. While exposures are poor, the site identified as the Mojado Formation actually has lithology more typical of the Hell-to-Finish Formation. The unit is probably allochthonous and has no systematic bedding orientation. Boulders up to 1-to-4 $\mathrm{ft}$ across of Pennsylvanian Horquilla limestone, Hell-to-Finish sandy chert conglomerate, and Mojado (?) indurated quartz sandstone are all jumbled up on 
a low relief, poorly exposed hill slope beneath ash flow tuffs of the Rimrock Mountain sequence. The outcrop identified a U-Bar Formation is poorly exposed along the Old Lordsburg road. Again, the exposures of U-Bar may not be in place. The outcrop shows abundant calcite-healed fracturing and weak marblization and no consistent orientation or bedding strike and dip. Again, ash flow tuffs of the Rimrock Mountain sequence overlie the outcrops. These outcrops could be interpreted as landslide deposits that are older than the Rimrock Mountain sequence.

A field investigation of Table Top Mountain south of the KGRA thermal anomaly and northwest of the Threemile Hill area reveals that this outcrop consists of Gila Conglomerate (?) and has been hydrothermally silicified. This outcrop is similar to lithology from the AM-2 well from 280 to $400 \mathrm{ft}$ depth. Most curiously, Table Top Mountains is teardrop shaped and has the same approximate size, shape, and orientation as the $800-$ to- $1000 \mathrm{~mW} / \mathrm{m}^{2}$ heat flow contour closure at the Lightning Dock KGRA. The shape and size may not be a coincidence. In fact, Table Top Mountain may represent the fossil expression of a former hydrothermal outflow plume from a late Miocene or early Pliocene geothermal system. Local Neogene uplift of the area allowed erosional stripping of unaltered gravels, leaving the hydrothermally silicified gravels of Table Top Mountain preserved as an inselberg. Also of interest, Table Top Mountain has an analogous tectonic setting to the Lightning Dock KGRA. In fact, another WNW trending structure zone slices this area of the Muir cauldron fracture zone (Lawton, 2000; and Bayona and Lawton, 2000). The area lies within the accommodation zone between the upper and lower Animas grabens and regional gravity data shows the area to be structurally high. Available temperature gradient information indicates enhanced heat flow. None of the temperature gradient holes is located properly to assess whether or not an active geothermal systems exists beneath Table Top Mountain today.

Field investigation of the Pleistocene "Animas" fault shows that only about 6 to $8 \mathrm{ft}$ of displacement have occurred north of the KGRA. In a discussion of the fault by Stephen Wells in Elston and others (1983), a maximum of $16 \mathrm{ft}$ relief is 
reported for the fault. The scarp breaks a piedmont fan surface with Stage 2 to Stage 3 caliche development with a late Pleistocene age (Gile and others, 1981). The relatively steep profile of the scarp qualitatively indicates an age between about 100 and $10 \mathrm{ka}$. This fault appears to indicate only one or two displacement events. The lack of a major gravity geophysical expression indicates that this fault is not a major bounding fault of the Animas graben. The fault is a young incipient structure. The eastward embayment of low gravity across the fault north of the KGRA backs this conclusion (O'Brien and Stone, 1983 and 1984). The major graben structures are east of this fault and have not been active in the Quaternary. The importance of the "Animas" Pleistocene fault for geothermal conditions in the KGRA is not clear. Because the fault ends at thermal anomaly, tectonism may have reopened or enhanced fracture permeability in the upflow zone. Fault tips are favorable sites for enhanced fracture permeability.

Elston and others (1983) argue that a northeast-trending structure plays a major role in providing geothermal fluids into the Lightning Dock KGRA where the northeast structure intersects the ring fracture zone of the Muir cauldron. Temperature and oxygen isotope data do show a trend that supports the Elston and others (1983) argument. Gas studies of fluids at Lightning Dock and the Animas Valley by Norman and Bernhardt (1982) also show the same trend. Elston and others (1983) further argue that the northeast trend is a crustal structure or weakness that allows leakage of basaltic magmas to the surface and shallow crust. Basaltic flows near Animas and Rodeo, which are northeast of the basaltic volcanic field of the San Bernardino Valley in Arizona, suggest the possibility of northeast-trending structure with an imbedded magmatic heat source. Another interpretation is also valid that is not discussed by Elston and others (1983) or Norman and Bernhardt (1982). The area of discussion lies along the structurally high accommodation zone, separating the upper and lower Animas grabens. South flowing ground water in the deeper alluvial fill of the upper Animas graben is forced upward over the northeast-trending accommodation zone by structurally high bedrock. The older and deeper source waters will have slightly higher temperature, somewhat lighter oxygen stable 
isotope $\left({ }^{18} \mathrm{O} /{ }^{16} \mathrm{O}\right)$ ratios, and gas compositions much different than shallow and young basin-fill waters. These waters probably represent upwelling older alluvial basin water rather than leakages of deep-seated magma-heated geothermal water in bedrock along a hypothetical northeast-trending fault.

Elston and others (1983) suggest that a basaltic magma in the deep subsurface of the region along the northeast-trending structure provides a heat source for the Lightning Dock geothermal system. While accommodation zones are favorable sites for basaltic volcanism in rift settings, this hypothesis is highly unlikely as basaltic magmas in a continental setting are not of sufficient volume and intrusive duration for magma replenishment to provide a sustained heat source for a hydrothermal system (Smith and Shaw, 1975; and Jaeger, 1964).

O'Brien and Stone (1982) present a lithology log for the Cockrell Pyramid well. The Gila Conglomerate overlies Tertiary volcanic rocks at 1,890 ft depth. Tertiary volcanics are at $645 \mathrm{ft}$ depth in the AM-2 well. Therefore, a fault with more than $1,200 \mathrm{ft}$ of throw has displaced the geologic section between the two wells. One of the most interesting features of the Cockrel Pyramid log is the thick "Tertiary" volcanic section from 1,890 to $5,795 \mathrm{ft}$ depth. Two things are striking. First is the fact that the volcanic section overlies Mississippian rocks instead of Pennsylvanian or Cretaceous rocks, indicating Laramide (Late Cretaceous to Eocene) inversion of structure along the WNW structure zone when compared to the Steam Reserve 55-7 well. Second, the column of Tertiary volcanic rocks is very thick. A thick Eocene (Laramide) sequence of andesite is observed in the Peloncillo Mountains to the west between Granite Gap and Road Forks and in the northern Pyramid Mountains. Volcanics in the Cockrell Pyramid well may be dominated by the Eocene andesite sequence. Tectonic inversion would support a thick section of andesite. On the other hand, much of the sequence may be represented by the Rimrock tuffs and Muir cauldron affinity volcanics. 


\subsection{TEMPERATURE LOGS AND INTERPRETATION}

Several temperature logs have been run on the AM-2 well at various stages of the well history. Figure 3-2 compares the disequilibrium Welaco log on 20 September, 2003 with equilibrium logs taken in December 2001 and 2003. The difference in temperatures for the upper $500 \mathrm{ft}$ for the two equilibrium logs is believed to be the affect of cooling on the 2003 log by convection in the borehole that is aided by the $85 / 8$-inch casing that is open to the formation below $1,455 \mathrm{ft}$ rather than a cooling of the shallow reservoir. The Welaco log shows much lower temperatures because it represents a disequilibrium log before the well had recovered from cooling disturbance from drilling. A very minor temperature deviation is observed in the December $2003 \log$ of AM-2 at about 1,203 ft. This could be a very small-lost circulation zone. If so, it correlates with the deep outflow zone observed in the Steam Reserve 55-7 well (Figure 3-3).

Clearly, the AM-2 well does not show an important reservoir below the shallow outflow plume reservoir. After the temperatures roll over the temperature gradient is largely linear. Apparently none of the fault zones encountered below $1,150 \mathrm{ft}$ are conducting up flow of hot water and the major lost circulation zones between 1,300 and 1,400 ft not appear to be transmitting hotter water upward or allowing down flow of cooler water.

An hour long air-lift pump test was performed on 29 September, 2003 and showed a maximum flow rate $50 \mathrm{gpm}$ which dropped to near $20 \mathrm{gpm}$ while the water level fell below $1,400 \mathrm{ft}$ depth. After the well fully recovered, static water levels average around $54 \mathrm{ft}$, similar the those in the Steam Reserve 55-7 well; but higher that the nearby AM-1 production well which averages around $70 \mathrm{ft}$.

The Lower Cretaceous Hell-to-Finish and the Pennsylvanian Horquilla Formations apparently do not have enough permeability beneath the AM-2 site to act as reservoirs for outflow of fluids. Equilibrium temperatures are only slightly higher than the temperatures observed in the shallow outflow plume reservoir. 


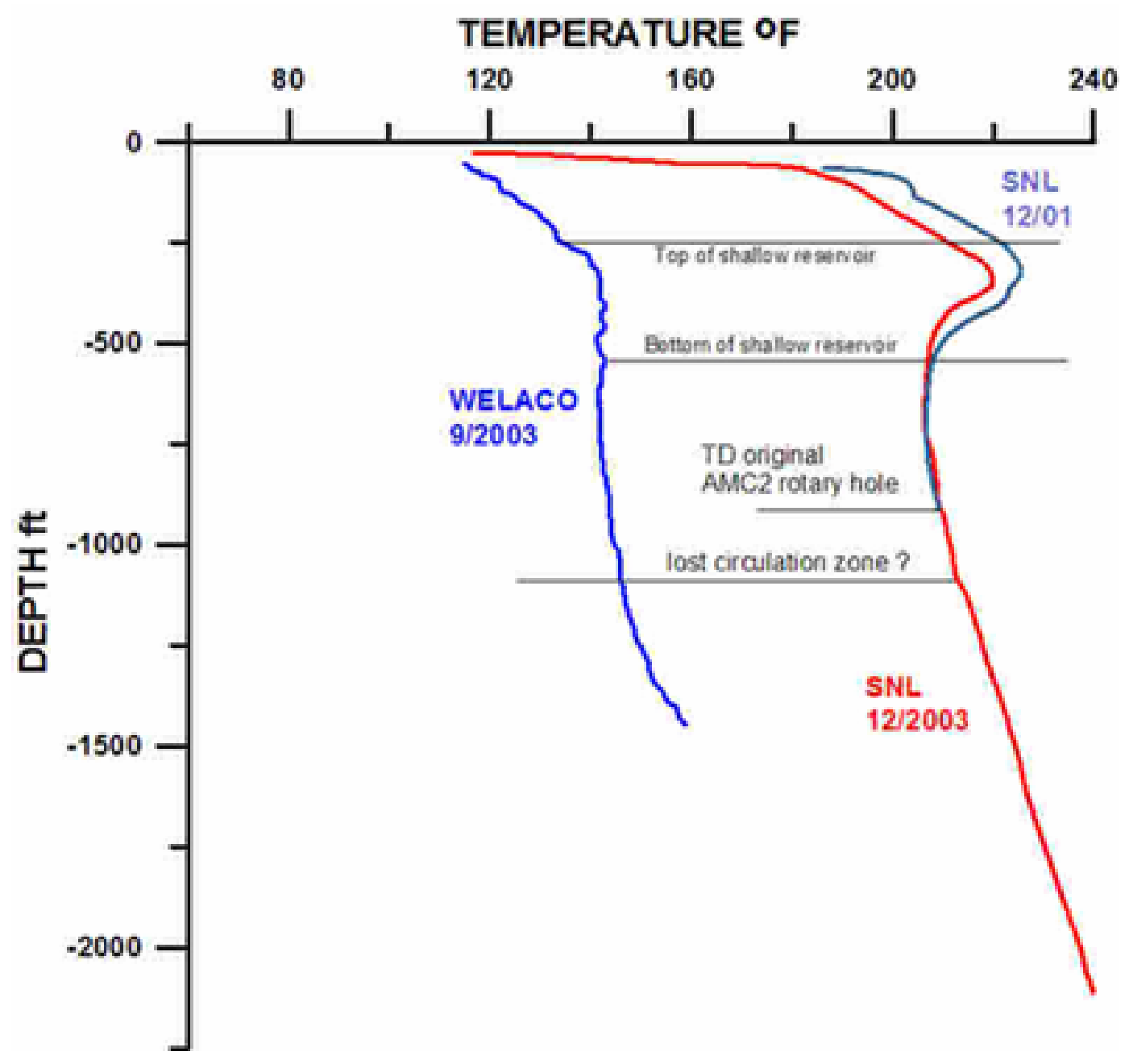

Figure 3-2. Temperature logs of the AM-2 well. 


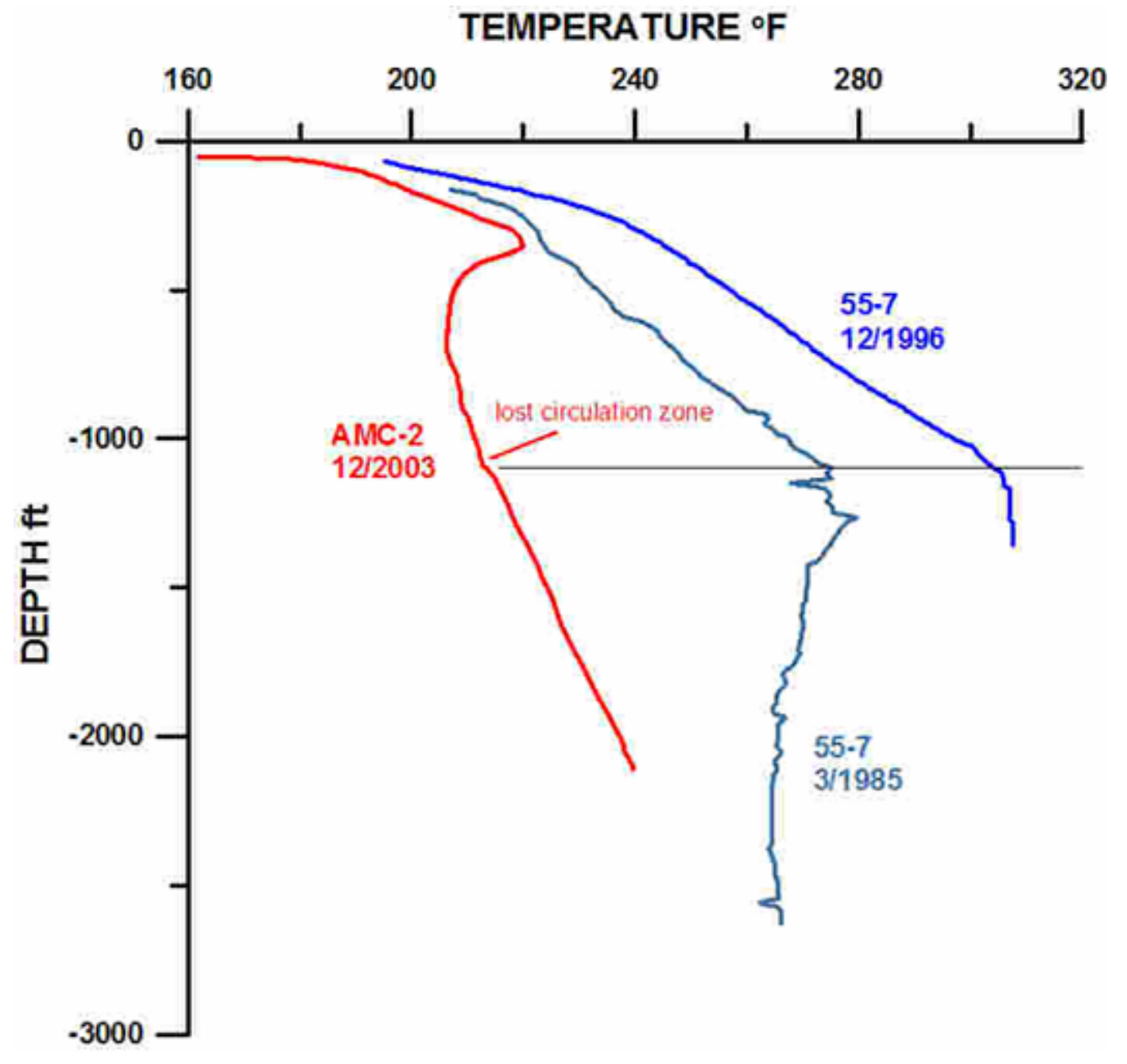

Figure 3-3. Temperature logs showing the relationships between the AM-2 well and the Steam Reserve 55-7 well prior to thermal equilibrium and after thermal equilibrium. 


\subsection{GEOCHEMISTRY}

\subsection{PURPOSE}

Groundwater chemistry in geothermal wells at the Lightning Dock KGRA is investigated to in order to obtain information on possible flow paths (such as the nature of the upflow zone host), deep reservoir hosts, mixing, subsurface boiling, and deep reservoir temperature.

\subsection{PREVIOUS STUDIES}

The main aqueous geochemical studies performed at the Lightning Dock KGRA area include include Cunniff and Bowers (1988), Dellechaie (1977), Swanberg and others (1977), Logsdon (1981), Norman and Bernhardt (1982), O'Brien and Stone (1982) Elston and others (1983), Hawley and others (2000), and Hibbs (2000). Logsdon (1981) and Elston and others (1983) discuss a mixing model that predicts a deep reservoir of $250{ }^{\circ} \mathrm{C}$. Logsdon (1981), Elston and others (1983), and Norman and Bernhardt (1982) use groundwater chemistry and groundwater gases to infer a deeply penetrating, southweststriking structural zone host for a deep high-temperature reservoir and possibly basaltic magma southwest of the area of hot wells (the heat-flow anomaly). Logsdon (1981) and Elston and others (1983) argue for a $165{ }^{\circ} \mathrm{C}$ shallow reservoir consisting of mixture of 25 percent deep geothermal fluids and 75 percent cold groundwater.

\subsection{APPROACH}

The chemical and isotopic character of the geothermal waters is related to flow path length or age of water since recharge, climate and geographic area of recharge, the type of rocks that host water flow and react chemically with the water, and temperature. The processes of cation exchange, hydration reactions, mixing, dissolution, precipitation, and boiling can all play specific roles.

Geochemical fingerprints comprise two general categories. The first uses the ratios of conservative ions such as chloride $(\mathrm{Cl})$, boron $(\mathrm{B})$, bromide $(\mathrm{Br})$, and 
lithium ( $\mathrm{Li}$ ). These ions are highly soluble or conservative and are, therefore, unlikely to be involved in precipitation of minerals and can be applied to study mixing, evaporative (boiling) concentration, and dissolution of salts (Hem, 1985).

A second category involves the isotopic characteristics of the water and dissolved chemical constituents. Isotopic information is useful to characterize temperature, recharge source and paleoclimate, age since recharge, and the type of rock that hosts water flow (Mazor, 1997). Isotopic signatures, in conjunction with conservative dissolved ions, can also be used to investigate mixing of waters with different flow domain heritage or to delineate other geochemical processes such as boiling.

Aqueous geochemical models that define chemical and isotopic equilibrium or saturation indices with solid mineral phases provide additional interpretative tools to characterize chemical evolution and sources (Bethke, 1996).

Several isotopic systems when combined with solute chemistry, allow cross checking of results and interpretations. The first and most commonly used system uses fractionation ratios of natural stable isotopes such as oxygen $\left({ }^{18} \mathrm{O} /{ }^{16} \mathrm{O}\right)$, hydrogen $\left({ }^{2} \mathrm{H} / \mathrm{H}\right)$, carbon $\left({ }^{13} \mathrm{C} /{ }^{12} \mathrm{C}\right)$, and sulfur $\left({ }^{34} \mathrm{~S} /{ }^{32} \mathrm{~S}\right)$ (Clark and Fritz, 1997). Recharge source and timing, temperature, rock-water reactions, organic processes, and evaporation can have an important impact on these ratios. In addition, the sulfur and carbon isotopes may point to specific geologic formations as chemical sources.

The second isotopic approach uses radiogenic stable-daughter isotope ratios such as the strontium $\left(\mathrm{Sr}\right.$ ) system of ${ }^{87} \mathrm{Sr} /{ }^{86} \mathrm{Sr}$ (Banner and others, 1989; Johnson and DePaolo, 1994). The Sr system is useful to fingerprint the flow path and type of rock that the groundwater has predominantly encountered. The $\mathrm{Sr}$ isotope systematics can provide a proxy for the ultimate source(s) of calcium $(\mathrm{Ca})$ and potassium $(\mathrm{K})$ in mixed geothermal waters.

Four samples were taken from a range of geothermal wells found in different areas of the Lightning Dock KGRA as defined by the heat flow anomaly. In addition to field sample filtering and preservation, the $\mathrm{pH}$, and conductance 
were immediately determined. High-temperature $\left(>90 \quad{ }^{\circ} \mathrm{C}\right)$ samples were retrieved at discharge ports in the greenhouse-heating loop of each production well so that cooled and unboiled samples could be obtained. Analysis of dissolved ions included:

$\mathrm{Na}, \mathrm{Ca}, \mathrm{Mg}, \mathrm{Sr}, \mathrm{K}, \mathrm{HCO}_{3}, \mathrm{SO}_{4}, \mathrm{Cl}, \mathrm{SiO}_{2}, \mathrm{Br}, \mathrm{Li}, \mathrm{B}, \mathrm{F}$, and TDS

Samples taken for chemistry were also isotopically analyzed for:

$$
{ }^{18} \mathrm{O} /{ }^{16} \mathrm{O},{ }^{2} \mathrm{H} / \mathrm{H},{ }^{13} \mathrm{C} /{ }^{12} \mathrm{C},{ }^{34} \mathrm{~S} /{ }^{32} \mathrm{~S} \text {, and }{ }^{87} \mathrm{Sr} /{ }^{86} \mathrm{Sr} \text {. }
$$

Charge and mass balance were used to evaluate the quality of the results from sampled fluids (Reed and Mariner, 1991).

An integrated approach of traditional solute chemistry and isotopic systematics was employed. Water temperature and hydrogeologic information complemented geochemical and isotopic interpretations. Data interpretation focused on flow path sources, mixing, possible subsurface boiling, and chemical geothermometry.

\subsection{METHODS}

Sampling was accomplished after allowing the discharge sampling point to flow for at least 15 minutes. A 5-gallon (19.2 liter) plastic pail (well rinsed with the sample water) was used to take a grab sample. Temperature was determined using a digital thermometer. Aliquots were taken for determination of $\mathrm{pH}$ with an Oakton $\mathrm{pH} 10$ series meter, and conductivity using an Oakton Con5 Acorn series meter. Alkalinity was determined using a Hach digital titrator. A 50 $\mathrm{mL}$ sample was pipetted into a beaker with a magnetic Teflon stirring rod and placed on a "homemade" portable field magnetic stirrer. A pre-measured packet of Bromcresol Green-Methyl red reagent was added and the solution was titrated by drops with $0.1600 \mathrm{~N} \mathrm{H}_{2} \mathrm{SO}_{4}$ until the color changed to pink. The amount of acid required times 2 gives a direct reading of $\mathrm{mg} / \mathrm{L}$ total alkalinity (as $\mathrm{CaCO}_{3}$ ).

Six water samples were collected for laboratory analysis. The ${ }^{2} \mathrm{H} /{ }^{1} \mathrm{H}$ and ${ }^{18} \mathrm{O} /{ }^{16} \mathrm{O}$ samples were collected in amber glass bottles with septum caps, rinsed with sample water. All other samples were collected in high-density polyethylene bottles (HDPE), which were washed with soap, rinsed with tap water to remove the soap, and rinsed three times with distilled/deionized water (DDIW). The last 
rinse was left in the bottles and emptied just prior to sampling. After the preceding wash and rinse, the ${ }^{87} \mathrm{Sr} /{ }^{86} \mathrm{Sr}$ sample bottles were placed in a 10 percent ultra pure nitric acid bath for a minimum of 24 hours, followed by three additional rinses with DDIW. Filtration was accomplished on site with a 0.45micron filter and vacuum flask. A "homemade" vacuum pump, constructed from a small marine bladder pump with cigarette lighter power supply, was connected to the vacuum flask for rapid and efficient filtering. Table 4-1 shows the amounts and treatments of the samples collected.

Table 4-1. Field Sample Preparation.

\begin{tabular}{|l|l|l|l|}
\hline SAMPLE & AMOUNT & FILTERED & TREATMENT \\
\hline \hline anions & $250 \mathrm{ml}$ & yes & none \\
\hline cations & $250 \mathrm{ml}$ & yes & acidified to $\mathrm{pH}<2$ with $\mathrm{HCl}$ \\
\hline${ }^{2} \mathrm{H} /{ }^{1} \mathrm{H}$ and ${ }^{18} \mathrm{O} /{ }^{16} \mathrm{O}$ & $60 \mathrm{ml}$ & no & none \\
\hline${ }^{13} \mathrm{C} /{ }^{12} \mathrm{C}$ & $250 \mathrm{ml}$ & no & sodium azide \\
\hline${ }^{34} \mathrm{~S} /{ }^{32} \mathrm{~S}$ & $1 \mathrm{~L}$ & yes & BaCl w/ BaSO ${ }_{4}$ filtrate \\
\hline${ }^{87} \mathrm{Sr} /{ }^{86} \mathrm{Sr}$ & $250 \mathrm{ml}$ & yes & acidified to $\mathrm{pH}<2$ with ultrapure $\mathrm{H}_{2} \mathrm{NO}_{3}$ \\
\hline
\end{tabular}

\subsection{DATA}

Field measurements taken during sampling are shown in Table 4-2. Temperatures represent wellhead discharge. The AM4 sample has a much lower temperature and a higher alkalinity than the other wells sampled.

Table 4-2. Sample Field Measurements.

\begin{tabular}{|c|c|c|c|c|c|c|c|}
\hline SAMPLE & SITE & TEMP & TEMP & pH & COND & $\begin{array}{c}\text { ALK- } \\
\text { HCO3 }\end{array}$ & DATE \\
\hline & & ${ }^{\circ} \mathbf{F}$ & ${ }^{\circ} \mathbf{C}$ & & & & \\
\hline \hline AM1 & Burgett \#1 & 208 & 97.8 & 8.26 & 2090 & 172 & $1 / 16 / 2003$ \\
\hline AM2 & Burgett \#C & 224 & 106.7 & 7.10 & 1932 & 178 & $1 / 16 / 2003$ \\
\hline AM3 & Burgett \#6 & 224 & 106.7 & 7.47 & 1515 & 174 & $1 / 16 / 2003$ \\
\hline AM4 & AmeriCulture Fed & 118 & 47.8 & 7.47 & 1661 & 316 & $1 / 16 / 2003$ \\
\hline
\end{tabular}


Cation and anion chemistry is shown in Table 4-3. Samples, AM1, AM3, and AM2 all have similar chemistry; however, chloride $(\mathrm{Cl})$, silica $\left(\mathrm{SiO}_{2}\right)$, fluoride $(\mathrm{F})$, sodium $(\mathrm{Na})$, sulfate $\left(\mathrm{SO}_{4}\right)$ and potassium $(\mathrm{K})$ show slight systematic changes in concentrations.

Table 4-3. Cation and Anion Chemistry.

\begin{tabular}{|c|c|c|c|c|c|c|c|c|c|c|c|c|c|c|c|c|}
\hline SAMPLE & SITE & $\mathbf{p H}$ & $\mathbf{N a}$ & $\mathbf{K}$ & $\mathbf{C a}$ & $\mathbf{M g}$ & $\mathbf{S r}$ & $\mathbf{C l}$ & $\mathbf{S O}_{4}$ & $\mathbf{H C O}_{3}$ & $\mathbf{F}$ & $\mathbf{S i O}_{2}$ & $\mathbf{B}$ & $\mathbf{B r}$ & $\mathbf{L i}$ & $\mathbf{T D S}$ \\
\hline \hline AM1 & Burgett \#1 & 8.40 & 377 & 22 & 22 & 0.1 & 1.4 & 98 & 543 & 101 & 9.8 & 144 & 0.4 & 0 & 1 & 1180 \\
\hline AM2 & Burgett \#C & 8.10 & 325 & 15 & 24 & 0.1 & 1.2 & 89 & 493 & 113 & 8.9 & 113 & 0.4 & 0 & 0.5 & 1050 \\
\hline AM3 & Burgett \#6 & 8.00 & 314 & 15 & 24 & 0.2 & 1.2 & 86 & 482 & 113 & 8.3 & 111 & 0.4 & 0 & 0.6 & 1030 \\
\hline AM4 & AmeriCulture Fed & 8.00 & 314 & 11 & 44 & 0.8 & 1.2 & 90 & 444 & 195 & 5.6 & 55.2 & 0.1 & 0 & 0.9 & 1000 \\
\hline
\end{tabular}

Isotopic analyses are shown in Table 4-4. Insufficient sample was available for analysis of carbon isotopic ratio in AM3 due to making splits of the sample during changes of analytical labs. Interpretation of the isotopic analyses is done in tandem with cation and anion chemistry and with published groundwater isotopic data for the Animas Valley.

Table 4-4. Isotopic Analyses. See Appendix 4 for explanation of delta ( $\delta$ ).

\begin{tabular}{|c|c|c|c|c|c|c|}
\hline SAMPLE & SITE & $\delta^{2} \mathrm{D}$ & $\delta{ }^{18} \mathbf{O}$ & $\delta{ }^{13} \mathrm{C}$ & $\delta{ }^{34} \mathrm{~S}$ & ${ }^{87} \mathrm{Sr} /{ }^{86} \mathrm{Sr}$ \\
\hline \hline AM1 & Burgett \#1 & -76 & -9.9 & -10.6 & 8.50 & 0.728344 \\
\hline AM2 & Burgett \#C & -76 & -10.0 & -8.6 & 8.55 & 0.725616 \\
\hline AM3 & Burgett \#6 & -77 & -10.8 & n/a & 8.34 & 0.727433 \\
\hline AM4 & AmeriCulture Fed & -70 & -10.1 & -10.0 & 8.84 & 0.728861 \\
\hline
\end{tabular}

\subsection{CATION AND ANION SYSTEMATICS}

\subsection{Piper Diagram}

Piper diagrams (Piper, 1944) provide an initial graphic display of geochemical data from the geothermal wells. A Piper diagram shows major cation and anions in terms of millequivalent percentages on cation and anion trilinear plots. The anion and cation percentages are projected from the respective triangle plots on to a central diamond plot. As whole, the Piper diagram allows immediate recognition of chemical type and some basic 
processes that may be occurring such as mixing, dissolution of evaporate minerals, and cation exchange between water and clay or silicate minerals.

A Piper diagram plot of sampled waters is shown in Figure 4-1. The Lightning Dock geothermal waters are sodium sulfate with total dissolved solids (TDS) ranging from 1,000 to $1,180 \mathrm{mg} / \mathrm{L}$. The Piper diagram shows an apparent mixing trend in the thermal waters with AM1 as end-member geothermal water. The AM4 well appears to have a small fraction of non-thermal water mixed with thermal water.

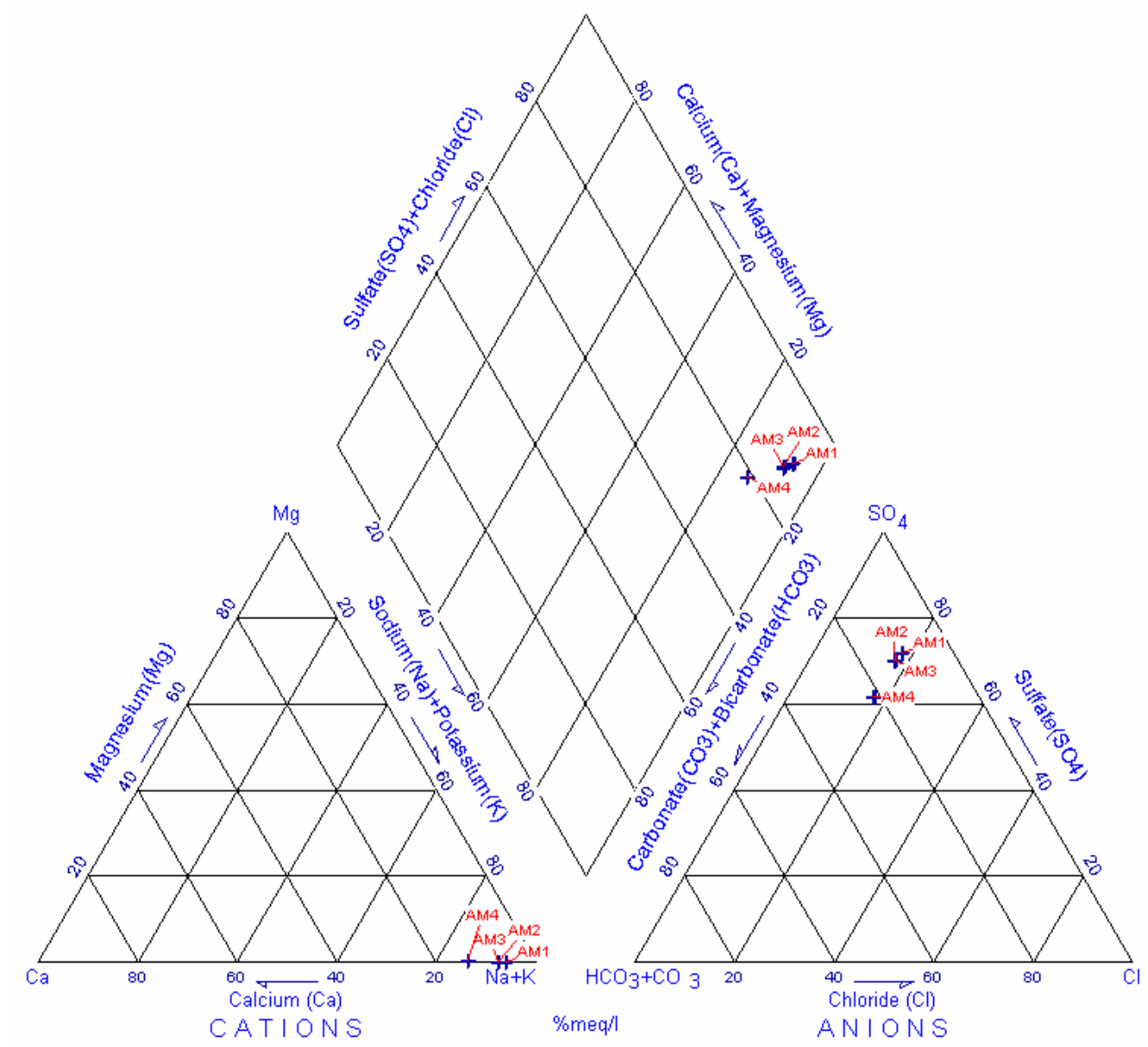

Figure 4-1. Piper Diagram of Samples Lightning Dock wells.

\subsection{Bromide and Chloride/Bromide Ratio}

Typically $\mathrm{Cl}$ acts as the most conservative major ion in groundwater and is not directly involved in most chemical reactions except for the dissolution of soluble minerals that are contained in evaporate rocks such as halite. Therefore, 
where evaporates are absent, Cal variation is largely the result of mixing of young low TDS waters and older thermal waters. Bromide $(\mathrm{Br})$ acts much like Cal in solution; however, $\mathrm{Br}$ is considerably less abundant in natural groundwater. In addition, $\mathrm{Br}$ is very conservative and even more soluble than $\mathrm{Cl}$ (Davis and others, 1998).

The $\mathrm{Cl} / \mathrm{Br}$ ratio is sensitive to mineral and chemical sources or provenance. The $\mathrm{Cl} / \mathrm{Br}$ ratio is very low in most natural systems like seawater (290), meteoric water (50-180), organic materials (20-200), and igneous and metamorphic rocks (100-500) (Davis and others, 1998). Higher $\mathrm{Cl} / \mathrm{Br}$ ratios are generally associated with anthropogenic sources such as road salt, sewage, industrial chemicals or waste, agriculture processes, and with the natural dissolution of evaporate minerals or release of salts in mineral fluid inclusions during water-rock equilibration.

High $\mathrm{Cl} / \mathrm{Br}$ ratios in evaporates are a result of the differential solubility between $\mathrm{Br}$ and $\mathrm{Cl}$. Since $\mathrm{Br}$ is much more soluble than $\mathrm{Cl}$, halite forms as a nearly pure $\mathrm{NaCl}$ crystal with most $\mathrm{Br}$ remaining in the brine. Dissolution and reprecipitation results in even higher $\mathrm{Cl} / \mathrm{Br}$ ratios in the solid precipitate (Davis and others, 1998; Hounslow, 1995; and Hanor, 1988 and 1994).

At Lightning Dock, the highest $\mathrm{Cl} / \mathrm{Br}$ ratios (328 to 376) are found in the hottest geothermal wells and the variation of the $\mathrm{Cl} / \mathrm{Br}$ ratios is relatively low. In the Rio Grande rift, geothermal water generally has highly variable and much higher $\mathrm{Cl} / \mathrm{Br}$ ratios (800 to 1,361) (Witcher and others, 2004). The high $\mathrm{Cl} / \mathrm{Br}$ ratios relate to geochemical processes along deep regional flow paths, in which water typically progresses from $\mathrm{HCO}_{3}$ through $\mathrm{SO}_{4}$ to $\mathrm{Cl}$ in anion character with increasing time, depth and flow path length (Mazor, 1997). Processes may include dissolution of evaporate minerals from Paleozoic marine rocks. The large differences in $\mathrm{Cl} / \mathrm{Br}$ between non-thermal and thermal water can be used to fingerprint flow paths of geothermal waters and to identify mixing with shallow non-thermal groundwater.

Bromide $(\mathrm{Br})$ concentrations show little variation from 0.26 to $0.27 \mathrm{mg} / \mathrm{L}$ in the hottest geothermal waters (AM1, AM2, and AM3). The coolest thermal water 
(AM4) has a higher $\mathrm{Br}$ concentration of $0.37 \mathrm{mg} / \mathrm{L}$. Figure $4-2$ is a plot of $\mathrm{Cl} / \mathrm{Br}$ versus $\mathrm{Cl}$. The apparent vertical trend in the $\mathrm{Cl} / \mathrm{Br}$ ratio with increasing $\mathrm{Cl}$ between AM3 and AM2 may be interpreted as a boiling trend. In other words, $\mathrm{Cl}$ and $\mathrm{Br}$ are both concentrated at the same rate by loss of water by boiling. With mixing the $\mathrm{Cl} / \mathrm{Br}$ ratio would change. Sample AM3 is located up hydraulic

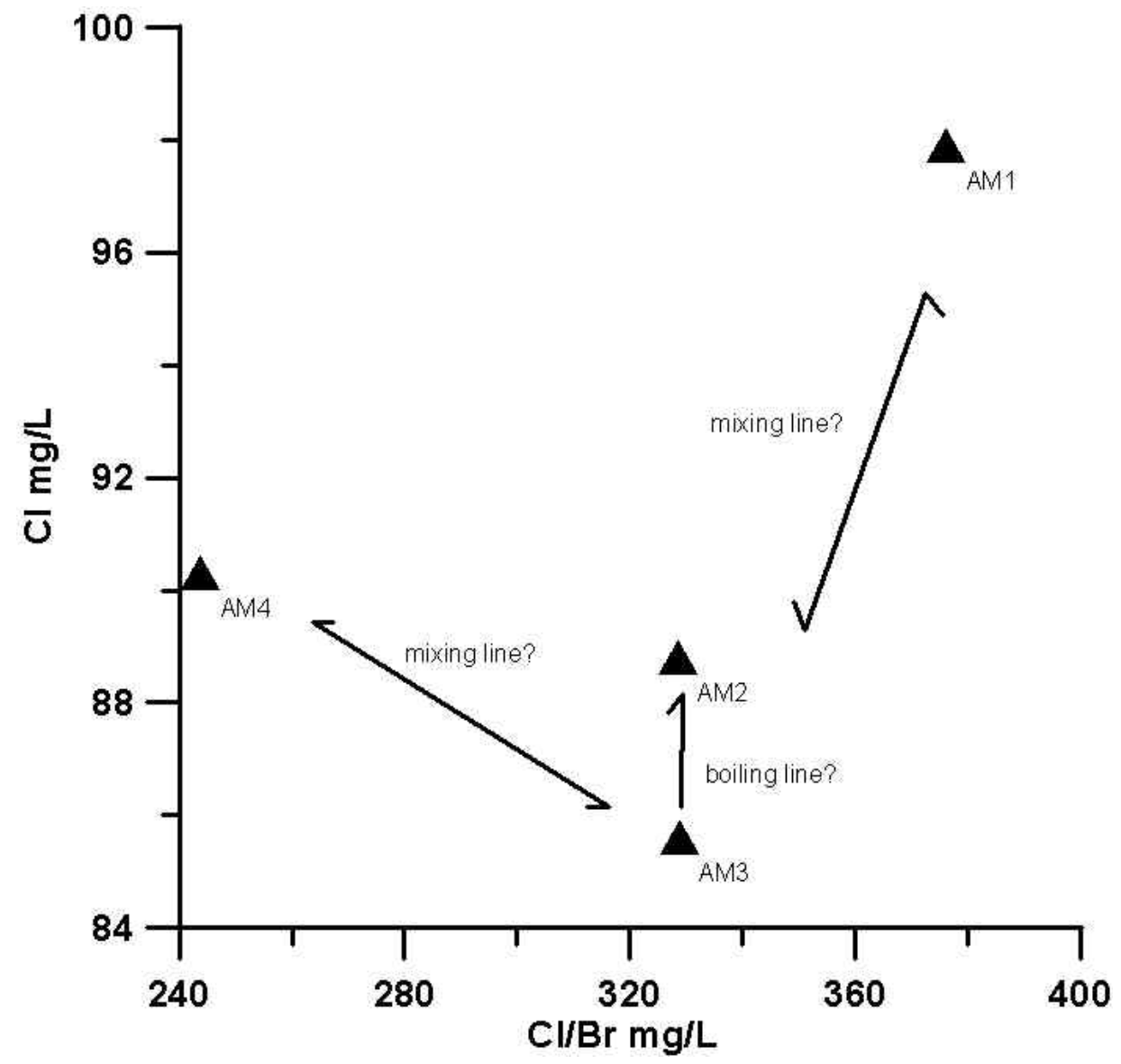

Figure 4-2. $\quad \mathrm{Cl} / \mathrm{Br}$ ratio versus $\mathrm{Cl}$.

gradient from AM2 and AM3 is located over the most intense area of the Lightning Dock heat flow anomaly.

Samples AM3 and AM4 may be mixtures of geothermal water with the composition of AM1 and shallow cold groundwater. If this is true, then two end members of cold groundwater with different chemistry may be involved. The local hydrogeology appears to support this hypothesis. The hot wells AM2 and AM3 are located on the eastern half of the heat flow anomaly on the toe of the alluvial apron or alluvial fan shed from the Pyramid Mountains to the east. Pump 
test results indicate that a hydraulic barrier separates AM4 from AM1, AM2, and AM3 (Witcher, 2001). Gravity data suggests the barrier may represent a major basin-bounding fault zone (Kucks and others, 2001). In other words, AM2 and AM3 have a mixed component of cold water recharged from the coarse-grained alluvial fan deposits and Pyramid Mountains to the southeast and AM4 has a cold-water mix component from the fine-grained basin-fill deposits to the south and southwest.

When the $\mathrm{Cl} / \mathrm{Br}$ ratios are plotted against $\mathrm{SiO}_{2}$, a linear trend from AM4 through AM2 and AM3 to AM1 (Figure 4-3) is observed. The trend may be further evidence for mixing of thermal and non-thermal water and have use in a geothermometer-mixing model to predict deep subsurface temperatures. However, silica is not a conservative chemical species and further analysis is required.

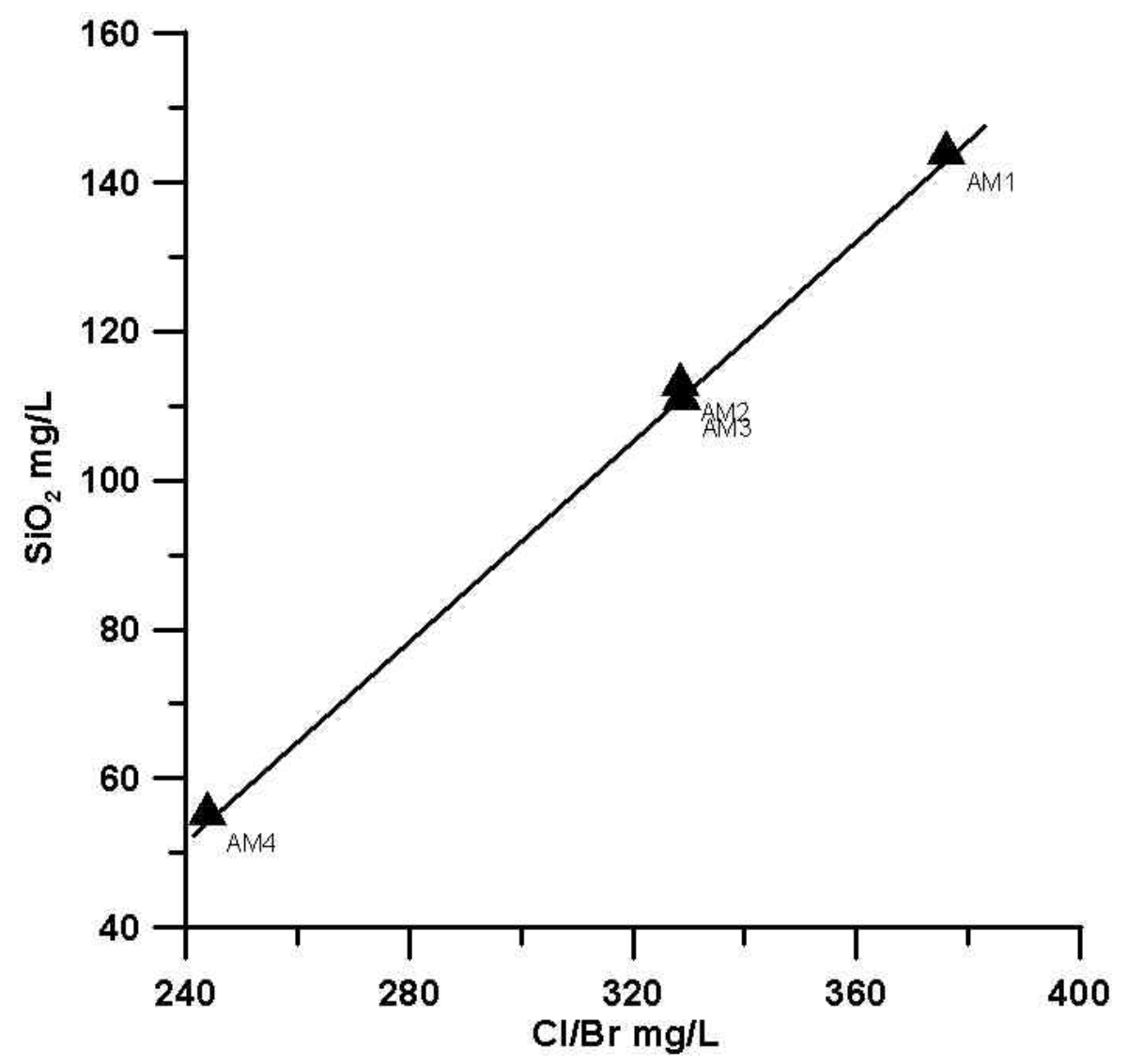

Figure 4-3. $\mathrm{Cl} / \mathrm{Br}$ ratio versus $\mathrm{SiO}_{2}$. 


\subsection{Silica Concentrations}

Silica $\left(\mathrm{SiO}_{2}\right)$ concentrations are temperature dependent and can be used to quantify subsurface temperatures (Fournier, 1960 and 1977). This is because of the slow kinetics of dissolved $\mathrm{SiO}_{2}$ equilibrium with quartz at lower temperatures below $150{ }^{\circ} \mathrm{C}$ (Rimstidt and Barnes, 1980). In other words, high $\mathrm{SiO}_{2}$ concentrations may be retained at low temperatures for long periods of time after the geothermal fluids have cooled below $150^{\circ} \mathrm{C}$.

Dissolution of aluminosilicate minerals such as potassium feldspar (orthoclase or sanidine) can release $\mathrm{K}$ and $\mathrm{SiO}_{2}$ to solution and result in higher alkalinity or bicarbonate $\left(\mathrm{HCO}_{3}\right)$ concentrations. Feldspar-rich rhyolite ash flow tuff and rhyolite is common in the subsurface at Lightning Dock. Figure 4-4 and 4-5 are comparisons of $\mathrm{K}$ and $\mathrm{HCO}_{3}$ concentrations respectively versus dissolved $\mathrm{SiO}_{2}$. A negative trend of higher $\mathrm{SiO}_{2}$ with a correlative lower $\mathrm{HCO}_{3}$ is observed. This suggests that $\mathrm{SiO}_{2}$ concentrations are temperature dependent rather than the result of dissolution of aluminosilicate minerals. The high $\mathrm{K}$ concentrations are a common result of geothermal processes (Fournier and Truesdell, 1973; and Giggenbach, 1988).

Figure 4-6 is a plot of $\log \mathrm{SiO}_{2}$ concentration versus temperature. The temperature dependent equilibrium curves for the solid silica species of quartz, alpha-cristobalite, chalcedony, and amorphous silica are shown. Sampled wells plot near the chalcedony curve with much scatter. This would suggest mixing at temperatures below $150{ }^{\circ} \mathrm{C}$ with no equilibration of the $\mathrm{SiO}_{2}$ concentrations in the waters with respect to chalcedony (or quartz). 


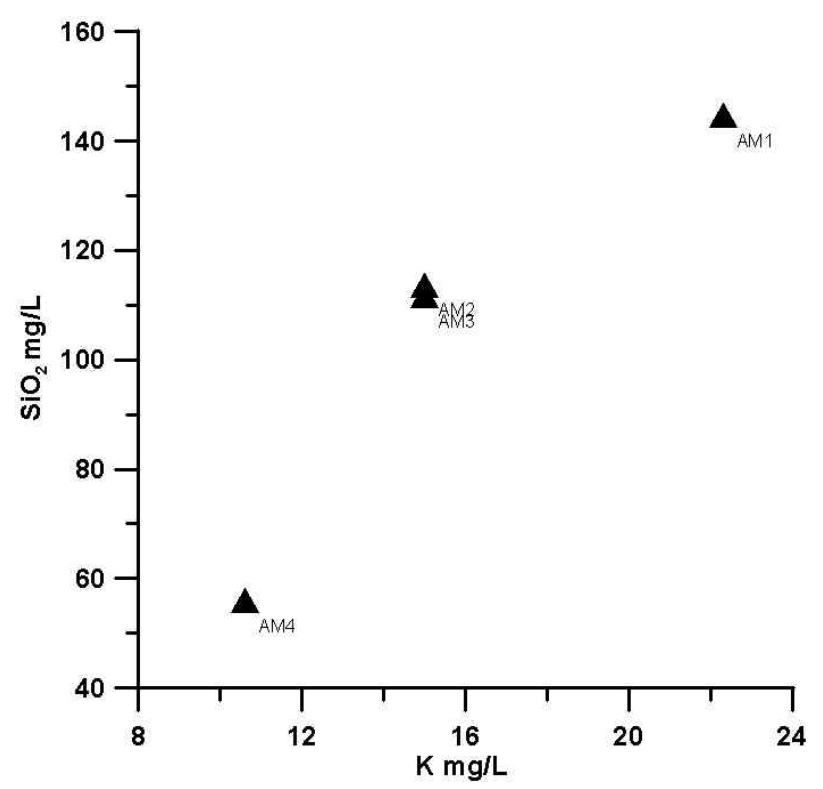

Figure 4-4. $\mathrm{K}$ versus $\mathrm{SiO}_{2}$.

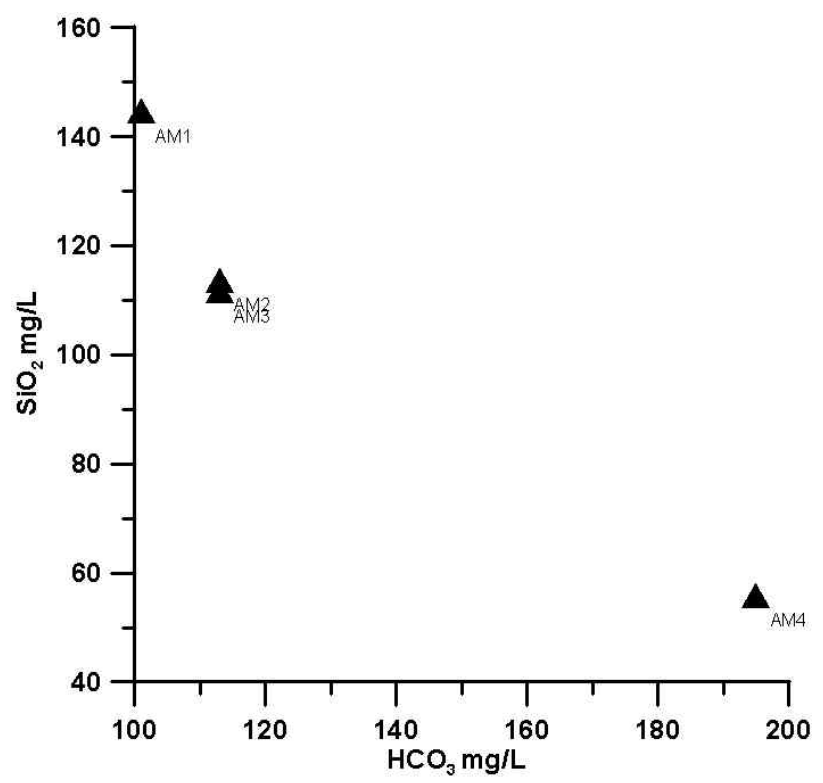

Figure 4-5. $\mathrm{HCO}_{3}$ versus $\mathrm{SiO}_{2}$. 


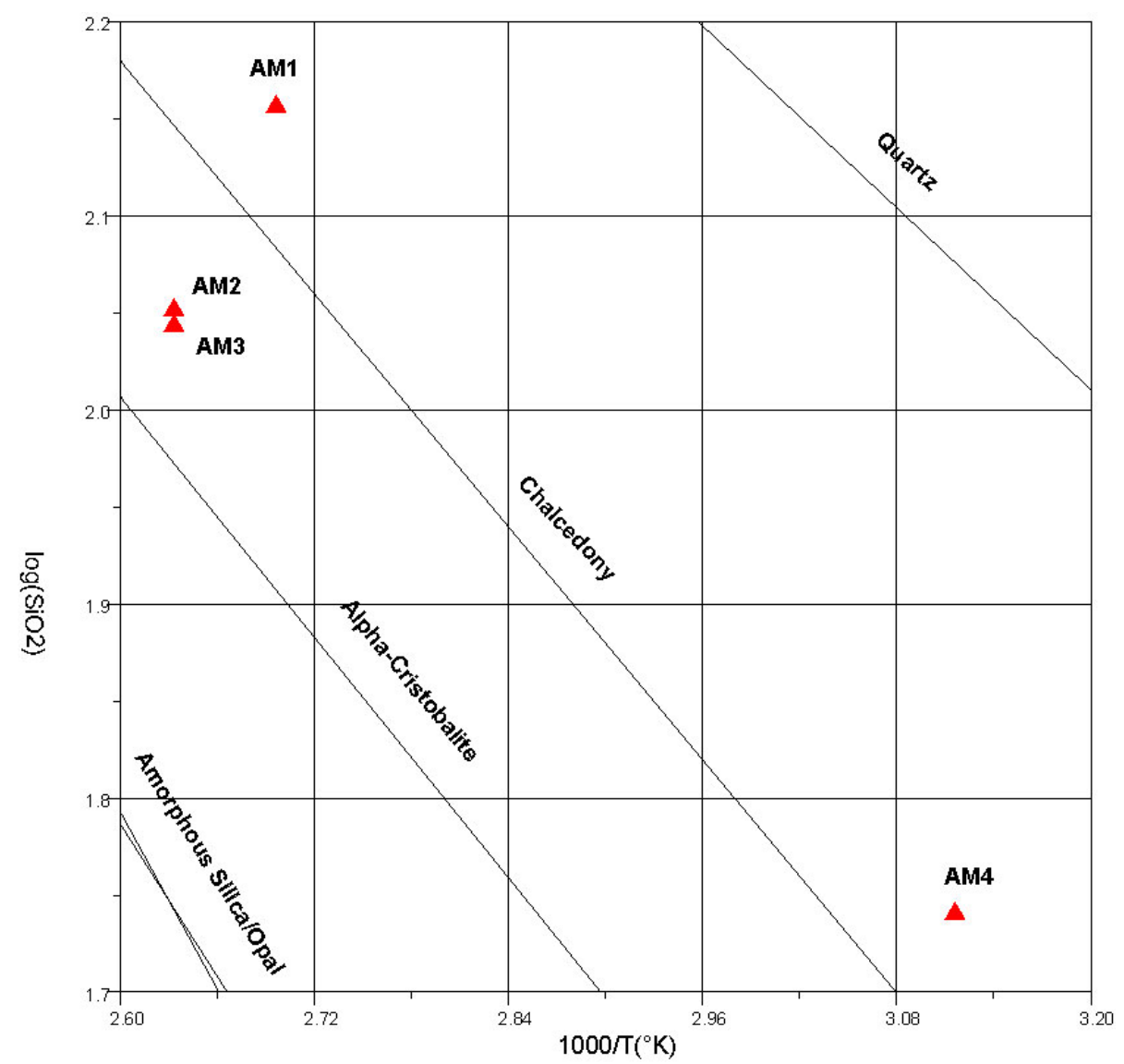

Figure 4-6. Temperature $\left(1000 / \mathrm{T}\left({ }^{\circ} \mathrm{K}\right)\right.$ versus log $\mathrm{SiO}_{2}$ showing temperaturedependent equilibrium curves of solid silica phases.

\section{$4.7 \quad$ ISOTOPE SYSTEMATICS}

\subsubsection{Introduction}

Isotope systems analysis helps to identify sources and processes associated with water chemistry and salinity. For ease of discussion, delta $(\delta)$ notation is used with the stable isotopes. Delta $(\delta)$ is the per thousand (per mil) comparison of the ratio of heavy to light isotopes in a sample compared to a standard. Appendix 4 details the nomenclature used for reporting isotope analyses. 


\subsubsection{Hydrogen and Oxygen ( $\delta \mathrm{D}$ and $\left.\delta^{18} \mathrm{O}\right)$}

The stable isotopes of hydrogen $\left({ }^{1} \mathrm{H}\right)$ and deuterium $\left({ }^{2} \mathrm{H}\right)$, and oxygen $\left({ }^{16} \mathrm{O}\right.$ and $\left.{ }^{18} \mathrm{O}\right)$ are the most common isotopes in water $\left(\mathrm{H}_{2} \mathrm{O}\right)$. In water, the light isotopes of hydrogen $\left({ }^{1} \mathrm{H}\right)$ and oxygen $\left({ }^{16} \mathrm{O}\right)$ comprise more than $99 \%$ of a water molecule, while the heavier isotopes comprise less than $1 \%$. Because atomic mass is almost entirely protons and neutrons, addition of a neutron in a hydrogen $\left({ }^{1} \mathrm{H}\right)$ nucleus to form deuterium $\left({ }^{2} \mathrm{H}\right.$ or $\left.\mathrm{D}\right)$ practically doubles the mass. Addition of two neutrons to form ${ }^{18} \mathrm{O}$ increases the oxygen atomic mass by approximately $12.5 \%$. Isotopic mass differences are significant enough to cause different chemical and physical reaction rates and allow measurable fractionation or separation of heavy and light water. For instance, the hydrologic cycle fractionates light and heavy water during evaporation and condensation. Lighter water evaporates more easily and heavy water condenses more readily (Faure 1986; Clark and Fritz, 1997; Gat, 1996; and Mazor, 1997). Enrichment of the heavy isotope with respect to the standard is indicated by increased values of $\delta \mathrm{D}$ and $\delta^{18} \mathrm{O}$, and depletion of the heavy isotope is noted by decreased values.

Relative enrichment and depletion of isotope ratios in water can be characterized by plotting $\delta D$ versus $\delta^{18} \mathrm{O}$ (Figure 4-7). Data is from this study and Elston and others (1983). Based on a large number water stable isotope analyses of precipitation from around the world, Craig (1961) found a systematic worldwide variation that described a sloping line or Global Meteoric Water Line (GMWL). The GMWL is quantified by the equation: $\delta D=8 \delta^{18} O+10$. The intercept (10) is referred to as deuterium excess. Dansgaard (1964) found that temperature was a major determining factor in precipitation (meteoric water) isotope depletion. Other important factors include: 1) altitude, 2) storm duration, 3) a continental effect, 4) a seasonal effect, and 5) a paleoclimate effect (Fontes 1980). Higher altitudes and continental interiors receive isotopically lighter precipitation. In general, winter precipitation is isotopically lighter than in summer and longer storm events result in relatively lighter isotopic precipitation. Cooler paleoclimatic conditions also result in isotopically lighter meteoric water. 


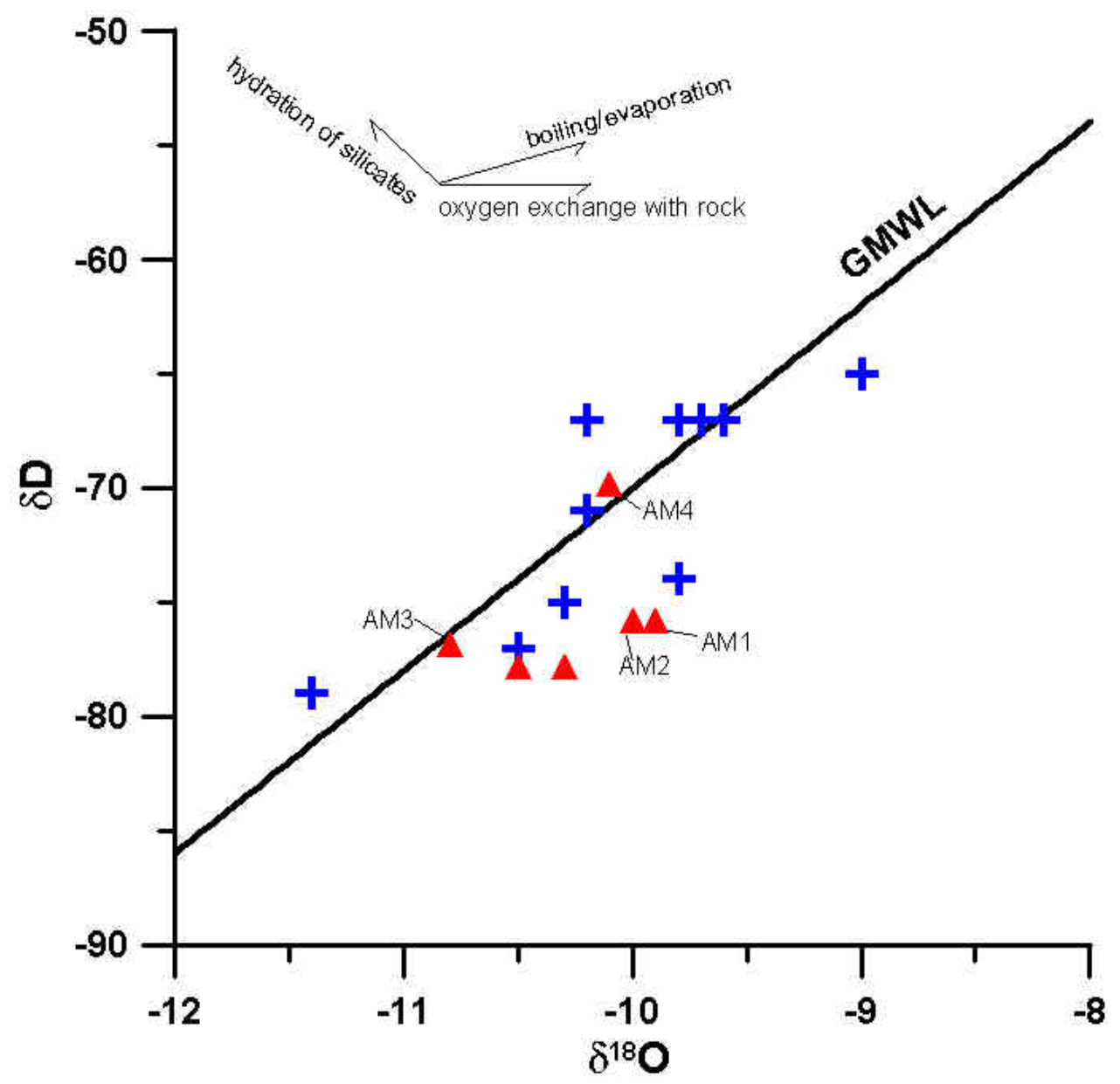

Figure 4-7. $\delta^{18} \mathrm{O}$ versus $\delta \mathrm{D}$ with diagram showing general trends for various geochemical physical processes. GMWL is the Global Mean Water Line (Craig, 1961).

Two processes can cause isotope values to plot to the right of the meteoric water line or GMWL. With evaporation or boiling, residual waters attain heavier isotopic composition due to preferential evaporation of lighter molecules. Normally, residual waters plot as an "evaporation line" with a slope between two and five (Clark and Fritz 1997). Second, "old" groundwater and geothermal waters will gain heavy oxygen $\left({ }^{18} \mathrm{O}\right)$ from rocks by exchange processes associated with water-rock interaction and hydrothermal alteration. These waters typically plot horizontally to the right of the meteoric source water because rocks contain very little hydrogen for exchange and the $\delta D$ value remains constant. The amount of oxygen exchange or change in $\delta^{18} \mathrm{O}$ is a function of rock 
composition, texture, temperature and length of contact (Fontes, 1980; Nicholson, 1993; Gat, 1996; and Mazor,1997).

Because of arid climate in the region, surface water and shallow groundwater is subject to evaporation processes. With time and distance along the flow path, some shallow groundwater, especially in playa areas, becomes progressively heavier in $\delta \mathrm{D}$ and $\delta^{18} \mathrm{O}$ with a trend that is upward and to the right because of evaporation. Without evaporative fractionation, most non-thermal water in the Animas Valley is heavier than the geothermal waters. In order to obtain the lighter $\delta \mathrm{D}$ and $\delta^{18} \mathrm{O}$ observed in Lightning Dock geothermal waters, precipitation and recharge must have occurred during a much cooler climate. The Lightning Dock geothermal waters show a $\delta^{18} \mathrm{O}$ shift to the right from hydrothermal alteration processes and appear to show an upward to the right shift in $\delta \mathrm{D}$ and $\delta^{18} \mathrm{O}$ from minor subsurface boiling.

Sample AM4 and AM3 plot along the GMWL. AM4 probably represents a mixture of geothermal water and cold water. Alternatively, AM4 may represent cold groundwater that is conductively heated from below. A plot of $\delta \mathrm{D}$ versus $\mathrm{Cl} / \mathrm{Br}$ ratio provides additional evidence that minor subsurface boiling is occurring (Figure 4-8).

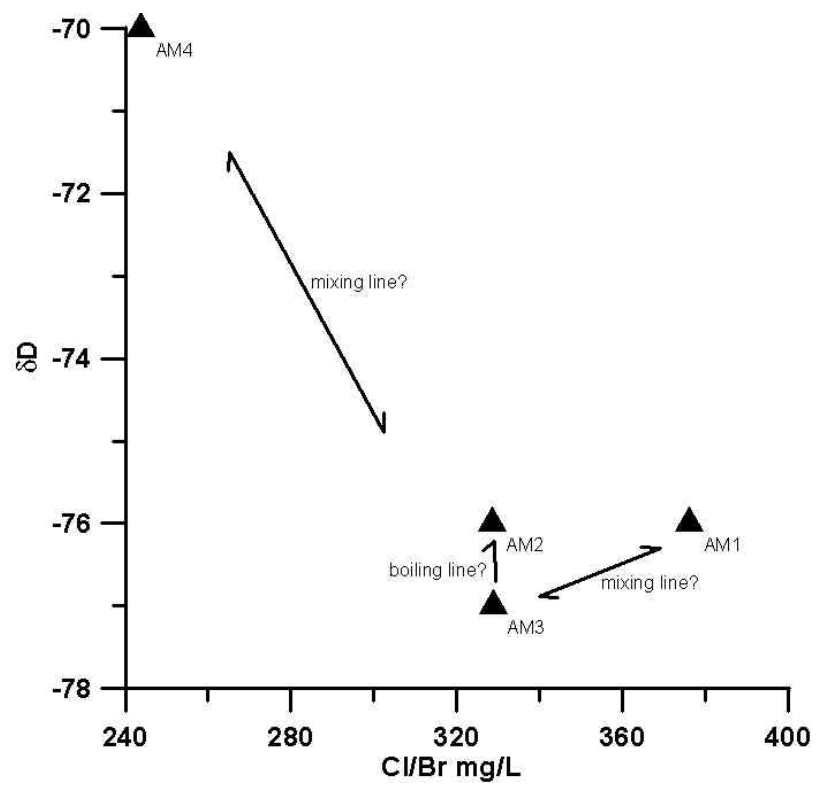

Figure 4-8. $\mathrm{Cl} / \mathrm{Br}$ ratio versus $\delta \mathrm{D}$. 
Samples AM3 (up gradient) and AM2 (down gradient) show a shift to heavier $\delta \mathrm{D}$ with no change in the $\mathrm{Cl} / \mathrm{Br}$ ratio that is consistent with fractionation of $\delta \mathrm{D}$ by boiling. Residual fluids (AM2) show increased $\mathrm{Cl}$ and $\mathrm{Br}$, but the $\mathrm{Cl} / \mathrm{Br}$ ratio remains the same.

\subsubsection{Strontium $\left({ }^{87} \mathrm{Sr} /{ }^{86} \mathrm{Sr}\right)$ Ratio}

Strontium ( $\mathrm{Sr}$ ) frequently replaces $\mathrm{Ca}$ in mineral structures because of similar ionic radius. Strontium has four stable isotopes, ${ }^{84} \mathrm{Sr},{ }^{86} \mathrm{Sr},{ }^{87} \mathrm{Sr}$, and ${ }^{88} \mathrm{Sr}$. With time the natural reservoir of ${ }^{87} \mathrm{Sr}$ is slowly increasing due to beta decay of ${ }^{87} \mathrm{Rb}$ (rubidium), with a half-life of $48.8 \times 10^{9}$ years to form ${ }^{87} \mathrm{Sr}$. Isotopes of $\mathrm{Sr}$ are reported as mass ratios such as ${ }^{87} \mathrm{Sr} /{ }^{86} \mathrm{Sr}$ (Faure 1986, Capo and others, 1998, and Stewart and others, 1998).

Because of very small mass differences between the isotopes of $\mathrm{Sr}$, the ${ }^{87} \mathrm{Sr} /{ }^{86} \mathrm{Sr}$ ratio is not changed by fractionation during chemical or physical processes as observed with lighter isotopic systems such as $\mathrm{H}$ and $\mathrm{O}$. $\mathrm{An} \mathrm{Sr}$ ratio $\left({ }^{87} \mathrm{Sr} /{ }^{86} \mathrm{Sr}\right.$ initial) is set at the time of mineral formation. Because $\mathrm{Rb}$ has an ionic radius similar to $\mathrm{K}$, K-rich rocks may be enriched in ${ }^{87} \mathrm{Rb}$. With sufficient time, a rock with high $\mathrm{K}$ content may have high ${ }^{87} \mathrm{Sr}$ as a result of ${ }^{87} \mathrm{Rb}$ beta decay.

The ${ }^{87} \mathrm{Sr} /{ }^{86} \mathrm{Sr}$ ratio of the Lightning Dock geothermal wells reflects the flow paths and rock and mineral sources in the region. These sources may include Precambrian granite and metamorphic rocks, Paleozoic carbonate rocks, Tertiary and Quaternary mafic and intermediate composition volcanic rocks and intrusions, Tertiary silicic volcanic and plutonic rocks, and Quaternary eolian dust. Flow paths through Tertiary and Quaternary Animas Valley sediments can reflect a mixture of all sources as these sedimentary units have varied mineral and rock provenance. Older $(>1.5 \mathrm{Ba})$ Precambrian granites have initial ${ }^{87} \mathrm{Sr} /{ }^{86} \mathrm{Sr}$ ratios between 0.700 and 0.708 while the younger (<1.5 b.y.) Precambrian K-rich granites in the region have initial ${ }^{87} \mathrm{Sr} /{ }^{86} \mathrm{Sr}$ ratios between 0.705 and 0.728 (Condie and Budding, 1979). Today, measured Precambrian ${ }^{87} \mathrm{Sr} /{ }^{86} \mathrm{Sr}$ ratios may range up to 0.81 (Butcher, 1990). Important variations in the initial ${ }^{87} \mathrm{Sr} /{ }^{86} \mathrm{Sr}$ 
ratio occur in marine carbonate rocks during the Phanerozoic (Burke and others, 1982; McArthur and others, 2001; and Veizer and others, 1999). The ratio changes reflect large-scale plate tectonic related variance in weathering rates and terrestrial sources for initial ${ }^{87} \mathrm{Sr} /{ }^{86} \mathrm{Sr}$ ratios in Paleozoic seas. During the Pennsylvanian, the average Sr ratio was generally between 0.7080 and 0.7085 . Because of low $\mathrm{K}$ content and high Ca content, the ${ }^{87} \mathrm{Sr} /{ }^{86} \mathrm{Sr}$ ratios of today's Pennsylvanian rocks (such as the Horquilla Formation at Lightning Dock) probably remains below 0.710 . Tertiary and Quaternary basalts have initial ${ }^{87} \mathrm{Sr} /{ }^{86} \mathrm{Sr}$ ratios of 0.703 to 0.704 (Elston, 1976). Mid-Tertiary basaltic andesites have initial ${ }^{87} \mathrm{Sr} /{ }^{86} \mathrm{Sr}$ between 0.707 and 0.708 (Elston, 1976). Because of low K content and relatively high $\mathrm{Ca}$ content compared to $\mathrm{K}$ and likely low $\mathrm{Rb}$ content, the basalt and basaltic andesite initial ${ }^{87} \mathrm{Sr} /{ }^{86} \mathrm{Sr}$ ratios are valid today. On the other hand, Tertiary silicic volcanics and plutons have initial ${ }^{87} \mathrm{Sr} /{ }^{86} \mathrm{Sr}$ ratios ranging from 0.71 to 0.73 (Elston, 1976). Because these rocks may have high $\mathrm{Rb}$ contents as a consequence of high $\mathrm{K}$, measured ${ }^{87} \mathrm{Sr} /{ }^{86} \mathrm{Sr}$ ratios of today are higher. Butcher (1990) reports present day ${ }^{87} \mathrm{Sr} /{ }^{86} \mathrm{Sr}$ values up to 0.7488 for midTertiary silicic rocks in the Organ Mountains. The Organ Mountain rhyolites are close in age to the silicic volcanics of the Pyramid Mountains. Caliche provides a proxy for the Quaternary eolian dust ${ }^{87} \mathrm{Sr} /{ }^{86} \mathrm{Sr}$ ratio source reservoir. Caliche ${ }^{87} \mathrm{Sr} /{ }^{86} \mathrm{Sr}$ ratios range from 0.708 to 0.716 (Van der Hoven, 1994; and Capo and others, 1998). However, the contribution of $\mathrm{Sr}$ dissolved from eolian dust is probably minor when accounting for the ${ }^{87} \mathrm{Sr} /{ }^{86} \mathrm{Sr}$ ratio of groundwater of the Animas Valley.

Figure 4-9 shows the $\mathrm{Cl} / \mathrm{Br}$ ratio versus the ${ }^{87} \mathrm{Sr} /{ }^{86} \mathrm{Sr}$ ratio for the Lightning Dock geothermal wells. The ${ }^{87} \mathrm{Sr} /{ }^{86} \mathrm{Sr}$ ratios are very close and only range between 0.7274 and 0.7288 . 


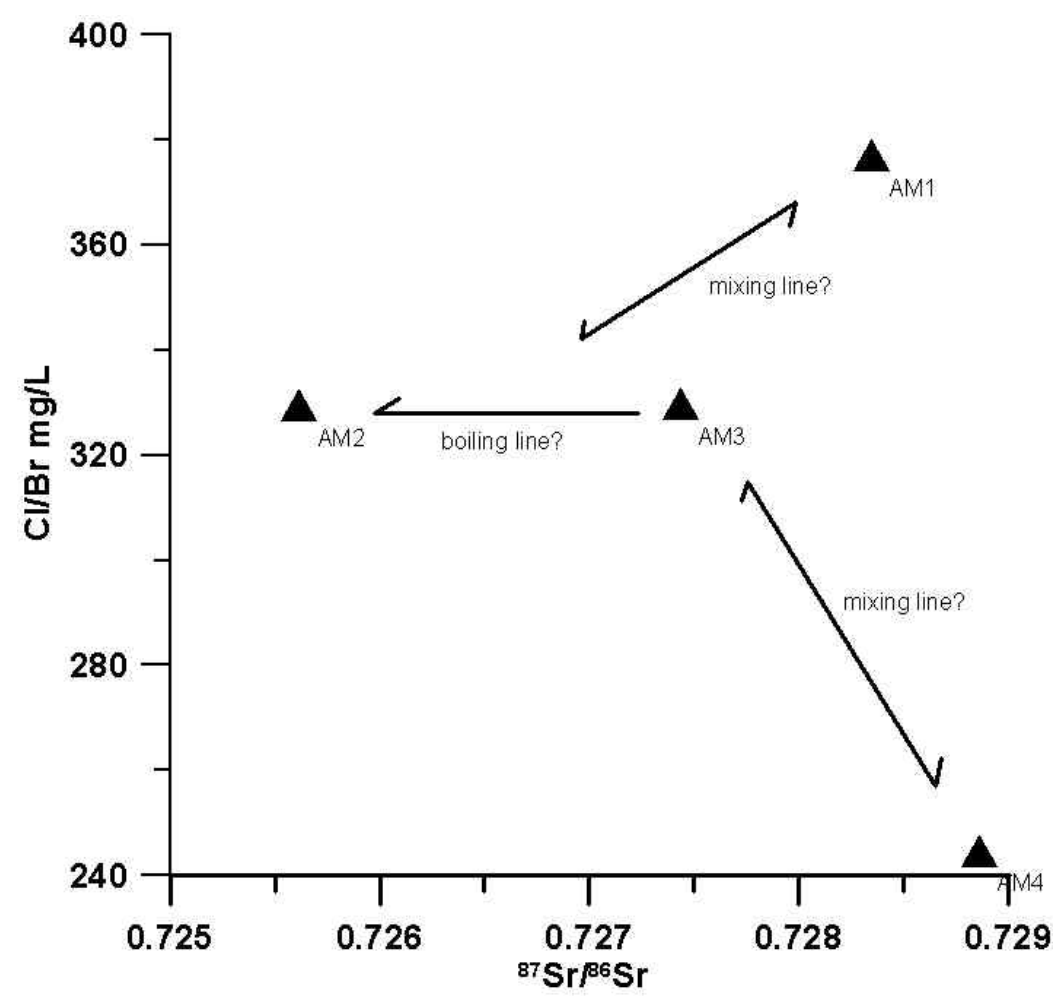

Figure 4-9. ${ }^{87} \mathrm{Sr} /{ }^{86} \mathrm{Sr}$ versus $\mathrm{Cl} / \mathrm{Br}$.

Geothermal groundwater at Lightning Dock has probably flowed through Precambrian granite and/or possibly mid-Tertiary silicic volcanics and granite plutons in order to acquire ${ }^{87} \mathrm{Sr} /{ }^{86} \mathrm{Sr}$ ratios greater than 0.725 . Long-term flow through aquifers with a provenance that is dominated by Paleozoic carbonate and mid-Tertiary mafic to intermediate volcanic rocks will have ratios below 0.710 .

\subsubsection{Carbon $\left(\delta^{13} \mathrm{C}\right)$}

Carbon (C) has three common isotopes; ${ }^{12} \mathrm{C}$ and ${ }^{13} \mathrm{C}$ are stable, while the ${ }^{14} \mathrm{C}$ isotope is radioactive. In this study, only the stable isotopes are discussed. The abundance of $\mathrm{C}$ stable isotopes is ${ }^{12} \mathrm{C}(98.89 \%)$ and ${ }^{13} \mathrm{C}(1.11 \%)$. Carbon isotopes are fractionated by a variety of natural processes, including plant photosynthesis and isotope exchange reactions between carbonate minerals.

Plant photosynthesis can be important and result in ${ }^{12} \mathrm{C}$ enrichment of organic carbon inclusions in sediments, petroleum and coal (Faure 1986). Hoefs (1997) describes two separate pathways for sediment diagenesis, a shallow meteoric pathway and a burial pathway for deep-sea environments. The burial 
pathway creates carbonates enriched in ${ }^{13} \mathrm{C}$ from methane production even when ${ }^{12} \mathrm{C}$ enriched organic carbon is present in the original sediment. The resulting carbonates can have high $\delta^{13} \mathrm{C}$ values (Faure 1986 and Hoefs 1997).

At Lightning Dock, thermal waters have $\delta^{13} \mathrm{C}$ values of $(-8.6$ to -10.6$)$. The $\delta^{13} \mathrm{C}$ values in the thermal water are probably too light for water-rock equilibration along a deep regional flow path through marine carbonates of Cambrian to Pennsylvanian age. Marine carbonate rocks typically have $\delta^{13} \mathrm{C}$ values from -4 to 6 (Clark and Fritz, 1997; and Veizer and others, 1999). Early Mississippian (Alamogordo Member of the Lake Valley Formation) in south central New Mexico has average $\delta^{13} \mathrm{C}$ at 2.7 (Stanton and others, 2002). Algeo (1996) presents carbon isotopic data on the Middle Pennsylvanian Gobbler Formation in the Sacramento and San Andres Mountains of south central New Mexico. While $\delta^{13} \mathrm{C}$ ranges from 5 to -5 , most $\delta^{13} \mathrm{C}$ values for the Gobbler Formation are 2 to 4 .

Waters with significant atmosphere-derived fractions of dissolved carbonate species will have $\delta^{13} \mathrm{C}$ values lower than -4 but probably greater than -15 . Average atmospheric $\delta^{13} \mathrm{C}$ is about -7 . Calcite and carbonate in the upper basin fill deposits of south central New Mexico have $\delta^{13} \mathrm{C}$ between -2.2 and -5.5 (Mack and others, 1994; and Mack and others, 2000); while surface carbonate soils (caliche) $\delta^{13} \mathrm{C}$ range between -0.6 and -11 (Monger and others, 1998). Monger and others (1998) report organic carbon $\delta^{13} \mathrm{C}$ between -15.7 and -25 in near surface soils.

Like the ${ }^{87} \mathrm{Sr} /{ }^{86} \mathrm{Sr}$ ratios, the $\delta^{13} \mathrm{C}$ values suggest that the Lightning Dock waters have not had a flow path through Paleozoic carbonate rocks and have retained a meteoric water $\delta^{13} \mathrm{C}$ that is consistent with flow through silicic volcanic rocks and granite.

\subsubsection{Sulfur $\delta^{34} \mathrm{~S}$}

The main sources of sulfur for Animas Valley groundwater are probably dissolution of gypsum and weathering of sulfide minerals such as pyrite. Gypsum 
and anhydrite $\left(\mathrm{CaSO}_{4}\right)$ are associated with several Pennsylvanian and Permian rock units and with Tertiary-Quaternary playa deposits. Pyrite occurs as an accessory mineral in many rock units in the subsurface of the area, especially the mid-Tertiary silicic rocks. Dissolution and weathering releases sulfur into groundwater as a sulfate $\left(\mathrm{SO}_{4}\right)$ anion. Where acid geothermal conditions or subsurface boiling occurs and biogenic reducing processes are active, some sulfur may occur as dissolved hydrogen sulfide $\left(\mathrm{H}_{2} \mathrm{~S}\right)$. However, no significant amount $\mathrm{H}_{2} \mathrm{~S}$ has been measured at Lightning Dock (Norman and Bernhardt, 1982).

Stable sulfur isotopic ratios $\left(\delta^{34} S\right)$ can reflect source and geochemical processes such as biogenic reduction of sulfur. Marine evaporates of Permian age in west Texas typically have $\delta^{34} S$ of 9.6 to 12.5 (Thode and Monster, 1965; and Hill, 1996). Late Permian brines in southeast New Mexico have $\delta^{34} S$ of 7.4 to 9.8 (Hill, 1996). Where sulfur of biogenic heritage occurs, $\delta^{34} S$ can range downward to -30 .

The Lightning Dock geothermal waters show a tight distribution of $\delta^{34} S$ values between 8.50 and 8.84 . The thermal waters may have a component of late Paleozoic dissolved sulfate, although slightly lower than the $\delta^{34} S$ of Permian brines and gypsum in southeast New Mexico. The tight distribution of values suggests that most sulfate is derived from a single source. Sulfate derived from oxidation of disseminated pyrite in mid-Tertiary silicic rocks is the most likely source of sulfur.

\subsection{GEOTHERMOMETRY}

Table 4-5 shows the results of geothermometry calculations for the Lightning Dock samples. Table $4-6$ is a list of the geothermometers with literature references. The general use and assumptions that are inherent in chemical geothermometer interpretations are discussed by Fournier and others (1974). Inspection of Table 4-5 shows that the alpha-cristobalite, betacristobalite and amorphous silica geothermometers are not useful to predict subsurface temperature at Lightning Dock because the predicted temperatures 
are less than measured values. Since the waters show close equilibration to chalcedony (Figure 4-6), chalcedony predicts the maximum shallow reservoir temperatures.

Table 4-5. Geothermometer calculations $\left({ }^{\circ} \mathrm{C}\right)$ for geothermal wells. Underlined and italic values are less than measured well temperatures and are not valid indicators of subsurface temperature.

\begin{tabular}{|c|c|c|c|c|c|c|c|c|}
\hline SAMPLE & TEMP & QRTZ & QRTZ(STM) & A-CRIST & B-CRIST & CHAL & AMORPH & Na/K/Ca \\
\hline \hline AM1 & 97.8 & 159 & 151 & 108 & $\underline{\mathbf{5 9}}$ & 134 & $\underline{\mathbf{3 2}}$ & 166 \\
\hline AM2 & 106.7 & 144 & 138 & 93 & $\underline{\mathbf{4 5}}$ & 118 & $\underline{\mathbf{1 9}}$ & 151 \\
\hline AM3 & 106.7 & 143 & 138 & 92 & $\underline{\mathbf{4 4}}$ & 117 & $\underline{\mathbf{1 8}}$ & 152 \\
\hline AM4 & 47.8 & 106 & 107 & 56 & $\underline{\mathbf{9}}$ & 77 & $\underline{\mathbf{n} / \boldsymbol{a}}$ & 132 \\
\hline
\end{tabular}

\begin{tabular}{|c|c|c|c|c|c|c|c|c|}
\hline SAMPLE & $\mathbf{N a} / \mathrm{K} / \mathrm{Ca}(\mathbf{M g})$ & $\mathbf{N a} / \mathbf{K}(\mathbf{1})$ & $\mathbf{N a} / \mathbf{K}(\mathbf{2})$ & $\mathbf{N a} / \mathrm{Li}(>)$ & $\mathbf{N a} / \mathbf{L i}(<)$ & $\mathbf{N a} / \mathbf{L i}$ & $\mathbf{M g} / \mathbf{L i}$ & $\mathrm{K} / \mathbf{M g}$ \\
\hline \hline AM1 & 159 & 168 & 347 & 95 & 93 & 198 & 173 & 149 \\
\hline AM2 & 144 & 151 & 314 & $\underline{\mathbf{7 4}}$ & $\underline{\mathbf{6 8}}$ & 173 & 147 & 135 \\
\hline AM3 & 149 & 153 & 318 & $\underline{\mathbf{8 0}}$ & $\underline{\mathbf{7 5}}$ & 180 & 147 & 132 \\
\hline AM4 & $\mathbf{n} / \mathbf{a}$ & 131 & 277 & 103 & 102 & 208 & 134 & 98 \\
\hline
\end{tabular}

Table 4-6. Geothermometer references.

\begin{tabular}{|c|c|c|c|}
\hline TYPE & LABEL & NAME & REFERENCE \\
\hline \multicolumn{4}{|l|}{ SILICA } \\
\hline & QRTZ & quartz & \multirow{6}{*}{$\begin{array}{l}\text { Fournier (1977) } \\
\text { Fournier (1977) }\end{array}$} \\
\hline & QRTZ(STEAM) & quartz (maximum steam loss) & \\
\hline & A-CRISTO & alpha-cristobalite & \\
\hline & B-CRISTO & beta-cristobalite & \\
\hline & CHAL & chalcedony & \\
\hline & AMORPH & Amorphous silica & \\
\hline \multicolumn{4}{|l|}{ CATION } \\
\hline & $\mathrm{Na} / \mathrm{K} / \mathrm{Ca}$ & $\mathrm{Na} / \mathrm{K} / \mathrm{Ca}$ & \multirow{9}{*}{$\begin{array}{l}\text { Fournier and Potter (1979) } \\
\text { Fournier and Potter (1979) } \\
\text { Fournier (1979) } \\
\text { Fournier and Truesdell (1973) } \\
\text { Fouillac and Michard (1981) } \\
\text { Fouillac and Michard (1981) } \\
\text { Kharaka and others (1982) } \\
\text { Kharaka and Mariner (1989) } \\
\text { Giggenbach (1988) }\end{array}$} \\
\hline & $\mathrm{Na} / \mathrm{K} / \mathrm{Ca}(\mathrm{Mg})$ & $\mathrm{Na} / \mathrm{K} / \mathrm{Ca}$ (Mg correction) & \\
\hline & $\mathrm{Na} / \mathrm{K}(1)$ & $\mathrm{Na} / \mathrm{K}$ & \\
\hline & $\mathrm{Na} / \mathrm{K}(2)$ & $\mathrm{Na} / \mathrm{K}$ & \\
\hline & $\mathrm{Na} / \mathrm{Li}(>)$ & $\mathrm{Na} / \mathrm{Li}(>10,000 \mathrm{mg} / \mathrm{L})$ & \\
\hline & $\mathrm{Na} / \mathrm{Li}(<)$ & $\mathrm{Na} / \mathrm{Li}(<7,000 \mathrm{mg} / \mathrm{L})$ & \\
\hline & $\mathrm{Na} / \mathrm{Li}$ & $\mathrm{Na} / \mathrm{Li}$ & \\
\hline & $\mathrm{Mg} / \mathrm{Li}$ & $\mathrm{Mg} / \mathrm{Li}$ & \\
\hline & $\mathrm{K} / \mathrm{Mg}$ & $\mathrm{K} / \mathrm{Mg}$ & \\
\hline
\end{tabular}


Quartz and $\mathrm{Na} / \mathrm{K} / \mathrm{Ca}-\mathrm{Mg}$ (correction) geothermometers agree very closely in AM1, AM2, and AM3. Because of possible equilibration of dissolved silica with respect to chalcedony and the fact that the waters show overall partial cation equilibration (Figure 4-10), the quartz and $\mathrm{Na} / \mathrm{K} / \mathrm{Ca}-\mathrm{Mg}$ (correction) probably represent the minimum "deep" reservoir temperature (143 to $\left.159{ }^{\circ} \mathrm{C}\right)$. The temperature predicted by the $\mathrm{Na} / \mathrm{K}$ of Fournier and Truesdell (1973) is not

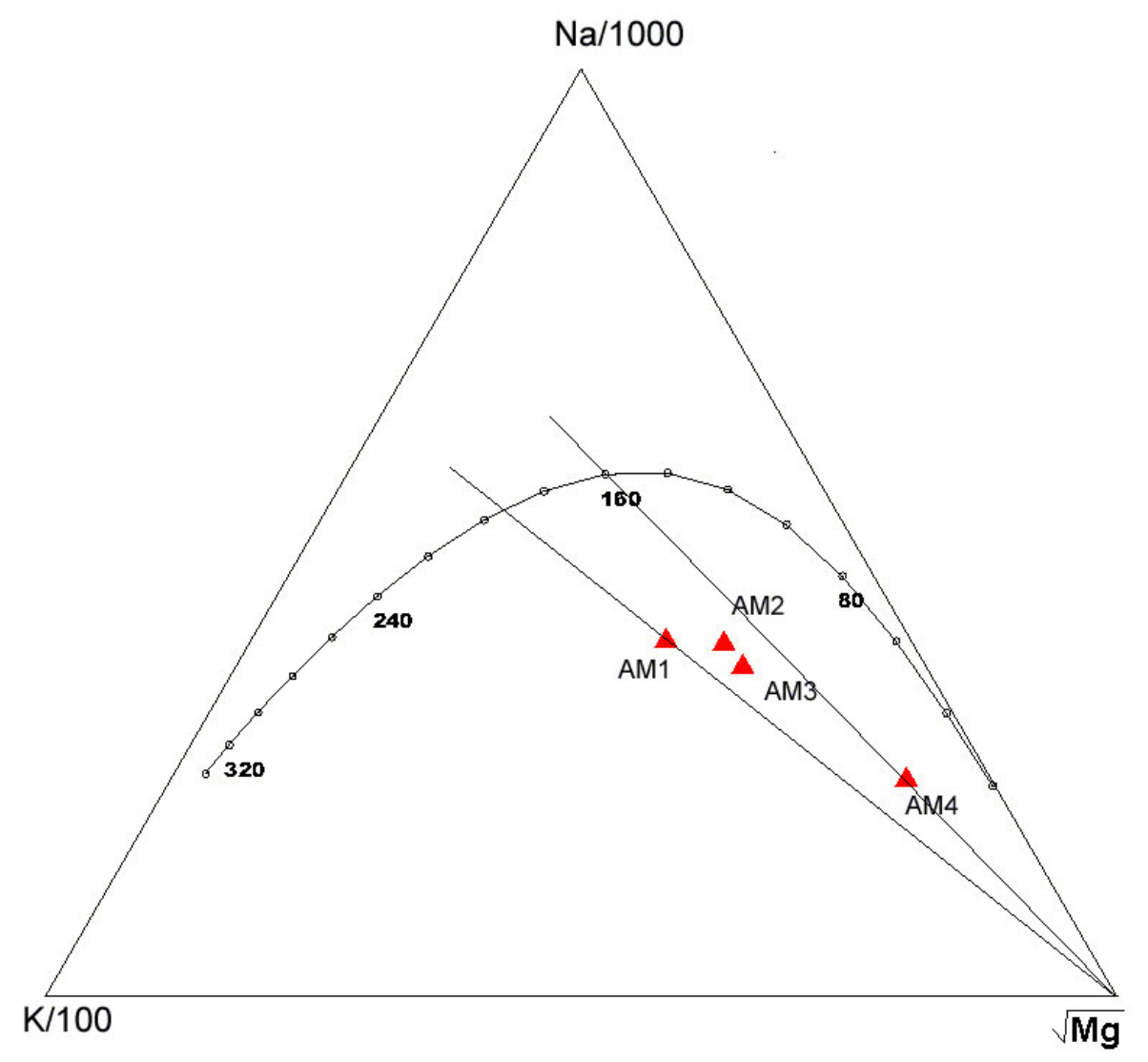

Figure 4-10. Giggenbach Ternary Diagram showing relative equilibrium maturity of geothermal well water and geothermometer estimates at full equilibrium. Line projection from the $\mathrm{Mg}$ apex through sample chemistry gives estimated geothermometer temperature $\left({ }^{\circ} \mathrm{C}\right)$ range on the chemically mature curve (Giggenbach, 1988).

realistic for a non-magmatic heat source geothermal system such as Lightning Dock. On the other had the $\mathrm{Na} / \mathrm{K}$ of Fournier (1979) and the $\mathrm{Na} / \mathrm{K} / \mathrm{Ca}$ show close agreement and probably show the maximum temperatures of the "deep" reservoir (152 to $168{ }^{\circ} \mathrm{C}$ ). The $\mathrm{Na} / \mathrm{Li}$ geothermometers of Fouillac and Michard 
(1981) do not appear be useful at Lightning Dock as these geothermometers are generally used for lower temperature geothermal systems $\left(<100^{\circ} \mathrm{C}\right)$. The $\mathrm{Na} / \mathrm{Li}$ geothermometer of Kharaka and others (1982) may predict "very deep or base" reservoir conditions; however, this geothermometer predicts temperatures 20 to $30{ }^{\circ} \mathrm{C}$ higher than other maximum cation geotemperatures and the quartz geothermometer. However, the $\mathrm{Na} / \mathrm{Li}$ geothermometer falls within the maximum temperatures indicated on the equilibrated or mature water line in the Giggenbach Ternary Diagram (Giggenbach, 1988) (Figure 4-10). The generally lower temperature $\mathrm{Mg} / \mathrm{Li}$ and $\mathrm{K} / \mathrm{Mg}$ geothermometers (132 to $173^{\circ} \mathrm{C}$ ) may reflect partial equilibrium conditions as shown in Figure 4-10. However, they generally bracket the minimum "deep" reservoir temperatures predicted by the quartz and the $\mathrm{Na} / \mathrm{K} / \mathrm{Ca}-\mathrm{Mg}$ (correction). A Cl/Br versus enthalpy may have use as a mixing model calculation of subsurface temperature (see Figure 4-3). This analysis was not done as sampling for $\mathrm{Cl} / \mathrm{Br}$ and $\mathrm{SiO}_{2}$ of additional Lightning Dock geothermal wells is probably needed.

\subsection{SYNTHESIS AND INTERPRETATION}

A limited, but up to date, geochemical analysis of chemistry, isotopic variation, and geothermometry of four geothermal wells at Lightning Dock, KGRA yields the following interpretations:

1) The shallow reservoir chemistry is sodium sulfate with total dissolved solids (TDS) between 1,000 and $1,180 \mathrm{mg} / \mathrm{L}$.

2) The waters appear to have mixed with groundwater at shallow depth and are not equilibrium with any silica phases except possibly chalcedony and do not show geochemical equilibrium maturity (Giggenbach Ternary).

3) Two end-member non-thermal groundwater mixes may be indicated by comparison of cation and isotopic ratios with the $\mathrm{CL} / \mathrm{Br}$ ratio. One end member may flow in from southeast (Pyramid Mountains) and the other may flow in from the southwest (Animas Valley). 
4) Minor water table boiling is possible at sample site AM3 because of isotopic fractionation of $\delta^{18} \mathrm{O}$ and $\delta \mathrm{D}$ (heavier) without a change in the $\mathrm{Cl} / \mathrm{Br}$ ratio of down gradient compositions at AM2.

5) The $\delta \mathrm{D}$ and $\delta^{18} \mathrm{O}$ show that the thermal waters represent old meteoric water that recharged in a cooler climate than today.

6) Isotopic information argues for an isolated flow path (reservoir and upflow zone) through silicic rocks such as granite and rhyolite and no reservoir chemical or isotopic equilibration with Paleozoic rocks (such as the Pennsylvanian Horquilla Formation) and basalts and andesite of Quaternary to Late Cretaceous age. The high ${ }^{87} \mathrm{Sr} /{ }^{86} \mathrm{Sr}$ ratios, depleted $\delta 13 \mathrm{C}$, and the relatively low values and small variation in $\mathrm{Cl} / \mathrm{Br}$ (compared to most geothermal waters) support this hypothesis.

7) The $\delta 34 S$ values show very little variation and may indicate a single source or mineral phase such as pyrite disseminated in mid-Tertiary rhyolite.

8) The minimum "deep" reservoir temperature ranges from 143 to $159^{\circ} \mathrm{C}$ and the maximum "deep" reservoir temperature most likely ranges from 152 to $\left.168^{\circ} \mathrm{C}\right)$

9)

\subsection{CONCLUSIONS AND DISCUSSION}

While many wells have been drilled at the Lightning Dock KGRA over the years, the subsurface geology of the area is not well defined. Recent studies of Witcher $2001 \mathrm{~b}$ and 2002 point to that the following factors are important to understanding the Lightning Dock geothermal system. An outflow plume, flowing north in silicified and fractured Tertiary Gila Conglomerate and Tertiary rhyolite and silicic ash flow tuff, underlies the tapered north end of the heat-flow anomaly (Witcher, 2002). The heat-flow anomaly occurs over a buried intra-basin horst block at the intersection of an incipient Pleistocene fault, the ring fracture zone of a mid-Tertiary ash flow tuff cauldron, and a major regional northwest-striking basement structure that shows major inversion tectonism (ie. normal faulting that is followed by reverse or transpressional faulting of the same structure zone) during the Mesozoic (Witcher, 1988, 2001b, and 2002). 
Previous geophysical studies and exploration efforts at Lightning Dock have used a simple Basin and Range fault zone model to explain the dynamics of the system. The Lightning Dock system is not contained in a major basin bounding fault zone. In fact, the Lightning Dock geothermal reservoir(s) is contained within a bedrock high or small intra graben horst block, at the intersection of four regional tectonic features: 1) a major WNW striking basement structure zone with repetitive compression and extensional deformation since Precambrian; 2) a mid-Tertiary caldera ring fracture zone; 3) a rift accommodation zone in the Animas graben complex: and 4) a small incipient and late Pleistocene normal fault that ends in the area of the thermal anomaly. The Pleistocene fault tip may enhance or open previous fracture permeability. The volcanic rocks drilled in the AmeriCulture AM-2 well place the geothermal system inside the mid-Tertiary Muir cauldron outer ring fracture. Ground water geochemical anomalies have been used to argue for a poorly defined northeasttrending feeder source for hot water. These geochemcal anomalies are probably the result of upwelling older deeper alluvial basin water over a bedrock high or constriction between the upper and lower Animas grabens as ground water flows southward, and not leakage from a high temperature "feeder zone" southwest of Lightning Dock.

Available geochemical information for the geothermal fluids suggests that the fluids have flowed through silicic rocks (Dellechaie, 1977). Low TDS and low bicarbonate concentration is not typical of hot water flow through limestone (ie Paleozoic carbonate rocks). This is an argument for three possibilities. First, a deep-seated basement (granite-metamorphic) circulation is implied. Second a "granite or rhyolite or silicic" uplflow channel is implied. Third, a long-term or periodic flow regime may also be assumed. In the paragenesis of the calcite vein zone (CVZ) at Lightning Dock Mountain the last two mineral phases were quartz. In other words, out flow from silicic basement may cross carbonate domains that have been silicified or jasperized by earlier late Tertiary or Quaternary hydrothermal systems. 
Field investigation of Miocene and Pliocene (?) hydrothermal fluorite and calcite veins (CVZ) at Lightning Dock Mountain indicates that a major fault may not be required for the upflow zone of the Lightning Dock thermal anomaly. The Tertiary hydrothermal veins at Lightning Dock Mountain have a nearly identical tectonic setting to the present day Lightning Dock geothermal system. A midTertiary Muir cauldron ring fracture rhyolite dike and flow complex may host the upflow zone at Lightning Dock. The juxtaposition of a WNW regional structure, a caldera ring fracture zone, and an intrabasin horst block (accommodation zone) points to intense fracturing and "ground preparation" to host outflow of geothermal water. Stress associated with the Pleistocene fault tip has locally opened older fractures. Upflow along a fractured Tertiary rhyolite dike in association with Pleistocene faulting and a rift accommodation zone is well characterized at Radium Springs, New Mexico (Witcher, 2001a)

Two stratigraphically controlled outflow plumes may exist at Lightning Dock. The shallow outflow plume is mostly contained in silicified and fractured Gila Conglomerate. Previous studies have erroneously interpreted the silicified Gila Conglomerate as "rhyolite." Limited deep outflow maybe is hosted the upper Jurassic to Lower Cretaceous rift fanglomerate (Hell-to-Finish Formation?) with solution and fracture permeability.

Heat flow and temperature gradient data indicate a total heat loss for the system less than $12 \mathrm{MWt}$ and a northward outflow (Witcher, 2001 and 2002). A base reservoir or upflow zone temperature of $160^{\circ} \mathrm{C}$ is determined from silica geothermometry and the temperature profile of the Steam Reserve Animas 55-7 well. A total natural mass flux of about $210 \mathrm{gpm}$ of water at $160^{\circ} \mathrm{C}$ into the base of the upflow zone is estimated by energy and mass balance of the Lightning Dock heat flow anomaly (Witcher, 2001b and 2002).

Drilling during GRED II studies confirms that the Lightning Dock geothermal system is structurally coincident with a buried, small intra-basin horst block that cross cuts the mid-Tertiary Muir cauldron outer ring fracture zone. The sequence of ash flow tuffs is interpreted to represent a Muir cauldron facies and the overlying biotite rhyolite may represent ring fracture zone flows or rhyolite 
dome. The intrusive source for the ring fracture zone rhyolite flow may provide the upflow path for the system. Temperature logs indicate the main outflow is within highly silicified Gila Conglomerate that is preserved on the top of the horst block. A probable paleosol at the top of the Gila Conglomerate sequence suggests that the horst block age is post Gila Conglomerate and that bounding faults have not been active since late Miocene or early Pliocene. Younger largely unaltered basin fill deposits buried the paleosol developed on the Gila Conglomerate on the uplift block.

Upper Jurassic- Lower Cretaceous sedimentary packages (Bisbee Group) drilled during GRED II confirmed the presence of a major WNW structural zone inferred from aeromagnetic data, Tertiary-Mesozoic subcrop relationships observed on the Paleozoic rocks between the Steam Reserve 55-7 and Cockrell Pyramid wells, and the close relative elevation of the Precambrian-Paleozoic contact between the 55-7 and Cockrell wells.

The 55-7 well subsurface geology and temperature logs indicate a deep outflow (about $150^{\circ} \mathrm{C}$ ) in the Bisbee Group. Temperature logs in the AM-2 well show that this deep outflow does not flow laterally to the north. It is believed that this deeper outflow probably leaks to the WNW into the older late Miocene to early Pliocene fault zone(s) bounding the west side of the buried horst block and then flows northward along the fault in fractures contained in the hanging wall Gila Conglomerate or Tertiary volcanics with possible minor upward leakage. The AmeriCulture Federal well (geochem sample AM4) probably overlies this deeper outflow as the AmeriCulture Federal well is west of the fault as determined by drawdown during a pump test of the AM-1 State well (Witcher, 2001b). The main upward leakage (upflow zone) is probably located in a rhyolite intrusion or WNW fracture (or shear) zone beneath the southeast portion of the Burgett greenhouse complex closest to the termination of the last surface break of the incipient Pleistocene Animas fault on the east side of the buried horst block. The deep basement structure of the WNW zone probably plays a role in the termination of the last surface break on the Pleistocene Animas fault and the south boundary of the Lightning Dock geothermal anomaly. 
Temperature logs and a short airlift test of the Horquilla Formation indicate elevated temperature but no permeability. Apparently, the sedimentation of the Bisbee Group rift deposits were not preceded by significant karst (solution permeability) development within the underlying Paleozoic carbonate rocks. This is consistent with geochemical evidence that precludes flow (and chemical equilibrium) with Paleozoic limestone for the geothermal fluids at Lightning Dock. The elevated temperatures represent a thermal areole around the upflow. The roll over in shallow temperature logs would indicate that the shallow outflow has relatively young geologic age. The larger thermal areole suggests an over all longer lived system (in the last $1 \mathrm{Ma}$ ) that is periodically very active (10's Ka) at a shallower depth. The relationships of fluorite mineralization and a fairly wide belt of hydrothermal calcite in the Pyramid Mountains to the east indicates that the regional WNW zones can be active at tectonically favorable locations on the order of several Ma intervals. Table Top Mountain may represent another.

The conclusions drawn from the GRED II drilling is that while many details of the Lightning Dock geothermal system remain to be determined, the system is relatively small, is relatively long-lived with periodic spurts in activity, has deep flow roots in either Precambrian "granite" or mid-Tertiary rhyolite cauldron complexes along a WNW-trending regional structural weakness. An incipient Pleistocene fault zone (Animas Fault) serves to open up deep-seated flow in these rocks. The upflow is probably a contained in a small window of vertical permeability opened by the Pleistocene fault that ends at the deep-seated WNW shear zone. A Muir cauldron ring fracture zone rhyolite intrusive contained within a small-buried horst block maybe cross cut by the Pleistocene fault zone to provide the vertical permeability window. The major shallow outflow is within a remnant Gila Conglomerate section preserved at the top of the horst block and minor deep outflow may be channeled first by permeable WNW fractures in Bisbee Group sediments in the horst block that are connected to inactive Miocene to Pliocene fault zones with remnant permeability on the west side of the horst block. In any case, the flow system is predominantly contained in midTertiary rhyolite or detritus derived from the mid-Tertiary rhyolite (Gila 
Conglomerate) at shallow and intermediate depth and either Precambrian granite or mid-Tertiary plutons at great depth. There is no productive reservoir present in either the Mesozoic or Paleozoic rocks beneath Lightning Dock.

\subsection{REFERENCES}

Algeo, T. J., 1996, Meteoric water/rock ratios and the significance of sequence and parasequence boundaries in the Gobbler Formation (Middle Pennsylvanian) of south-central New Mexico, in Witzke, B. J., Ludvigson, G. A., and Daly, J., eds., Paleozoic Sequence Stratigraphy: Views from the North American Craton: Geological Society of America Special Paper 306, p. 359-371.

Banner, J.L., Wasserburg, G. J., Dobson, P. F., Carpenter, A. B., and Moore, C.H., 1989. Isotopic and trace element constraints on the origin and evolution of saline groundwaters from central Missouri: Geochimica et Cosmochimica Acta, v. 53, p. 383-398.

Bayona, G., and Lawton, T. F., 2000, Aptian-Albian extensional faulting and subsequent Laramide inversion, central Peloncillo Mountains, southwestern New Mexico: New Mexico Geological Society $51^{\text {st }}$ Field Conference Guidebook, p. 85-94.

Bethke, C.M., 1996, Geochemical Reaction Modeling: New York, Oxford University Press, 397 p.

Burke, W. H., Denison, R. E., Hetherington, E. A., Koepnick, R. B., Nelson, H. F., and Otto, J. B., 1982, Variation of seawater ${ }^{87} \mathrm{Sr} /{ }^{86} \mathrm{Sr}$ throughout Phanerozoic time: Geology, v. 10, p. 516-519.

Butcher, D. P., 1990, Geochemistry and Nd-Sr systematics of selected lithologic units of the Oligocene Organ cauldron and batholith, south central New Mexico: unpub. M. S. Thesis, New Mexico State University, Las Cruces, $145 \mathrm{p}$.

Capo, R. C., Stewart, B. W., and Chadwick, O. A., 1998, Strontium isotopes as tracers of ecosystem processes theory and methods: Geoderma, v. 82, p. 197-225.

Cas, R. A. F., and Wright, J. V., 1988, Volcanic Successions Modern and Ancient: Chapman and Hall, London, 528 p.

Clark, I. and Fritz, P., 1997, Environmental Isotopes in Hydrogeology: New York, Lewis Publishers. $328 \mathrm{p}$. 
Condie, K. C., and Budding, A. J., 1979, Geology and geochemistry of Precambrian rocks, central and south-central New Mexico: New Mexico Bureau of Mines and Mineral Resources Memoir 35, p. 58.

Craig, H., 1961, Isotopic variations in meteoric waters: Science, v. 133, p. 17021703.

Cunniff, R. A., and Bowers, R. L., 1988, Temperature, water chemistry, and lithological data for the Lightning Dock Known Geothermal Resources Area, Animas Valley, New Mexico, in Icerman, L., and Parker, S. K., eds., New Mexico Statewide Geothermal Program: New Mexico Research and Development Institute, p. 3-1 to 3-37.

Dansgaard, W. 1964, Stable isotopes in precipitation: Tellus, v. 16, p. 461-469.

Davis, S. N., Whittemore, D. O., and Fabyka-Martin, J., 1998, Uses of chloride/bromide ratios in studies of potable water: Ground Water, v. 36, no. 2, p. 338-350.

Dellechaie, F., 1977, A geological and hydrochemical study of the Animas geothermal area, Hidalgo County, New Mexico: Transactions, Geothermal Resources Council, v. 1, p. 73-75.

Elston, W. E., 1976, Tectonic significance of mid-Tertiary volcanism in the Basin and Range Province a critical review with special reference to New Mexico, in Elston, W. E., and Northrop, S. A., eds., Cenozoic Volcanism in Southwestern New Mexico: New Mexico Geological Society Special Publication 5, p. 93-102.

Elston, W. E., Deal, E. G., and Logsdon, M. J., 1983, Geology and geothermal waters of Lightning Dock Region, Animas Valley and Pyramid Mountains, Hidalgo County, New Mexico: New Mexico Bureau of Mines and Mineral Resources Circular 177, $44 \mathrm{p}$.

Faure, G., 1986, Principles of Isotope Geology: John Wiley and Sons, Inc., New York, $589 \mathrm{p}$.

Fontes, J. -Ch., 1980, Environmental isotopes in groundwater hydrology, in Fritz, P. and Fontes, J. -Ch., eds, Handbook of Environmental Isotope Geochemistry, Volume 1, The Terrestrial Environment: Elsevier, New York, p. 75-140.

Fouillac, C. and Michard, G., 1981, Sodium/lithium ratio in water applied to geothermometry of geothermal reservoirs: Geothermics, v. 10, no.1, p. 5570 . 
Fournier, R. O., 1960, Solubility of quartz in water in the temperature interval from $25{ }^{\circ} \mathrm{C}$ to $300{ }^{\circ} \mathrm{C}$ : Geological Society of America Bulletin, v. 71, p. 1867-1868.

Fournier, R. O., 1977, Chemical geothermometers and mixing models for geothermal systems: Geothermics, v. 5, p. 41-50.

Fournier, R. O., 1979, A revised equation for the $\mathrm{Na} / \mathrm{K}$ geothermometer: Transactions, Geothermal Resources Council, v. 3, p. 221-224.

Fournier, R. O., and Potter, R. W., 1979, Magnesium correction to the Na-K-Ca chemical geothermometer: Geochim et Cosmochim Acta, v. 43, p. 15431550.

Fournier, R. O., and Truesdell, A. H., 1973, An empirical Na-K-Ca geothermometer fro natural waters: Geochim et Cosmochim Acta, v. 37, p. $1255-1275$.

Fournier, R. O., White, D. E., and Truesdell, A. H., 1974, Geochemical indicators of subsurface temperature, 1. Basic assumptions: Journal of Research, U. S. Geological Survey, v. 2, no. 3, p. 259-262.

Gat, J. R., 1996, Oxygen and hydrogen isotopes in the hydrologic cylcle: Annual Review of Earth and Planetary Sciences, v. 24, p. 225-262.

Giggenbach, W. F., 1988, Geothermal solute equilibria. Derivation of Na-K-MgCa geoindicators: Geochim et Cosmochim Acta, v. 52, p. 2749-2765.

Gile, L. H., Hawley, J. W., and Grossman, R. B., 1981, Soils and geomorphology in the Basin and Range area of southern New Mexico - Guidebook to the Desert Project: New Mexico Bureau of Mines and Mineral Resources Memoir 39,222 p.

Hanor, J. S., 1988, Origin and migration of subsurface sedimentary brines: Society of Economic Paleontologists and Mineralogists Short Course 21, $247 \mathrm{p}$.

Hanor, J. S., 1994, Origin of saline fluids in sedimentary basins, in Parnell, J., ed., Geofluids: Origin, Migration and Evolution of Fluids in Sedimentary Basins: Geological Society Special Publication 78, p. 151-174. 
Hawley, J.W., Hibbs, B.J., Kennedy,J.F.,Creel, B.J., Remmenga, M.D., M. Johnson,M.,Lee, J., and Dinterman, P., 2000, Trans-International Boundary aquifers in southwestern New Mexico: New Mexico Water Resources Research Institute, New Mexico State University, prepared for U.S. Environmental Protection Agency-Region 6 and International Boundary and Water Commission, Technical Completion Report Interagency Contract X-996350-01-3, $126 \mathrm{p}$.

Hem, J.D., 1985, Study and interpretation of the chemical characteristics of natural water: U.S. Geological Survey Water-Supply Paper 2254, 263 p.

Hibbs, B. J., M.M. Lee, J.W. Hawley and J.F. Kennedy, 2000, Some notes on the hydrogeology and ground-water quality of the Animas Basin system. Southwestern New Mexico: New Mexico Geological Society, $51^{\text {st }}$ Annual Field Conference Guidebook, p 227-234.

Hill, C. A., 1996, Geology of the Delaware basin, Guadalupe, Apache, and Glass Mountains, New Mexico and West Texas: Permian Basin Section, Society of Economic Paleontologists and Mineralogists Publication 96-39, 480 p.

Hoefs, J., 1997, Stable Isotope Geochemistry: Springer-Verlag, Berlin, p. 308.

Hounslow, A. W., 1995, Water quality data analysis and interpretation: Lewis Publishers, Boca Raton, 397 p.

Jaeger, J. C., 1984, Thermal effects of intrusions: Reviews Gephysics, v. 2, p. 443-466.

Johnson, T.M., and D.J. Depaolo, D.J., 1994, Interpretation of isotopic data in groundwater-rock systems, model development and application to $\mathrm{Sr}$ isotope data from Yucca Mountain: Water Resources Research, v. 30 no.5 p. 1571-1587.

Kharaka, Y. K., Lico, M. S., and Law, L. W., 1982, Chemical geothermometers applied to formation waters, Gulf of Mexico and California Basins (abs): American Association of Petroleum Geologists Bulletin, 66, p. 588.

Kharaka, Y. K., and Mariner, R. H., 1988, Chemical geothermometers and their application to formation waters from sedimentary basins, in Naser, N. D., McCollin, T. H., eds., Thermal History of Sedimentary Basins: SpringerVerlag, New York, p. 99-117.

Kucks, R. P., Hill, P. L., and Heywood, C. E., 2001, New Mexico areomagnetic and gravity maps and data: a website for distribution of data: U. S. Geological Survey Open-File Report 01-006, web address; http:IIgreenwood.cr.usgs.gov/pub/open-file-reports/ofr-01-0061/html/nm 4014.htm. 
Lawton, T. F., 2000, Inversion of Late Jurassic-Early Cretaceous extensional faults of the Bisbee Basin, southeastern Arizona and southwestern New Mexico: New Mexico Geological Society $51^{\text {st }}$ Field Conference Guidebook, p. $95-102$.

Logsdon, M. J., 1981, The aqueous geochemistry of the Lightning Dock Known Geothermal Resource Area, Animas Valley, Hidalgo County, New Mexico: unpublished M. S. Thesis, University of New Mexico, Albuquerque, 239 p.

Mack, G. H., Cole, D. R., James, W. C., Giordano, T. H., and Salyards, S. L., 1994, Stable oxygen and carbon isotopes of pedogenic carbonate as indicators of Plio-Pleistocene paleoclimate in the southern Rio Grande rift, south-central New Mexico: American Journal of Science, v. 284, p. 621640.

Mack, G. H., Cole, D. R., and Trevino, L., 2000, The distribution and discrimination of shallow, authigenic carbonate in the PliocenePleistocene Palomas Basin, southern Rio Grande rift: Geological Society of America Bulletin, v. 112, no. 5, p. 643-656.

Mazor, E., 1997, Chemical and Isotopic Groundwater Hydrology: New York: Marcel Dekker, Inc. 413 p.

McArthur, J. M., Howarth, R. J., and Bailey, T. R., 2001, Strontium isotope stratigraphy: LOWESS version 3: best fit to the marine Sr-isotope curve for 0-509 $\mathrm{Ma}$ and accompanying look-up table for deriving numerical age: The Journal of Geology, v.109, p. 155-170.

Mclntosh, W. C., and Bryan, C., 2000, Chronology and geochemistry of the Boot Heel volcanic field, New Mexico: New Mexico Geological Society $51^{\text {st }}$ Field Conference Guidebook, p. 157-174.

McPhie, J., Doyle, M., and Allen, R., 1993, Volcanic Textures: Center for Ore Deposit and Exploration Studies, University of Tasmania, 198 p.

Monger, H. C., Cole, D. R., Gish, J. W., and Giordano, T. H., 1998, Stable carbon and oxygen isotopes in Quaternary soil carbonates as indicators of ecogeomorphic changes in the northern Chihuahuan Desert, USA: Geoderma, v. 82, p. 137-172.

Nicholson, K., 1993, Geothermal Fluids Chemistry and Exploration Techniques: Springer-Verlag, Berlin, p. 263. 
Norman, D. E., and Bernhardt, C. A., 1982, Assessment of geothermal reservoirs by analysis of gases in thermal waters: New Mexico Research and Development Institute Report EMD 2-68-2305, 130 p.

O'Brien, K. M., and Stone, W. J., 1982, Water-quality data compiled for hydrogeologic study of Animas Valley, Hidalgo County, New Mexico: New Mexico Bureau of Mines and Mineral Resources Open-File Report 131, 25 p.

O'Brien, K. M., and Stone, W. J., 1983, A two dimensional hydrologic model of the Animas Valley, Hidalgo County, New Mexico: New Mexico Bureau of Mines and Mineral Resources Open-File Report 133, 63 p.

O'Brien, K. M., and Stone, W. J., 1984, Role of geological and geophysical dat in modeling a southwestern alluvial basin: Ground Water, v. 22, no. 6, p. 717-727.

Piper, A. M., 1944, A graphic procedure in the geochemical interpretation of water-analyses: Transactions, American Geophysical Union, v. 25, p. 914923.

Reed, M.J. and Mariner R.H., 1991, Quality control of chemical and isotopic analyses of geothermal water samples: Proceedings, Sixteenth Workshop on Geothermal Reservoir Engineering,Stanford Geothermal Program Workshop Report SGP-TR-134. p. 9-13.

Rimstidt, J. D. and Barnes, H. L., 1980, The kinetics of silica-water reactions: Geochimica et Cosmochimica Acta, v. 44, p. 1683-1700.

Smith, C., 1978, Geophysics, geology, and geothermal leasing status of the Lightning Dock KGRA, Animas Valley, New Mexico: New Mexico Geological Society, $29^{\text {th }}$ Annual Field Conference Guidebook, p. 343-348.

Smith, R. L., and Shaw, H. R., 1975, Igneous-related geothermal systems, in White, D. F., and Williams, D. F., eds., Assessment of Geothermal Resources of the United States-1975: U. S. Geological Survey Circular 726 , p. $58-83$.

Stanton, R. J., Jeffery, D. L., and Ahr, W. M., 2002, Early Mississippian climate based on oxygen isotope compositions of brachiopods, Alamogordo Member of the Lake Valley Formation, south-central New Mexico: Geological Society of America Bulletin, v. 114, no. 1, p. 4-11.

Stewart, B. W., Capo, R. C., and Chadwick, O. A., 1998, Quantitative strontium isotope models for weathering, pedogenesis and biochemical cycling: Geoderma, v. 82, p. 173-195. 
Swanberg, C. A., Morgan, P., Stoyer, C. H., and Witcher, J. C., 1977, An appraisal study of the geothermal resources of Arizona and adjacent areas in New Mexico and Utah and their value for desalination and other uses: New Mexico Energy Institute Report NMEI 6, 76 p.

Thode, H. G., and Monster, J., 1965, Sulfur-isotope geochemistry of petroleum, evaporites, and ancient seas, in Young, A., and Galley, J. E., eds., Fluids in the Subsurface Environment: American Association of Petroleum Geologists Memoir 4, p. 367-377.

Van der Hoven, S. J., 1994, Strontium isotopes as an indicator of the sources of calcium in secondary carbonates in an arid environment: Unpublished. M. $\mathrm{S}$. Thesis, University of Arizona, Tucson, $51 \mathrm{p}$.

Veizer, J., Ala, D., Azmy, K., Bruckshen, P., Buhl, D., Bruhn, F., Carden, G. A. F., Diener, A., Enbeth, S., Godderis, Y., Jasper, T., Korte, C., Pawellek, F., Podlaha, O. G., and Strauss, $\mathrm{H} .,{ }^{87} \mathrm{Sr} /{ }^{86} \mathrm{Sr}, \delta^{13} \mathrm{C}$, and $\delta^{18} \mathrm{O}$ evolution of Phanerozoic seawater: Chemical Geology, v. 161, p. 59-88.

Vuataz, F. D., and Goff, F., 1986, Isotope geochemistry of thermal and thermal waters in the Valles Caldera, Jemez Mountains, northern New Mexico: Journal of Geophysical Research, v. 91, no. B2, p. 1835-1853.

Witcher, J.C., 1988, Geothermal resources of southwestern New Mexico: New Mexico Geological Society, $39^{\text {th }}$ Annual Field Conference Guidebook, p. 191-197.

Witcher, J. C. 2001a, Geothermal direct-use well for commercial greenhouses Radium Springs, New Mexico: Oregon Institute of Technology, Geo-Heat Center Quarterly Bulletin, v. 22, no. 4, p. 1- 7.

Witcher, J. C., 2001b, A preliminary analysis of the shallow reservoir characteristics of the Lightning Dock geothermal system as determined from pump test of AmeriCulture 1 State production well: Technical Completion Report submitted to AmeriCulture, Inc., Cotton City, NM, 39 p.

Witcher, J. C. , 2002, AmeriCulture EGS-1 characterization well geologic log and a preliminary geologic analysis of the Lightning Dock geothermal system: Technical Completion Report submitted to AmeriCulture,Inc., Cotton City, NM, $37 \mathrm{p}$.

Witcher, J. C., King, J. P., Hawley, J. W., Kennedy, J. F., Williams, J., Cleary, M., and Bothern, L. R., 2004, Sources of salinity in the Rio Grande and Mesilla Basin groundwater: New Mexico Water Resources Research Institute Technical Report 330, 168 p. 


\section{APPENDIX 1 SUMMARY GEOLOGIC LOG}

\begin{tabular}{|c|c|c|}
\hline \multicolumn{3}{|c|}{ SUMMARY GEOLOGIC LOG - AmeriCulture State 2} \\
\hline TOP & BOTTOM & FORMATION \\
\hline $\mathbf{f t}$ & $\mathrm{ft}$ & lithology, unit, age, structure \\
\hline 0 & 270 & Upper basin fill alluvium (Quaternary-Tertiary) \\
\hline 270 & 284 & Paleosoil (?) top of Gila Conglomerate (Tertiary) \\
\hline 284 & 570 & Gila Conglomerate (highly silicified) (Tertiary) \\
\hline 570 & 645 & Conglomerate (caldera moat fill ?) (Tertiary) \\
\hline 645 & 730 & Altered biotite rhyolite (ring fracture flow or dike) (Tertiary) \\
\hline 730 & 830 & Vitrophyric biotite rhyolite (ring fracture flow or dike (Tertiary) \\
\hline 830 & 860 & Altered biotite rhyolite (ring fracture flow or dike) (Tertiary) \\
\hline 860 & 958 & Rhyolite ash flow tuff (upper cauldron fill) (Tertiary) \\
\hline 958 & 1105 & Rhyolite lithic ash flow tuff (lower cauldron fill) (Tertiary) \\
\hline 1105 & 1145 & Volcanic mud flow (lahar) (Tertiary) \\
\hline 1145 & 1151 & Matrix-supported volcanic gravel (Tertiary) \\
\hline \multirow[t]{2}{*}{1151} & 1212 & Tuffaceous volcaniclastics and interbedded ash flow tuff \\
\hline & & (Tertiary?) (fault zone 1169 to $1175 \mathrm{ft}$ ) \\
\hline \multirow[t]{2}{*}{1212} & 1238 & Sandy boulder to gravel volcaniclastics (Tertiary?) \\
\hline & & (fault zone 1255 to $1275 \mathrm{ft}$, dip about $60^{\circ}$ ) \\
\hline 1238 & 1296 & Tuffaceous sandy volcaniclastics (Tertiary?) \\
\hline 1296 & 1326 & Pumaceous mud flow (Tertiary?) \\
\hline \multirow[t]{2}{*}{1326} & 1334 & Porphyritic andesite (Late Cretaceous? Tertiary?) \\
\hline & & (fault zone at 1334 to $1344 \mathrm{ft}$, dip $35^{\circ}$ to $40^{\circ}$ ) \\
\hline \multirow[t]{3}{*}{1334} & 1456 & Interbedded calcareous sandstone, calcareous shale, shale, \\
\hline & & and dolomite (Early Cretaceous) Bisbee Group \\
\hline & & (fault zone at 1392 to $1397 \mathrm{ft}$, dip $35^{\circ}$ to $40^{\circ}$ ) \\
\hline \multirow[t]{3}{*}{1456} & 1653 & Lithified sandy limestone cobble-to-boulder clast-supported \\
\hline & & conglomerate (Early Cretaceous) Bisbee Group \\
\hline & & (fault zone 1594 to $1607 \mathrm{ft}$, dip about $60^{\circ}$ ) \\
\hline 1653 & 1850 & Limestone (Paleozoic) Horquilla Formation \\
\hline \multirow[t]{2}{*}{1850} & 1990 & Dacite, porphyritic dacite, and dacite porphyry \\
\hline & & (Tertiary ? sill or dike) \\
\hline 1990 & 2030 & Limestone (Paleozoic) Horquilla Formation \\
\hline \multirow[t]{2}{*}{2030} & 2100 & Interbedded fine sandstone and siltstone (Paleozoic) \\
\hline & & Horquilla Formation \\
\hline
\end{tabular}




\section{APPENDIX 2 CORE RUN LOG}

\begin{tabular}{|c|c|c|c|c|c|c|c|c|c|}
\hline CORE & DATE & BEGIN & END & TIME & TOP & Воттом & DRILLED & CORE & REMARKS \\
\hline RUN & & hrs & hrs & $\min$ & $\mathrm{ft}$ & $\mathrm{ft}$ & $\mathrm{ft}$ & $\mathrm{ft}$ & \\
\hline 1 & 13-Aug & 1945 & 2010 & 25 & 906.5 & 912.5 & 6.0 & 6.0 & \\
\hline 2 & & 2030 & 2050 & 20 & 812.5 & 917.5 & 5.0 & 4.3 & \\
\hline 3 & & 2117 & 2247 & 30 & 918.5 & 927.5 & 10.0 & 10.0 & \\
\hline 4 & & 2303 & 2333 & 30 & 927.5 & 937.5 & 10.0 & 10.0 & \\
\hline 5 & 14-Aug & 0056 & 0122 & 26 & 937.5 & 947.5 & 10.0 & 10.0 & \\
\hline 6 & & 0208 & 0306 & 58 & 947.5 & 957.5 & 10.0 & 10.0 & BHT $184^{\circ} \mathrm{F}$ \\
\hline 7 & & 0401 & 0429 & 28 & 957.5 & 967.5 & 10.0 & 10.0 & \\
\hline 8 & & 0500 & 0526 & 26 & 967.5 & 977.5 & 10.0 & 10.0 & \\
\hline 9 & & 0615 & 0637 & 22 & 977.5 & 987.5 & 10.0 & 10.0 & \\
\hline 10 & & 0720 & 0741 & 21 & 987.5 & 997.5 & 10.0 & 10.0 & \\
\hline 11 & & 0802 & 0825 & 23 & 997.5 & 1007.5 & 10.0 & 10.0 & \\
\hline 12 & & 0846 & 0919 & 33 & 1007.5 & 1017.5 & 10.0 & 10.0 & \\
\hline 13 & & 0942 & 1014 & 32 & 1017.5 & 1027.5 & 10.0 & 10.0 & $\mathrm{BHT} 204^{\circ} \mathrm{F}$ \\
\hline 14 & & 1045 & 1118 & 33 & 1027.5 & 1037.5 & 10.0 & 10.0 & \\
\hline 15 & & 1144 & 1215 & 31 & 1037.5 & 1047.5 & 10.0 & 10.0 & \\
\hline 16 & & 1305 & 1340 & 35 & 1047.5 & 1057.5 & 10.0 & 10.0 & \\
\hline 17 & & 1420 & 1458 & 38 & 1057.5 & 1067.5 & 10.0 & 10.0 & \\
\hline 18 & & 1530 & 1618 & 48 & 1067.5 & 1077.5 & 10.0 & 10.0 & \\
\hline 19 & & 1715 & 1750 & 35 & 1077.5 & 1087.5 & 10.0 & 10.0 & \\
\hline 20 & & 1839 & 2022 & 36 & 1087.5 & 1097.5 & 10.0 & 10.0 & \\
\hline 21 & & 1950 & 2322 & 32 & 1097.5 & 1107.5 & 10.0 & 8.0 & BHT $210^{\circ} \mathrm{F}$ \\
\hline 22 & & 2255 & 0245 & 37 & 1107.5 & 1117.5 & 10.0 & 10.8 & \\
\hline 23 & 15-Aug & 0210 & 0425 & 35 & 1117.5 & 1120.5 & 3.0 & 3.0 & \\
\hline 24 & & 0325 & 0600 & 60 & 1120.5 & 1127.5 & 7.0 & 6.7 & \\
\hline 25 & & 0540 & 0710 & 20 & 1127.5 & 1129.5 & 2.0 & 2.0 & \\
\hline 26 & & 0650 & 0825 & 20 & 1129.5 & 1137.5 & 8.0 & 8.0 & \\
\hline 27 & & 0745 & 0915 & 40 & 1137.5 & 1147.5 & 10.0 & 10.0 & $\mathrm{BHT} 210^{\circ} \mathrm{F}$ \\
\hline 28 & & 0928 & 1002 & 30 & 1147.5 & 1157.5 & 10.0 & 8.5 & \\
\hline 29 & & 1032 & 1118 & 50 & 1157.5 & 1167.5 & 10.0 & 10.0 & \\
\hline 30 & & 1305 & 1348 & 43 & 1167.5 & 1177.5 & 10.0 & 10.0 & \\
\hline 31 & & 1423 & 1520 & 63 & 1177.5 & 1187.5 & 10.0 & 10.0 & \\
\hline 32 & & 1625 & 1650 & 25 & 1187.5 & 1197.5 & 10.0 & 10.0 & $\mathrm{BHT} 216^{\circ} \mathrm{F}$ \\
\hline 33 & & 1741 & 1810 & 31 & 1197.5 & 1207.5 & 10.0 & 10.0 & \\
\hline 34 & & 1835 & 1903 & 32 & 1207.5 & 1217.5 & 10.0 & 10.0 & \\
\hline 35 & & 1923 & 1946 & 23 & 1217.5 & 1227.5 & 10.0 & 10.0 & \\
\hline 36 & & 2004 & 2038 & 34 & 1227.5 & 1237.5 & 10.0 & 10.0 & \\
\hline 37 & & 2055 & 2120 & 25 & 1237.5 & 1247.5 & 10.0 & 10.0 & BHT $221^{\circ} \mathrm{F}$ \\
\hline 38 & & 2142 & 2208 & 20 & 1247.5 & 1257.5 & 10.0 & 10.0 & \\
\hline 39 & & 2227 & 2255 & 32 & 1257.5 & 1264.0 & 6.5 & 6.5 & \\
\hline 40 & & 2328 & 2354 & 26 & 1264.0 & 1274.5 & 10.5 & 10.5 & \\
\hline 41 & 16-Aug & 0219 & 0249 & 30 & 1274.5 & 1285.0 & 10.5 & 10.5 & \\
\hline 42 & & 0312 & 0345 & 33 & 1285.0 & 1295.5 & 10.5 & 10.5 & BHT $200^{\circ} \mathrm{F}$ \\
\hline
\end{tabular}




\begin{tabular}{|c|c|c|c|c|c|c|c|c|c|}
\hline 43 & & 0428 & 0502 & 34 & 1295.5 & 1306.0 & 10.5 & 10.5 & \\
\hline 44 & & 0530 & 0605 & 35 & 1306.0 & 1316.5 & 10.5 & 10.5 & \\
\hline 45 & & 0640 & 0717 & 37 & 1316.5 & 1327.0 & 10.5 & 10.5 & \\
\hline 46 & & 0801 & 0825 & 24 & 1327.0 & 1337.5 & 10.5 & 10.5 & \\
\hline 47 & & 0845 & 0910 & 25 & 1337.5 & 1347.5 & 10.0 & 5.0 & \\
\hline 48 & & 0930 & 0947 & 24 & 1347.5 & 1353.0 & 5.5 & 10.5 & BHT $214^{\circ} \mathrm{F}$ \\
\hline 49 & & 1010 & 1032 & 22 & 1353.0 & 1363.5 & 10.5 & 10.5 & \\
\hline 50 & & 1055 & 1125 & 30 & 1363.5 & 1373.5 & 10.0 & 10.0 & \\
\hline 51 & & 1147 & 1218 & 31 & 1373.5 & 1384.0 & 10.5 & 10.5 & \\
\hline 52 & & 1253 & 1325 & 32 & 1384.0 & 1394.5 & 10.5 & 10.5 & \\
\hline 53 & & 1350 & 1430 & 40 & 1394.5 & 1405.0 & 10.5 & 10.5 & \\
\hline 54 & & 1500 & 1530 & 30 & 1405.0 & 1415.5 & 10.5 & 10.5 & \\
\hline 55 & & 1558 & 1630 & 32 & 1415.5 & 1426.0 & 10.5 & 10.5 & BHT $220^{\circ} \mathrm{F}$ \\
\hline 56 & & 1650 & 1730 & 40 & 1426.0 & 1436.5 & 10.5 & 10.5 & \\
\hline 57 & & 1745 & 1818 & 33 & 1436.5 & 1447.0 & 10.5 & 10.5 & \\
\hline 58 & & 1841 & 1912 & 31 & 1447.0 & 1457.5 & 10.5 & 10.5 & \\
\hline 59 & & 1925 & 2006 & 31 & 1457.5 & 1467.5 & 10.0 & 10.0 & \\
\hline 60 & & 2032 & 2120 & 52 & 1467.5 & 1477.5 & 10.0 & 10.0 & $\mathrm{BHT} 226^{\circ} \mathrm{F}$ \\
\hline 61 & & 2145 & 2218 & 33 & 1477.5 & 1480.0 & 2.5 & 2.5 & \\
\hline 62 & & 2230 & 2240 & 10 & 1480.0 & 1481.0 & 1.0 & 1.0 & \\
\hline 63 & 17-Aug & 0700 & 0805 & 65 & 1481.0 & 1487.5 & 6.5 & 6.5 & \\
\hline 64 & & 0818 & 0925 & 67 & 1487.5 & 1497.5 & 10.0 & 10.0 & \\
\hline 65 & & 0950 & 1117 & 87 & 1497.5 & 1507.5 & 10.0 & 10.0 & \\
\hline 66 & & 1153 & 1253 & 60 & 1507.5 & 1517.5 & 10.0 & 10.0 & \\
\hline 67 & & 1326 & 1430 & 64 & 1517.5 & 1527.0 & 9.5 & 9.5 & \\
\hline 68 & & 2020 & 2125 & 65 & 1527.0 & 1529.0 & 2.0 & 2.0 & \\
\hline 69 & 18-Aug & 0920 & 1020 & 60 & 1529.0 & 1537.5 & 8.5 & 8.5 & \\
\hline 70 & & 1048 & 1140 & 52 & 1537.5 & 1547.5 & 10.0 & 10.0 & BHT $206^{\circ} \mathrm{F}$ \\
\hline 71 & & 1242 & 1402 & 20 & 1547.5 & 1557.5 & 10.0 & 10.0 & \\
\hline 72 & & 1432 & 1556 & 84 & 1557.5 & 1567.5 & 10.0 & 10.0 & lost circulation \\
\hline 73 & & 1615 & 1715 & 60 & 1567.5 & 1577.5 & 10.0 & 10.0 & lost circulation \\
\hline 74 & & 1743 & 1912 & 89 & 1577.5 & 1587.5 & 10.0 & 10.0 & lost circulation \\
\hline 75 & & 1940 & 2050 & 70 & 1587.5 & 1597.5 & 10.0 & 10.0 & BHT $218^{\circ} \mathrm{F}$; lost circulation \\
\hline 76 & & 2122 & 2222 & 60 & 1597.5 & 1607.5 & 10.0 & 10.0 & lost circulation \\
\hline 77 & & 2240 & 2330 & 50 & 1607.5 & 1617.5 & 10.0 & 10.0 & lost circulation \\
\hline 78 & 19-Aug & 0040 & 0145 & 65 & 1617.5 & 1627.5 & 10.0 & 10.0 & lost circulation \\
\hline 79 & & 1042 & 1265 & 83 & 1627.5 & 1637.5 & 10.0 & 10.0 & lost circulation \\
\hline 80 & & 1307 & 1427 & 80 & 1637.5 & 1647.5 & 10.0 & 10.0 & lost circulation \\
\hline 81 & & 1456 & 1550 & 66 & 1647.5 & 1657.5 & 10.0 & 10.0 & lost circulation \\
\hline 82 & & 1609 & 1718 & 69 & 1657.5 & 1667.5 & 10.0 & 10.0 & lost circulation \\
\hline 83 & & 1737 & 1810 & 93 & 1667.5 & 1657.5 & 10.0 & 10.0 & lost circulation \\
\hline 84 & & 1930 & 2103 & 93 & 1667.5 & 1687.5 & 10.0 & 10.0 & lost circulation \\
\hline
\end{tabular}


APPENDIX 3 DAILY DRILLING REPORT LOG

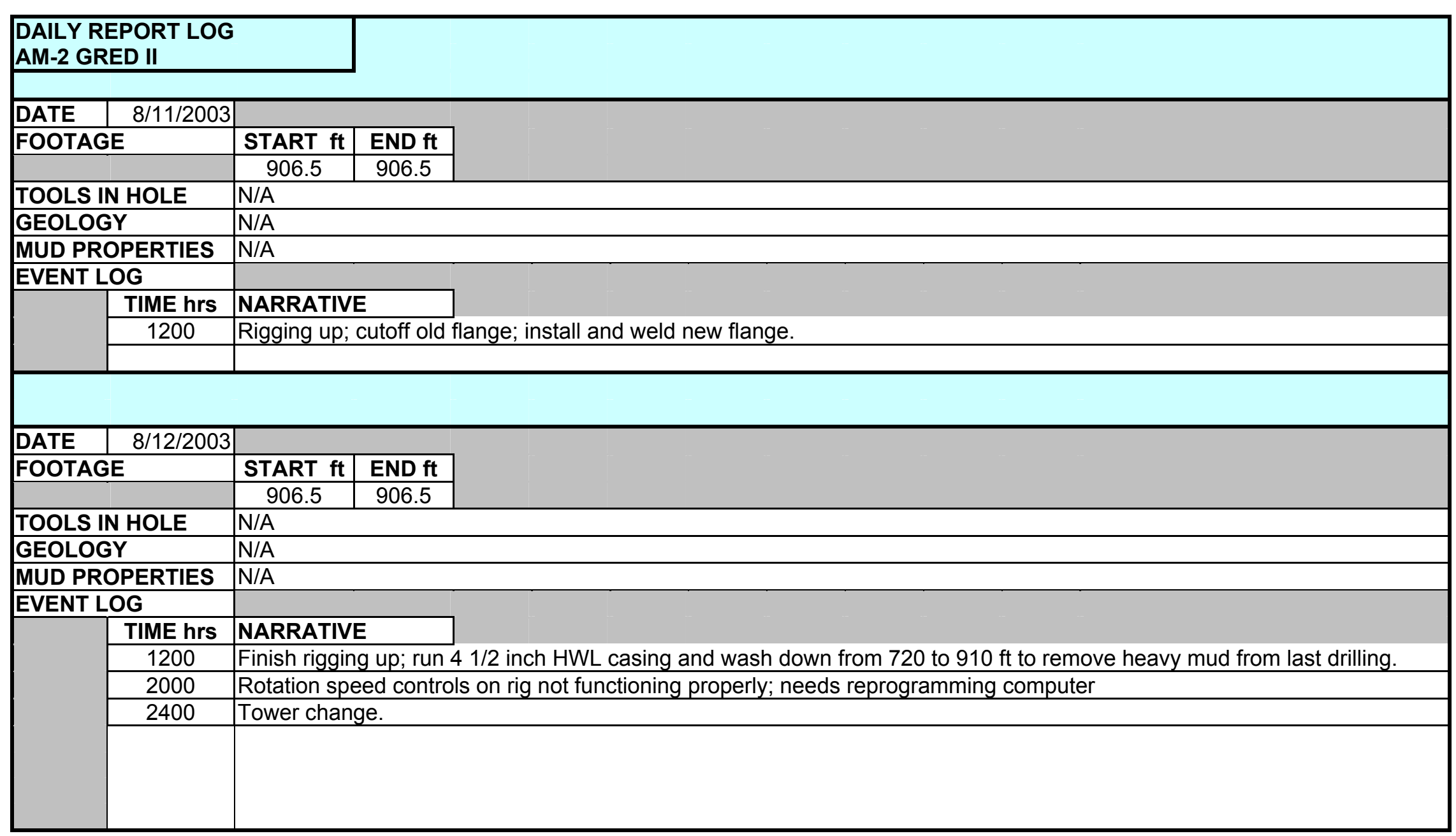




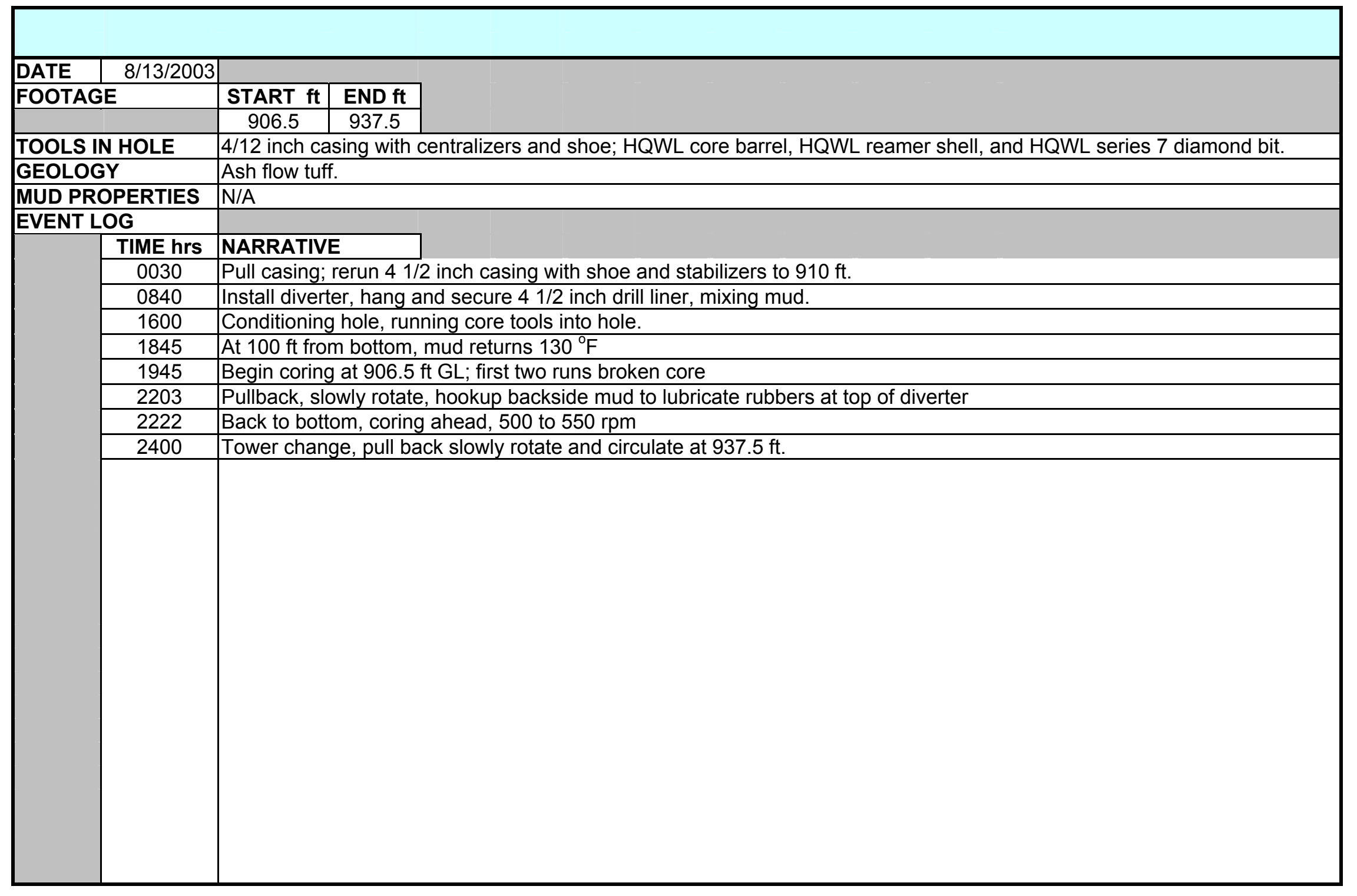




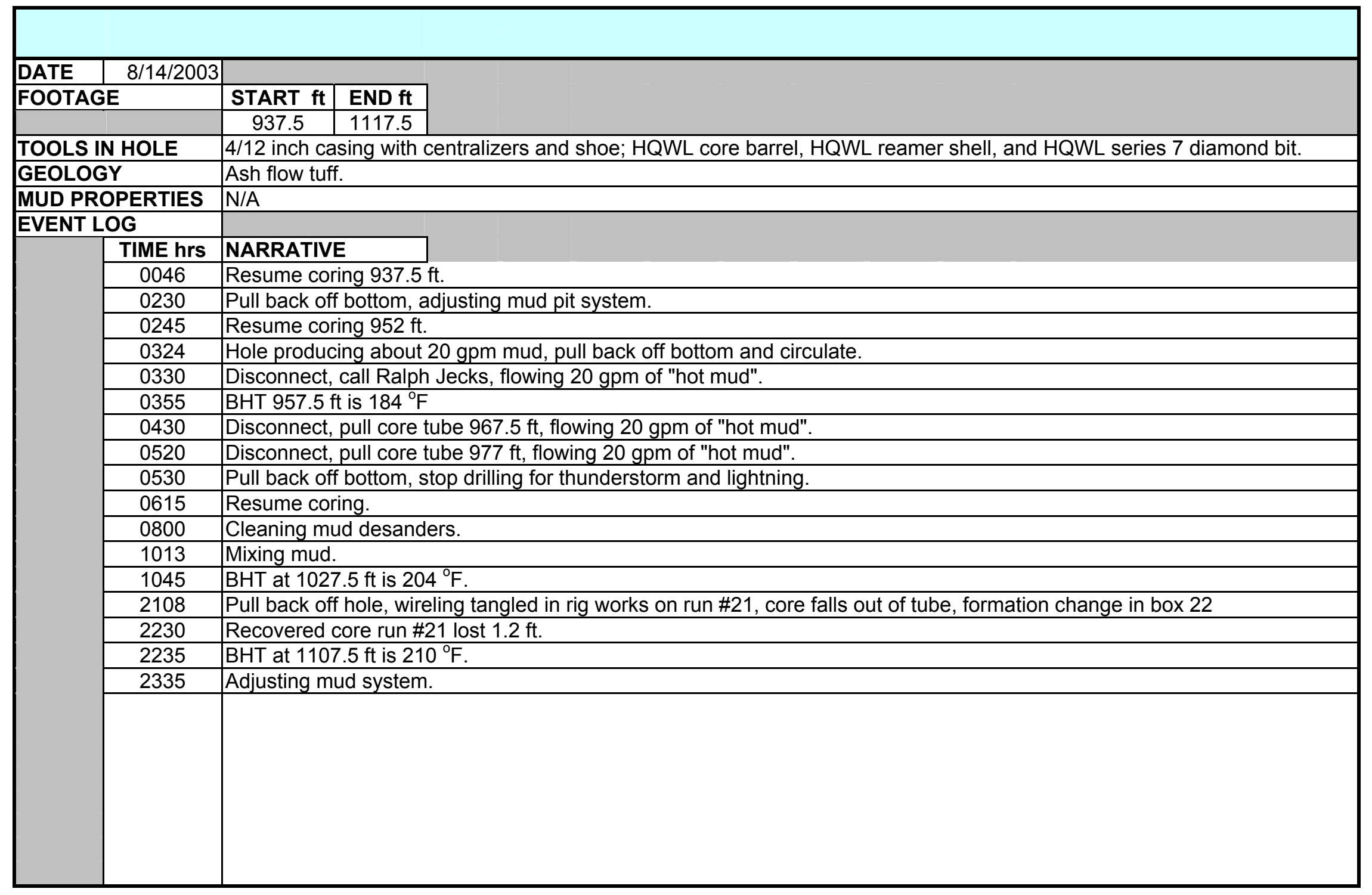




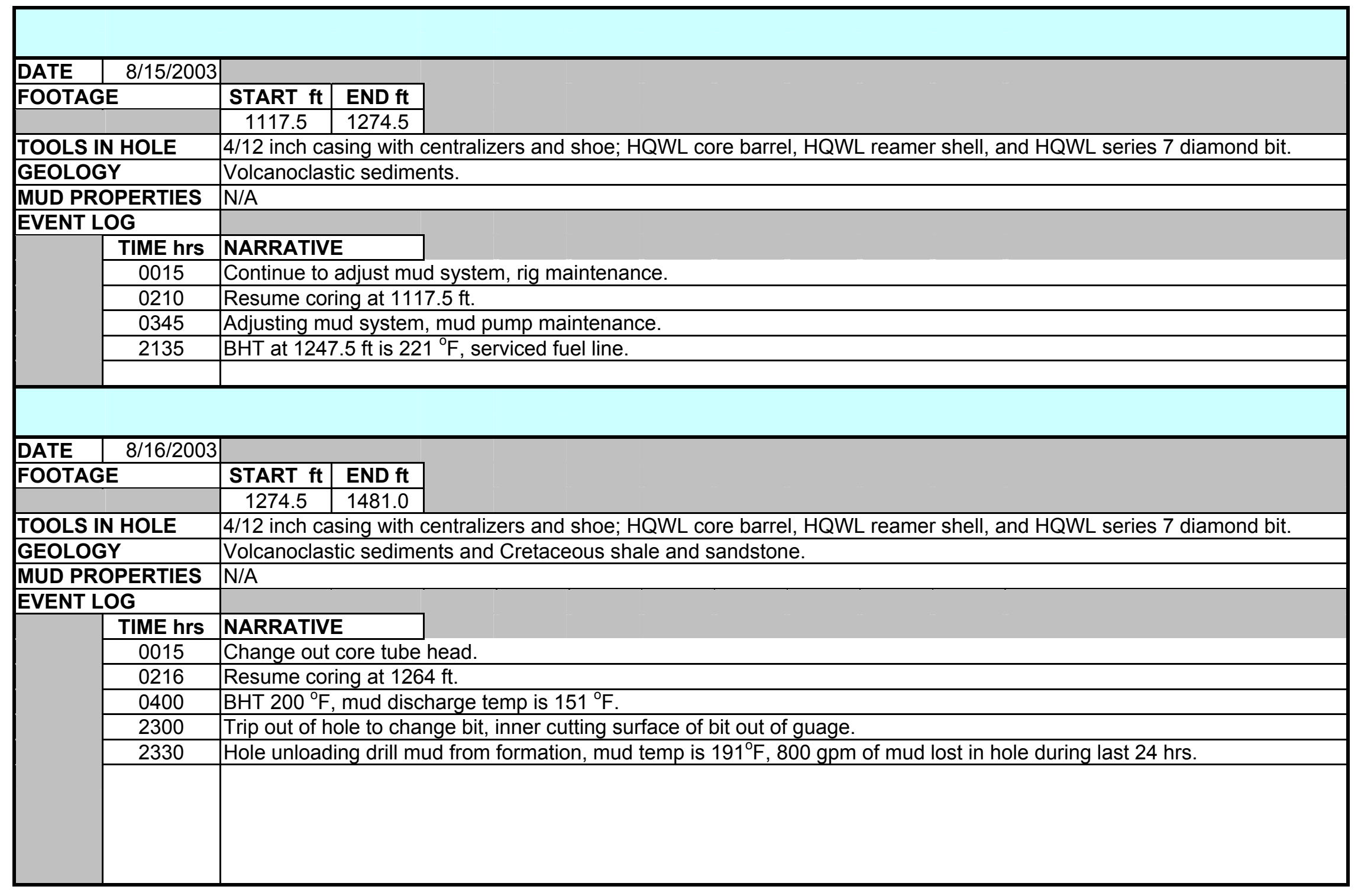




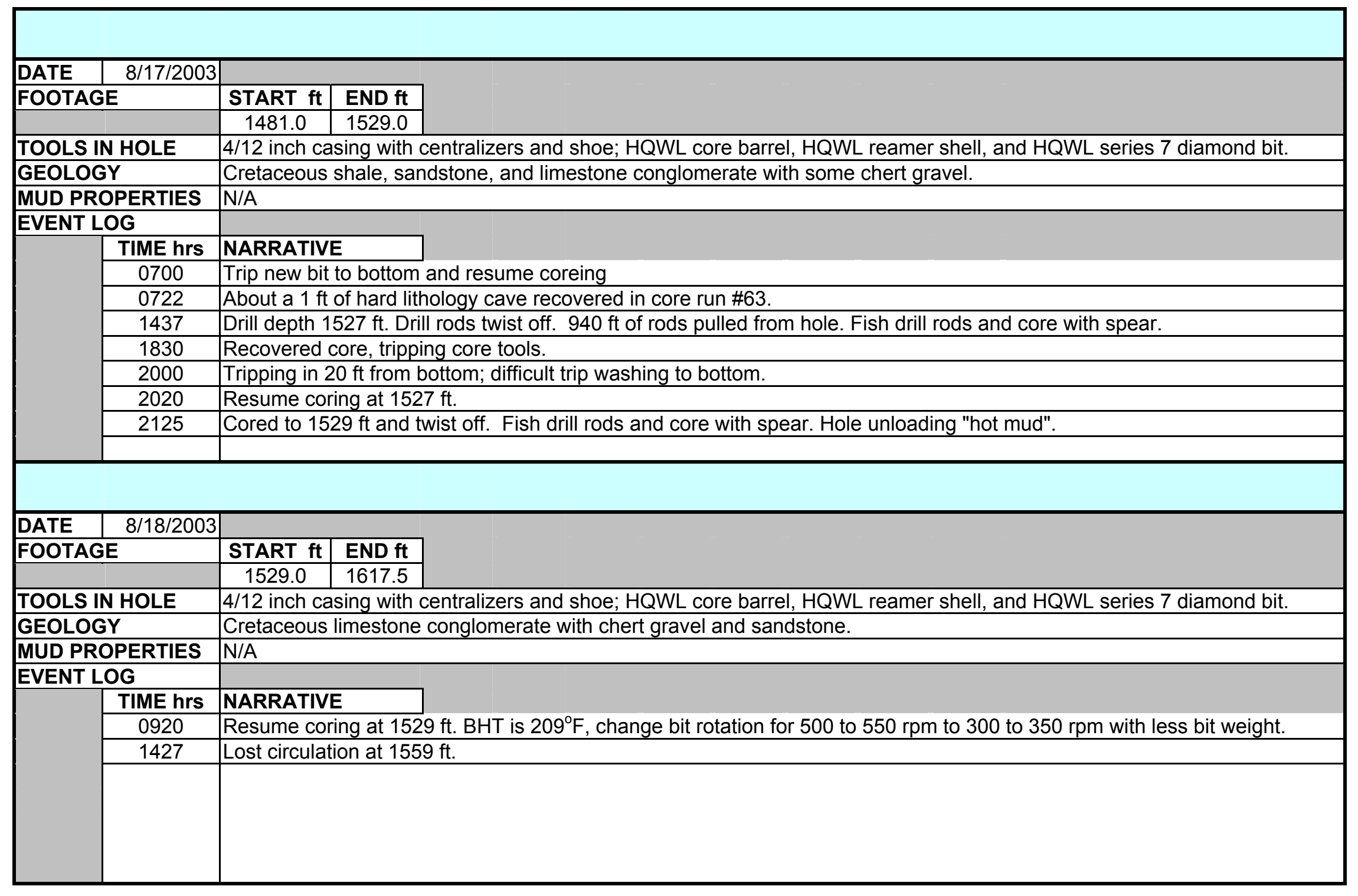




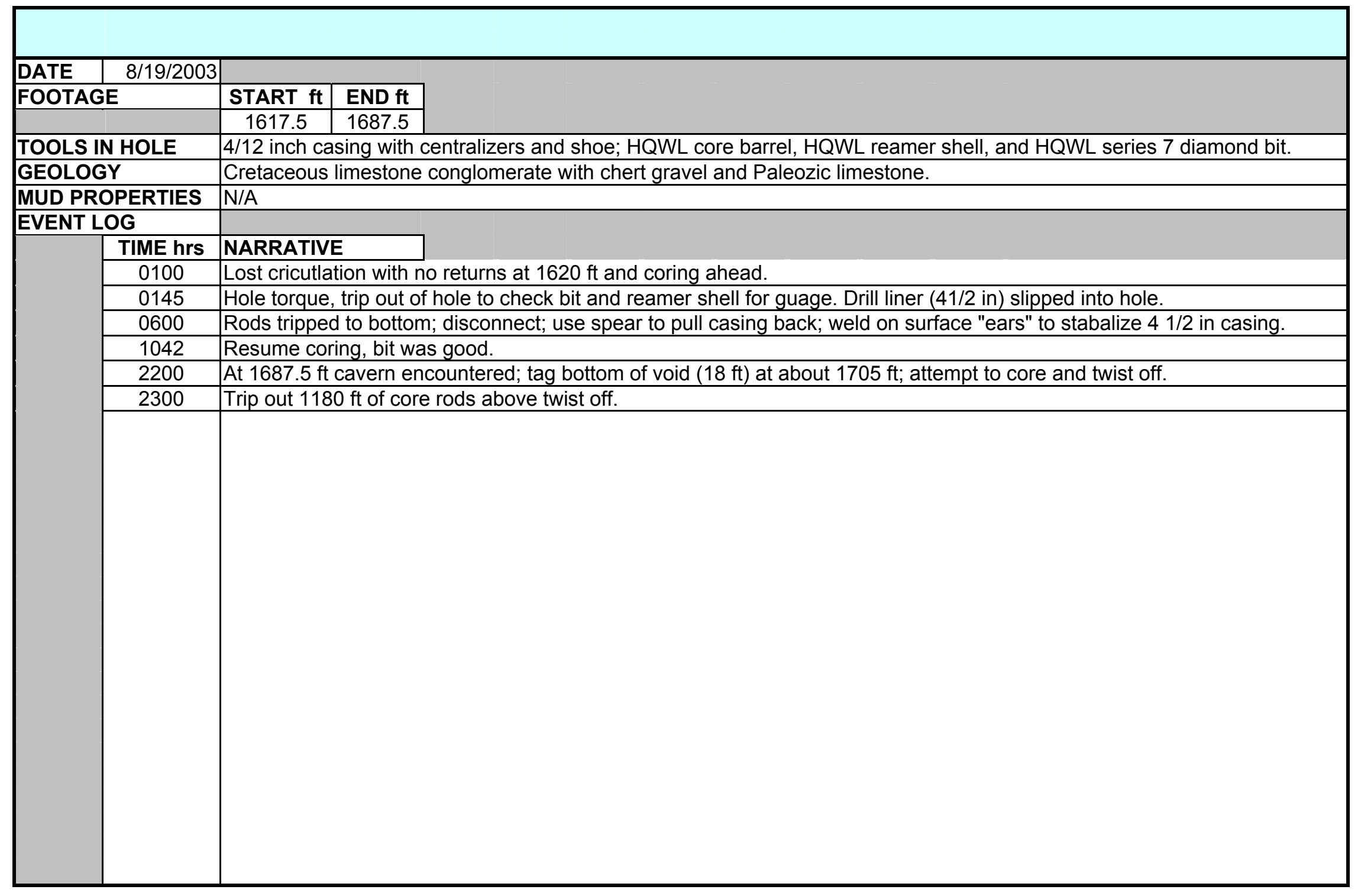




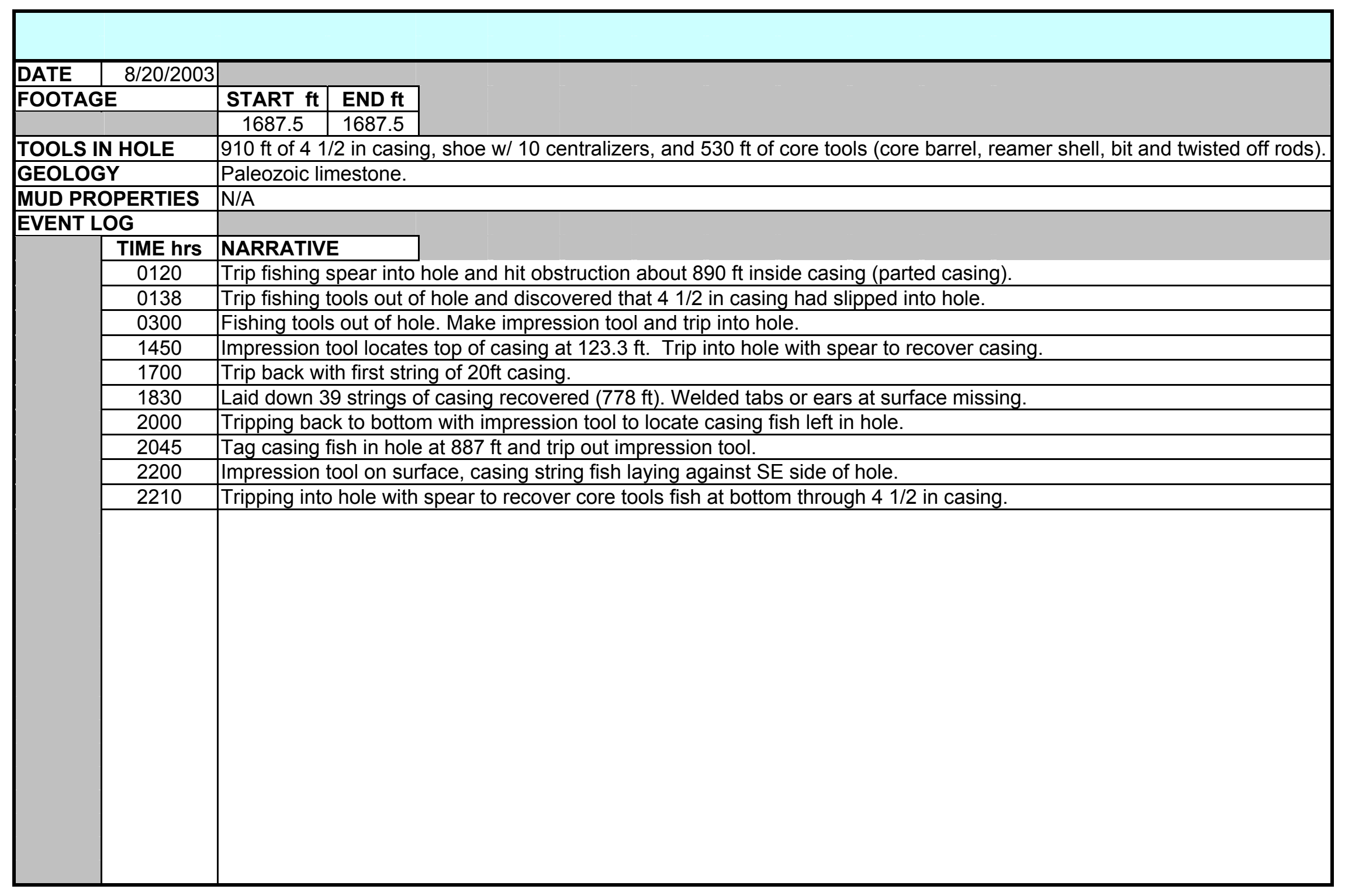




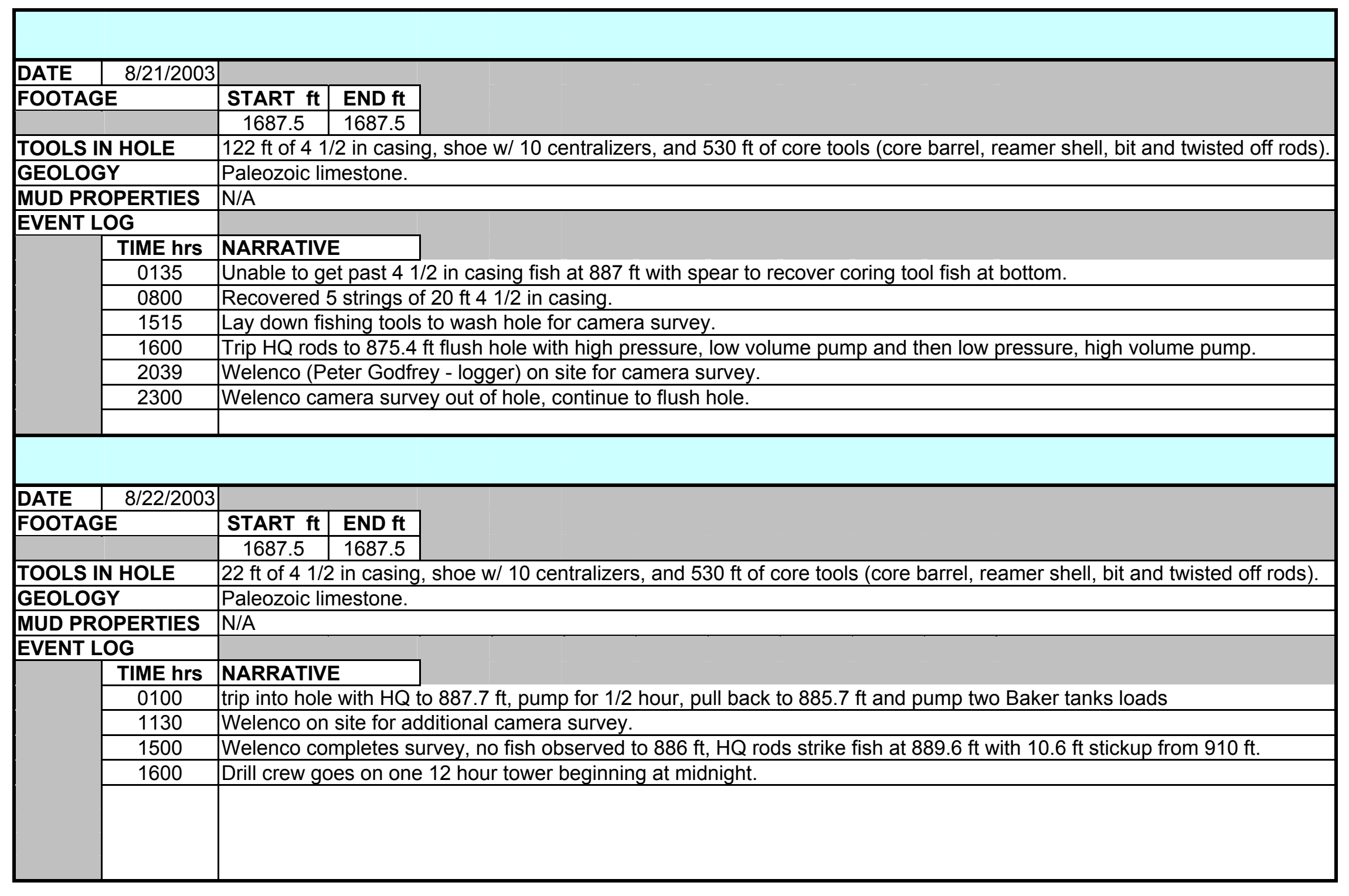




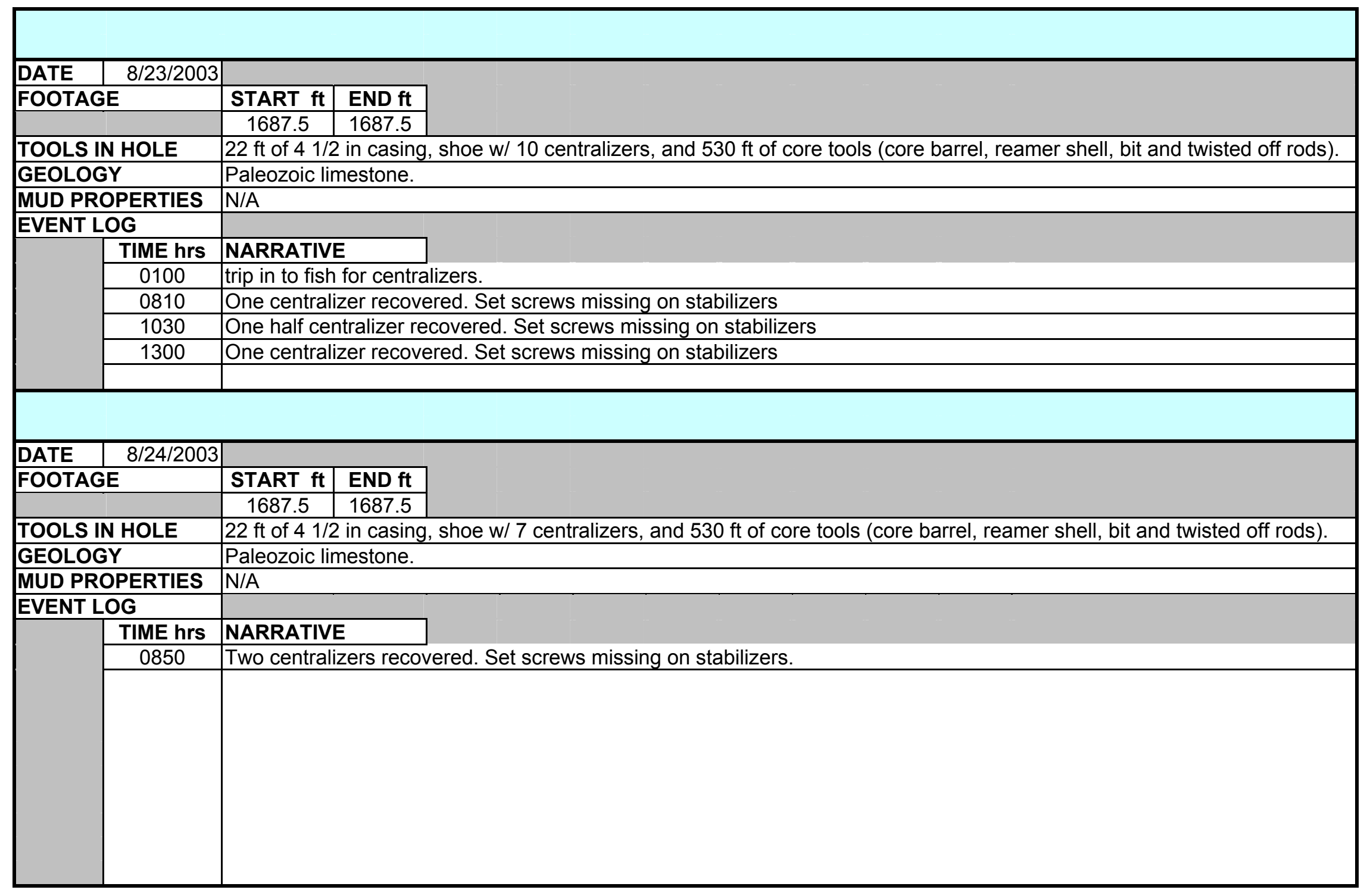




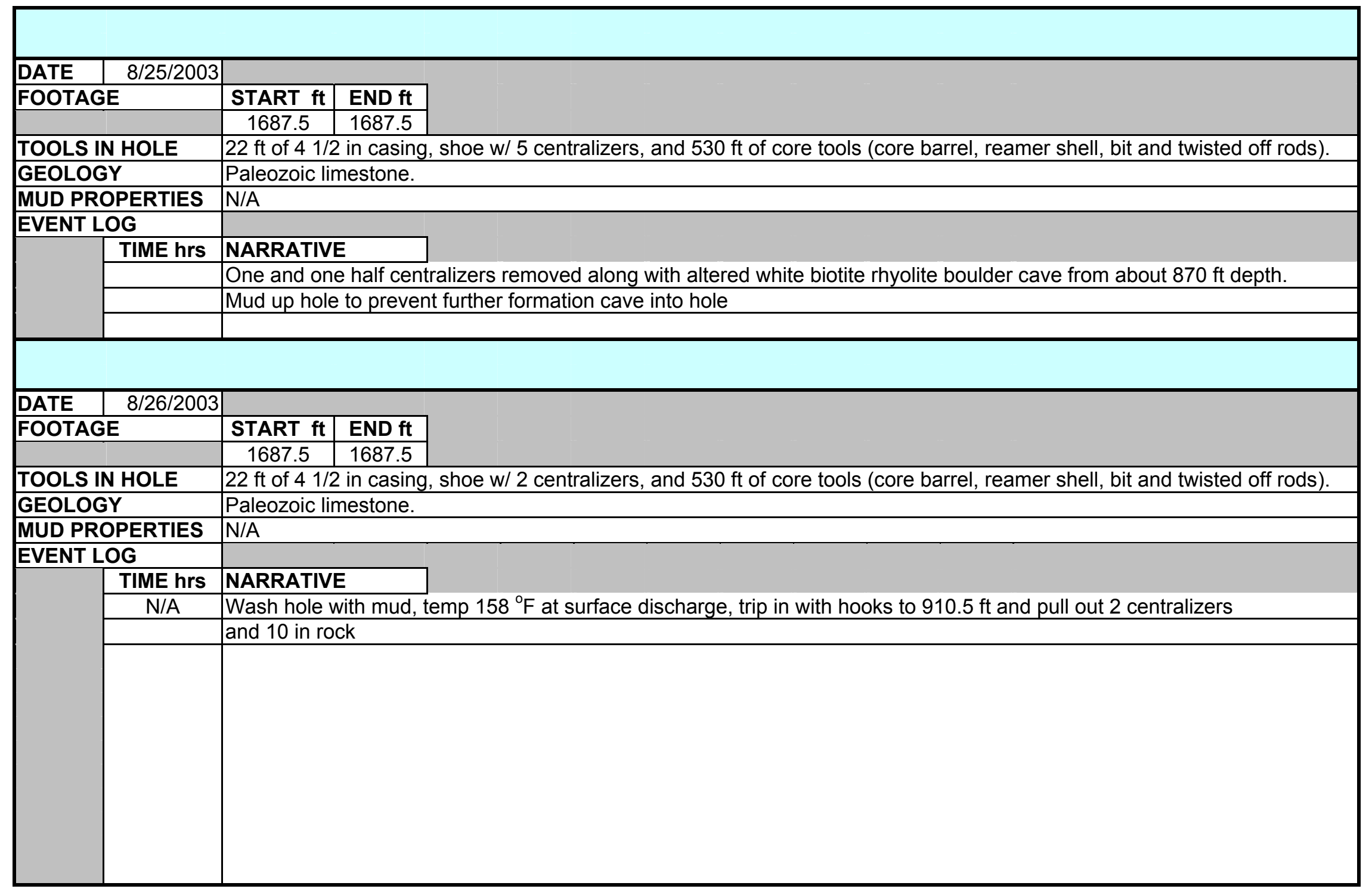




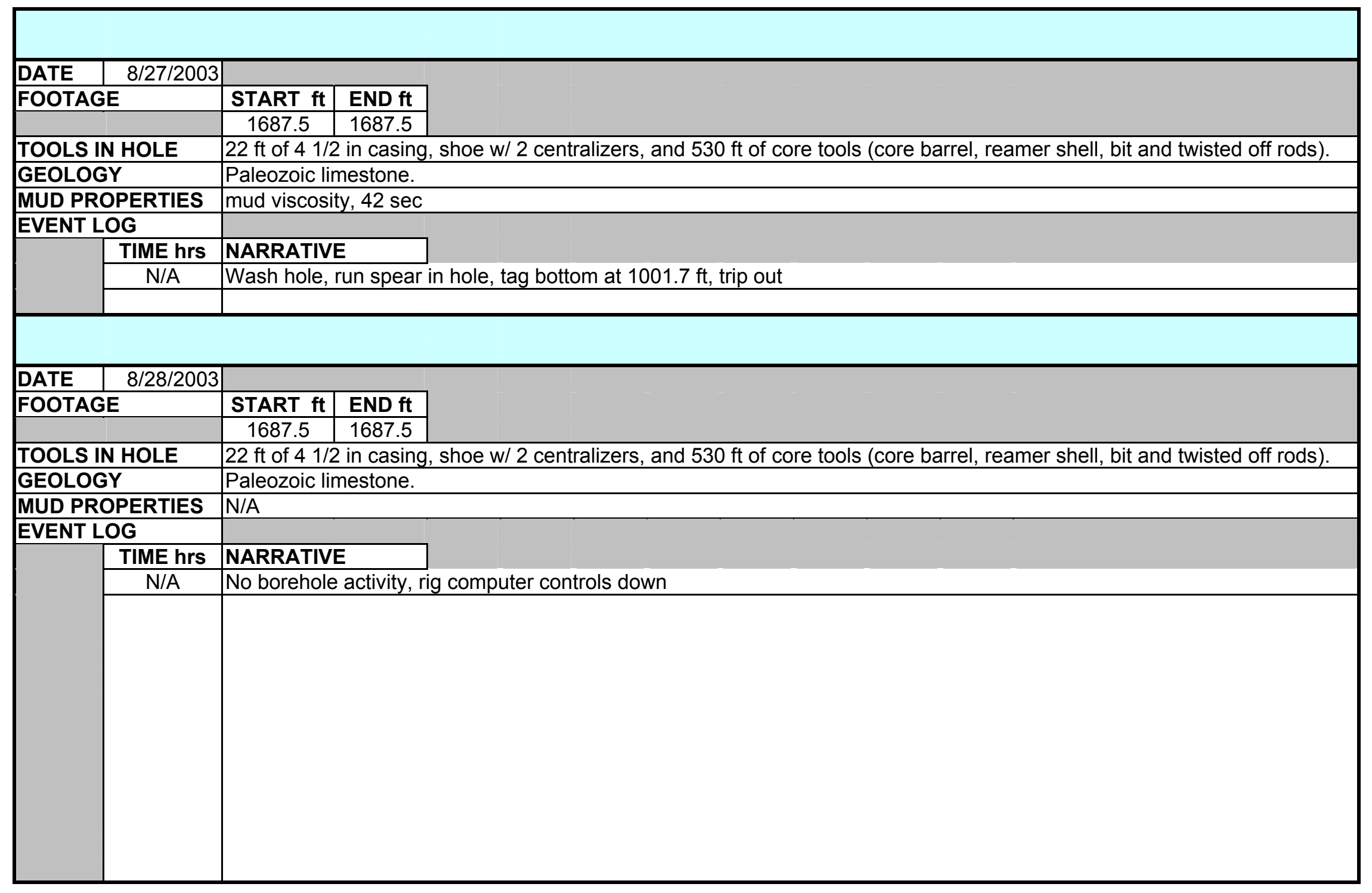




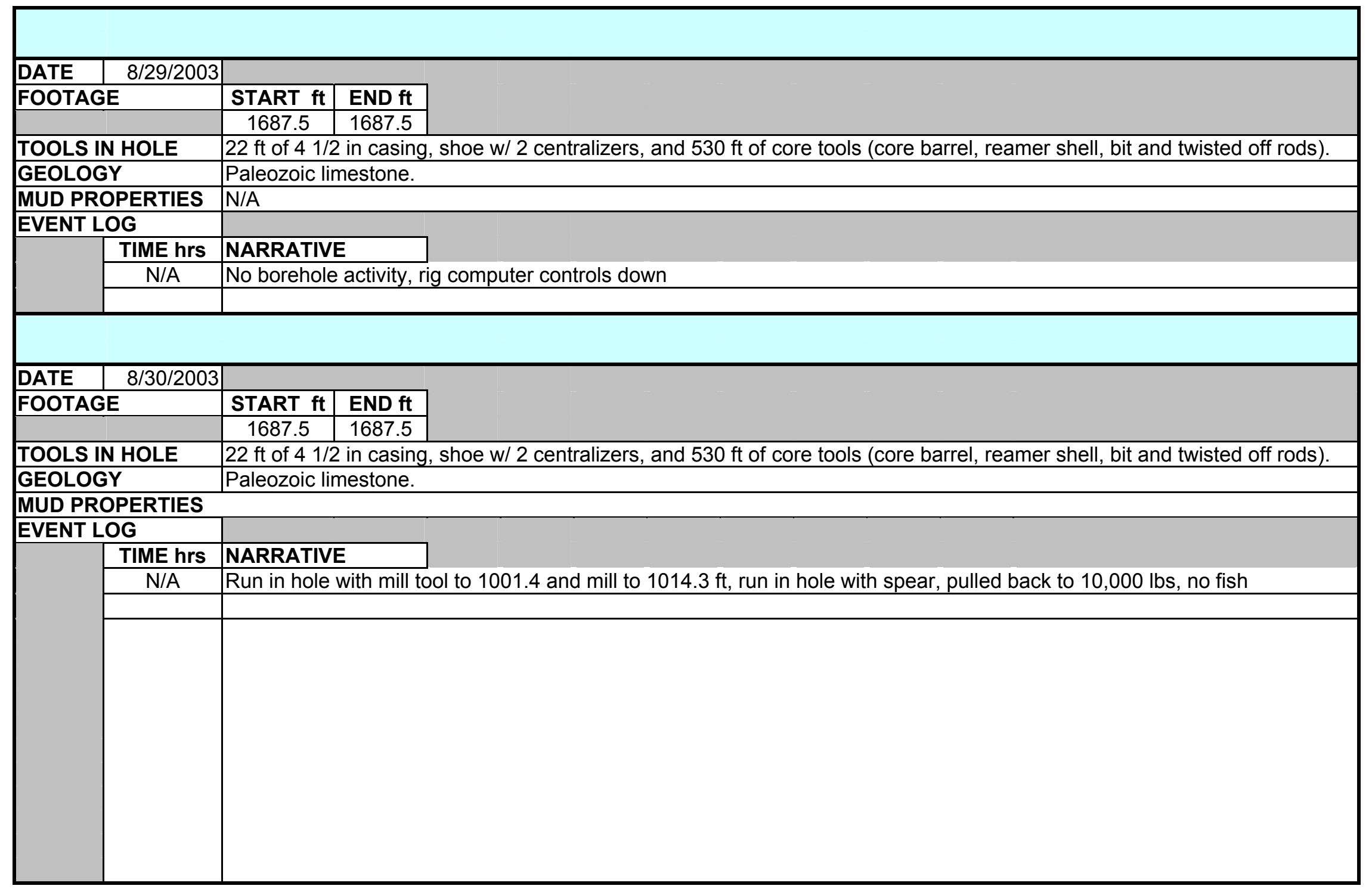




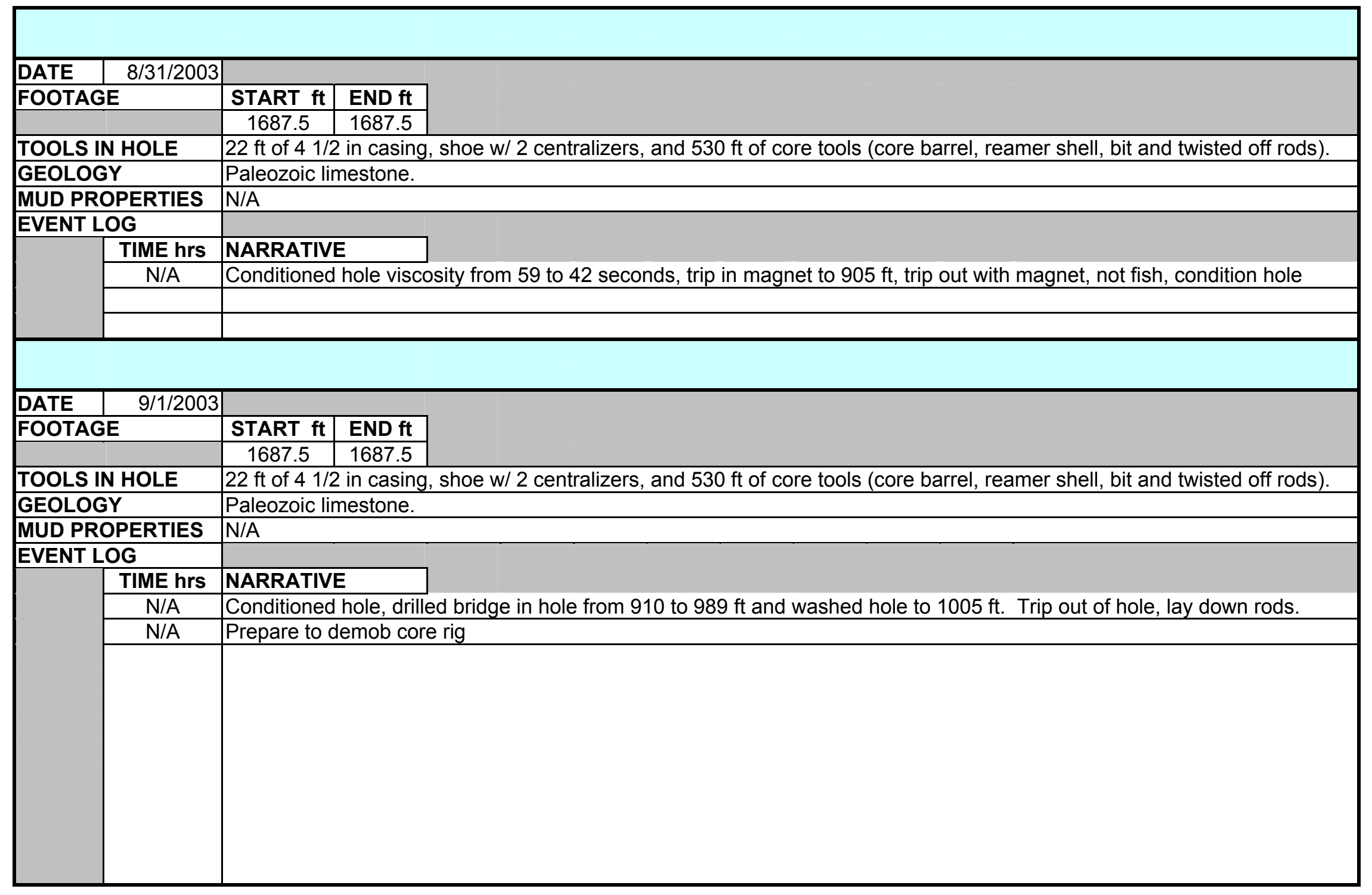




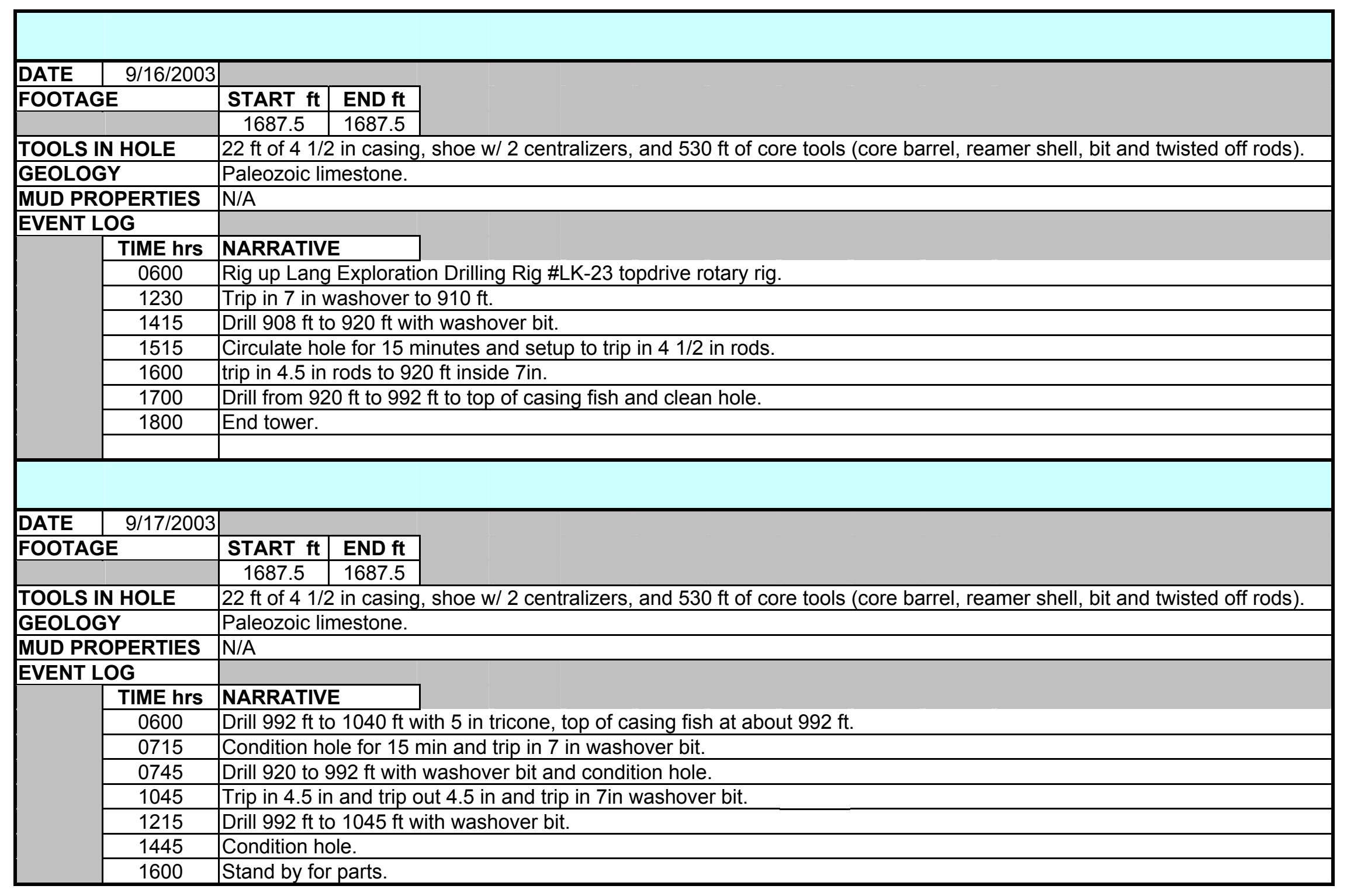




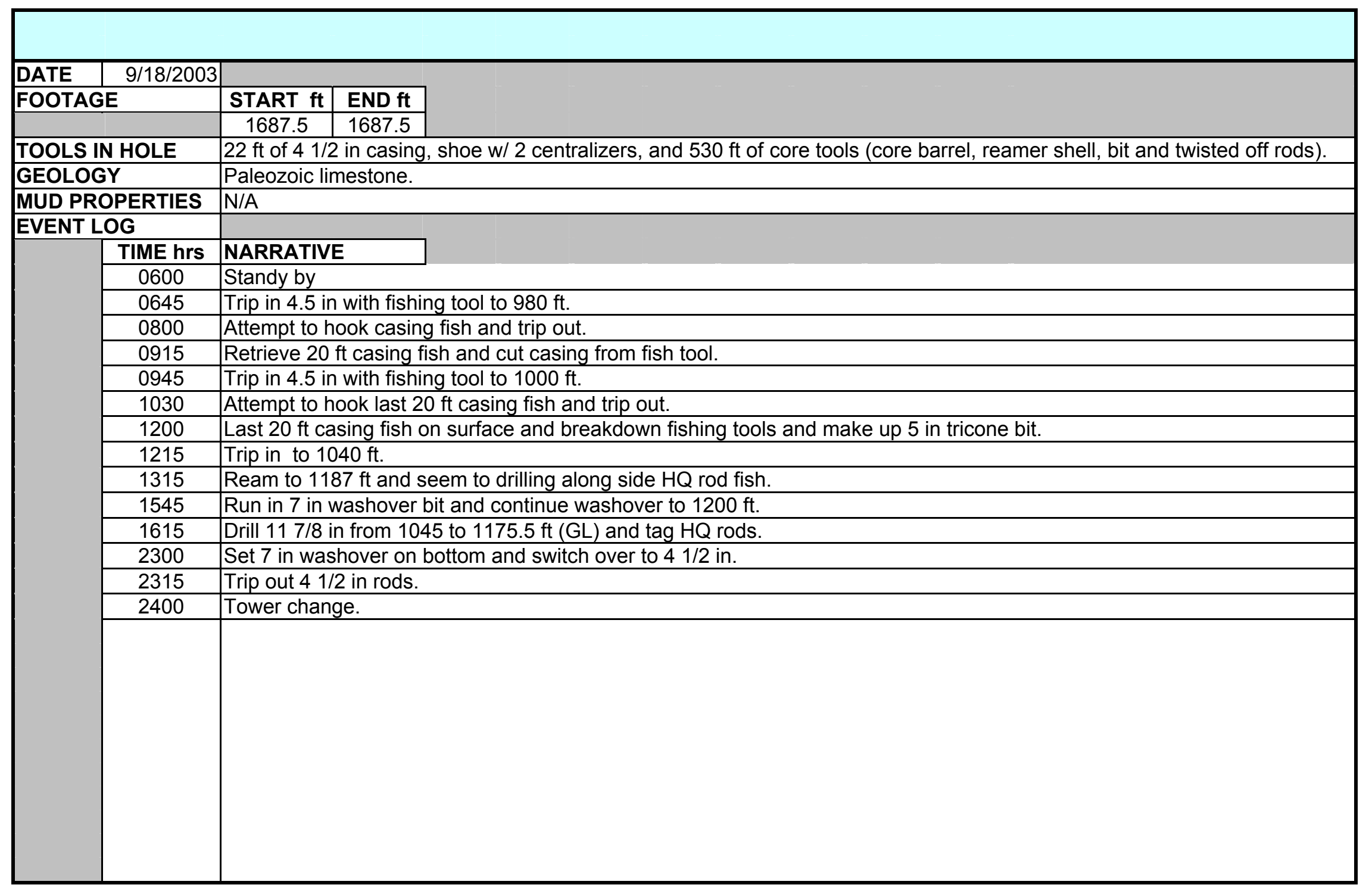




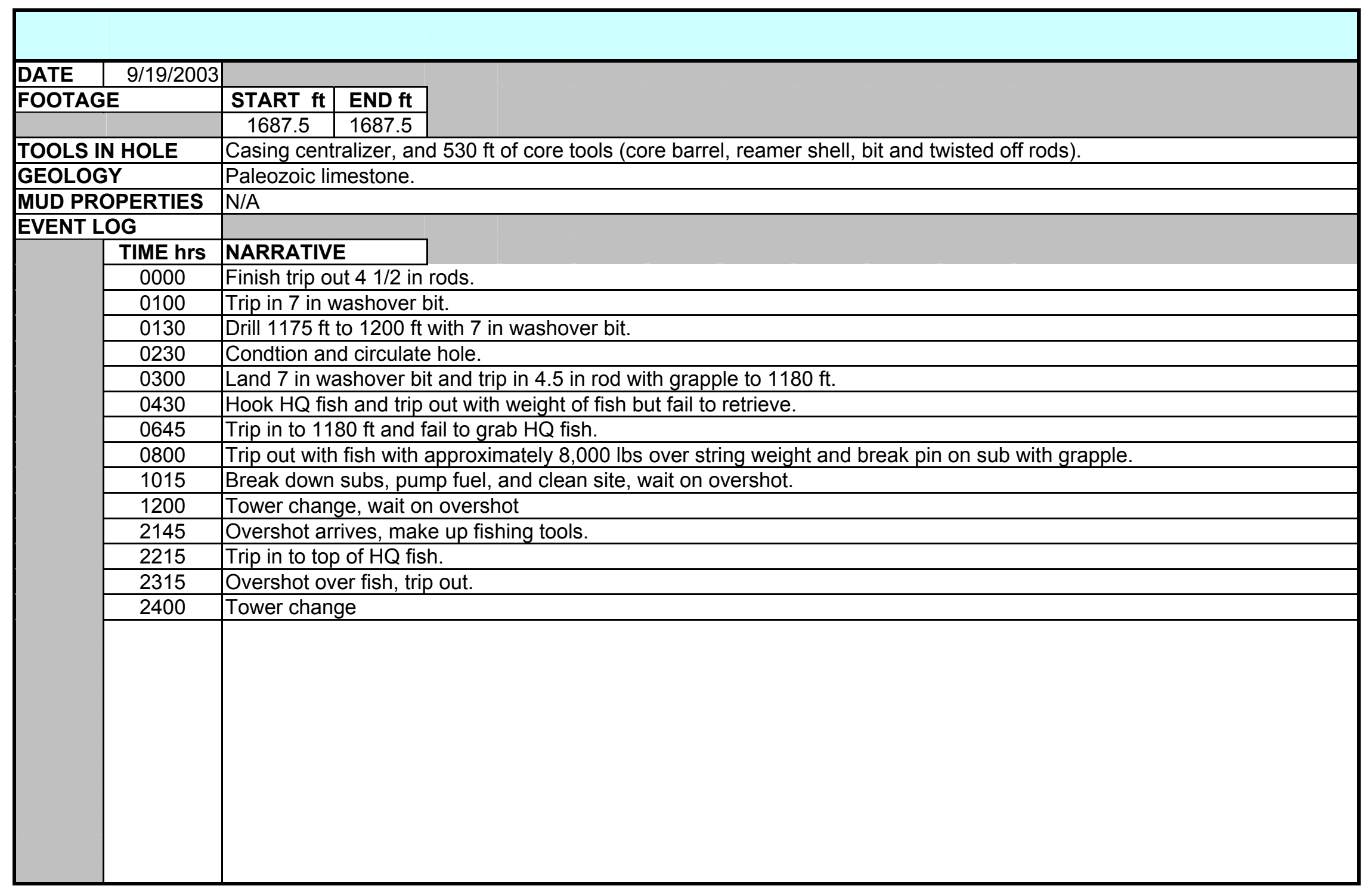




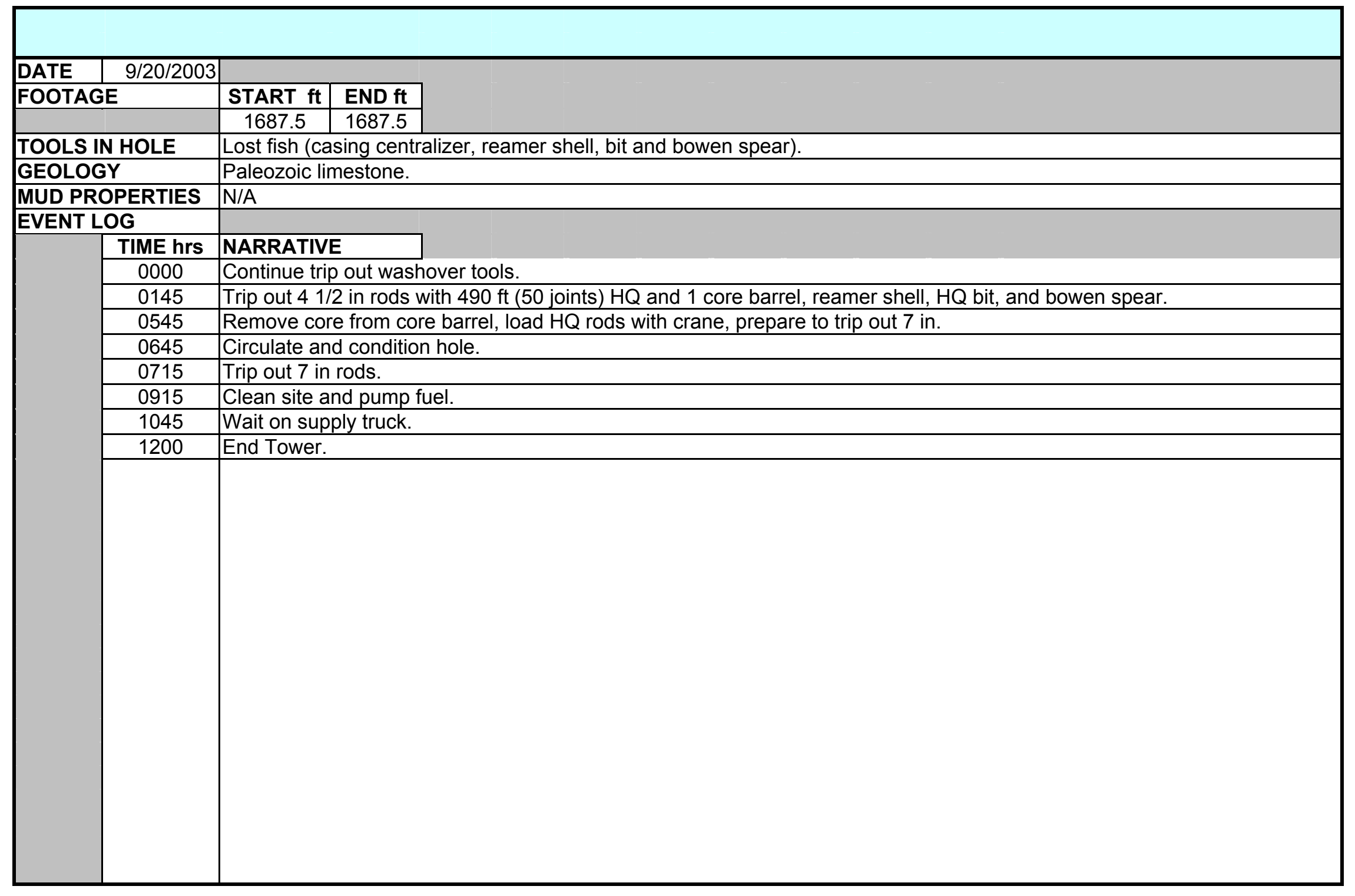




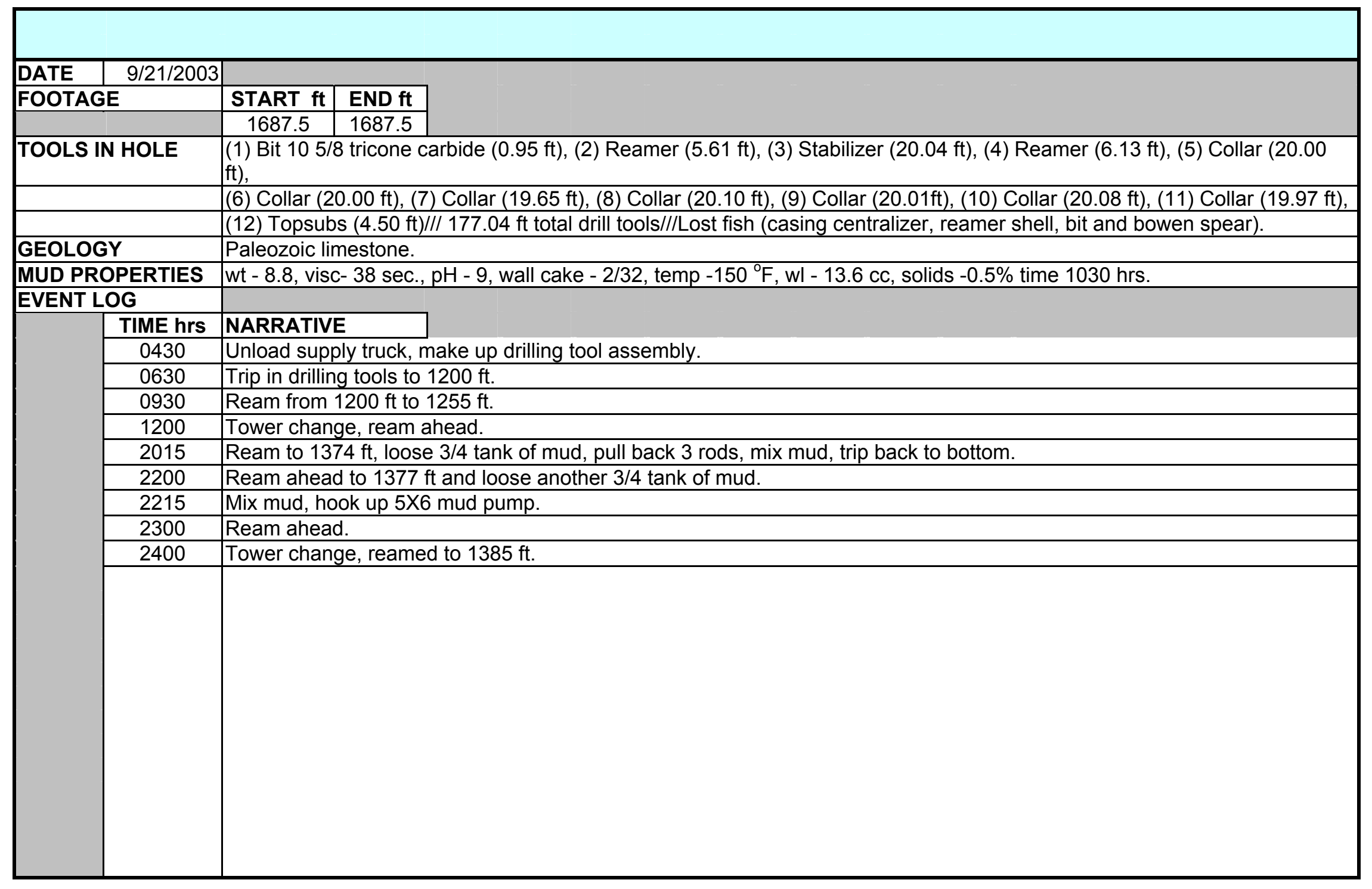




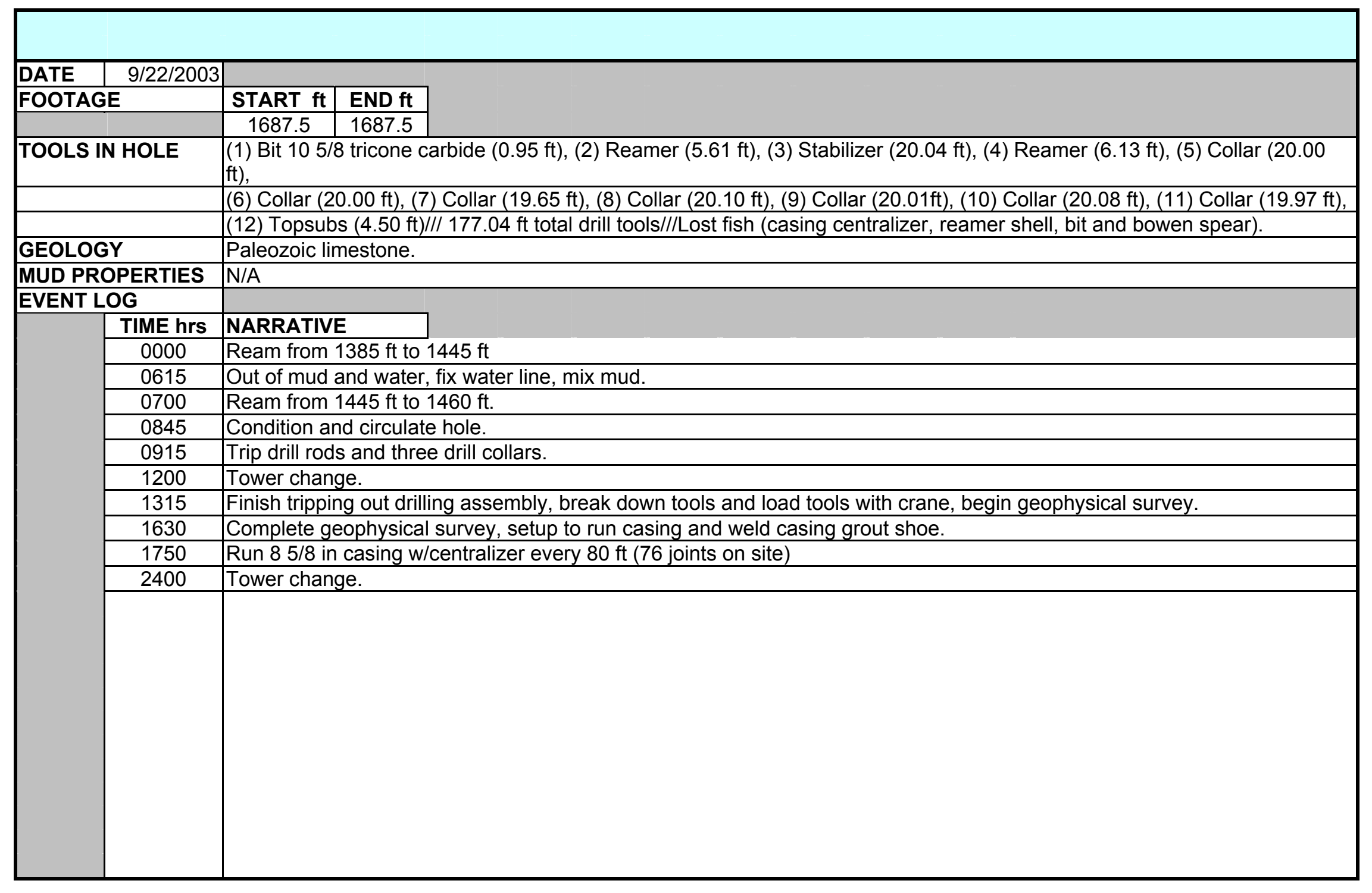




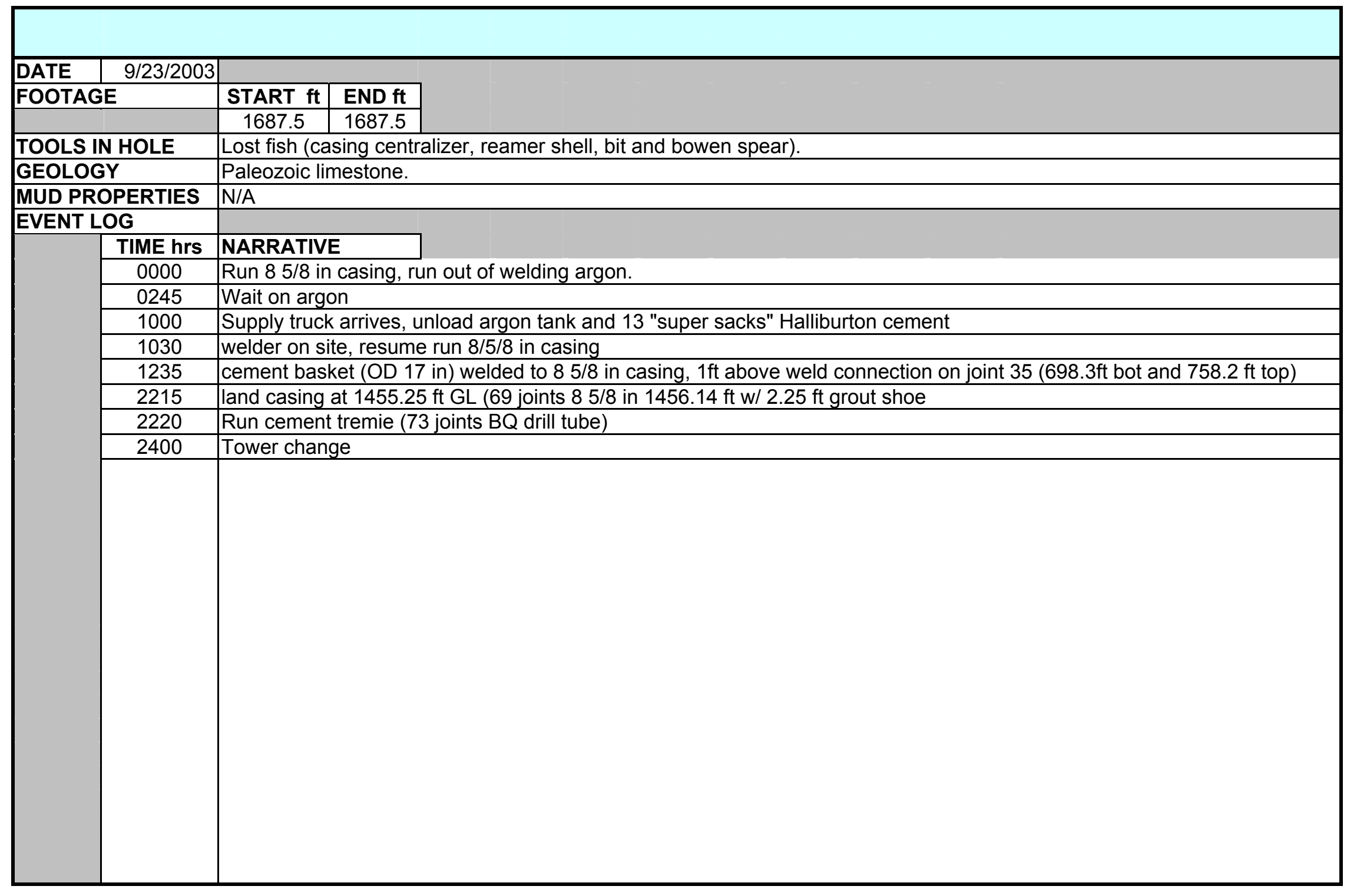




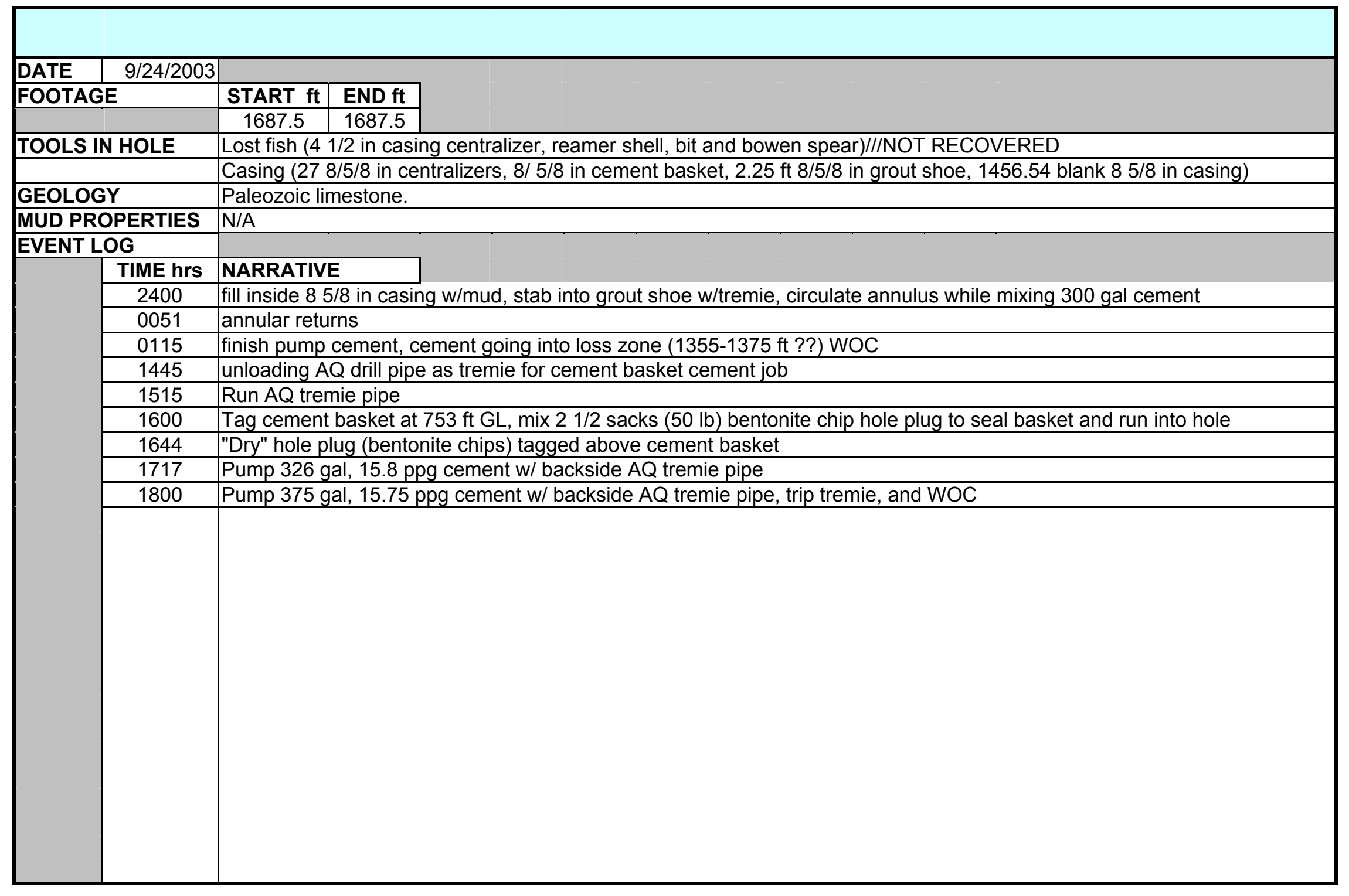




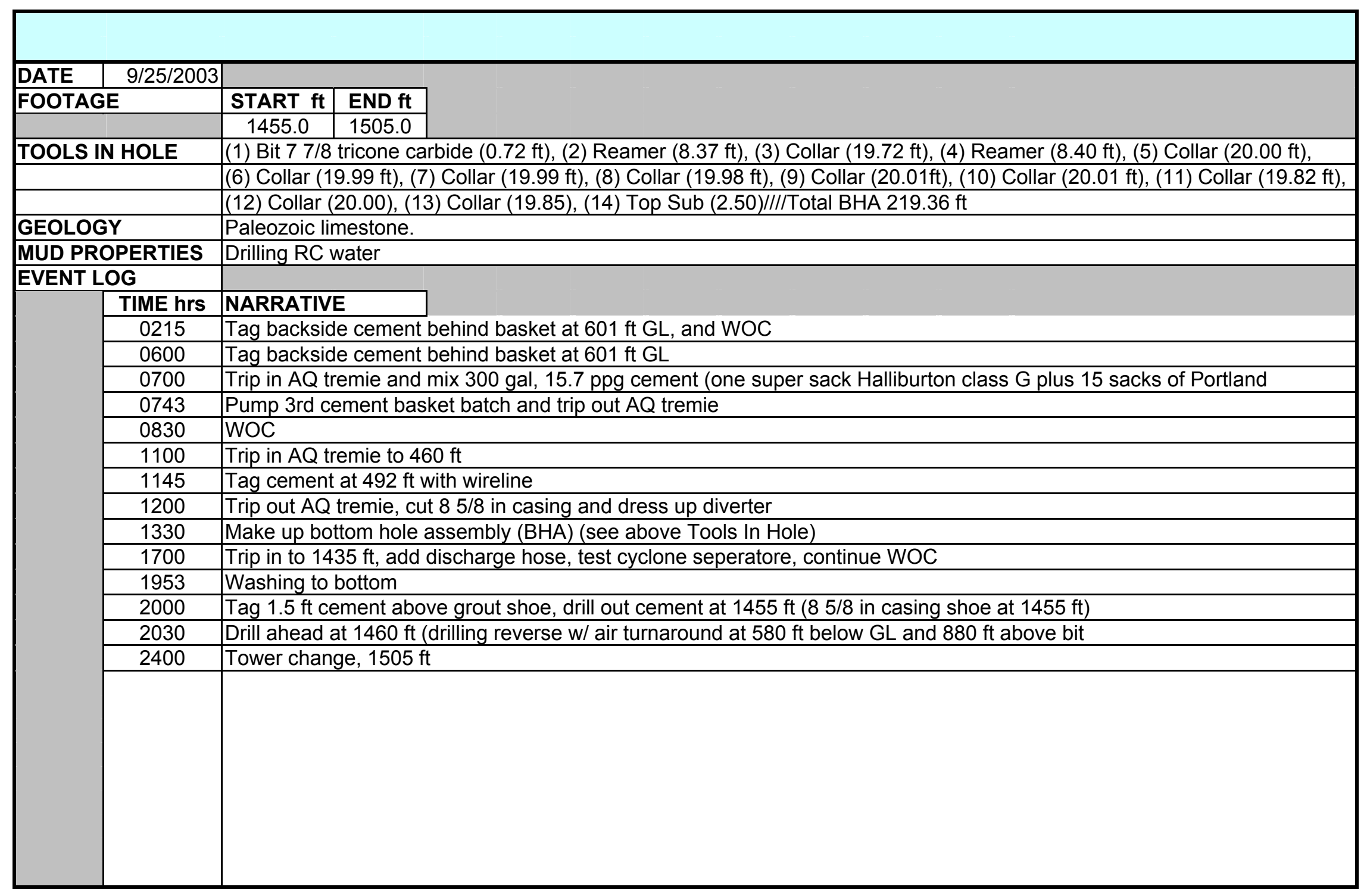




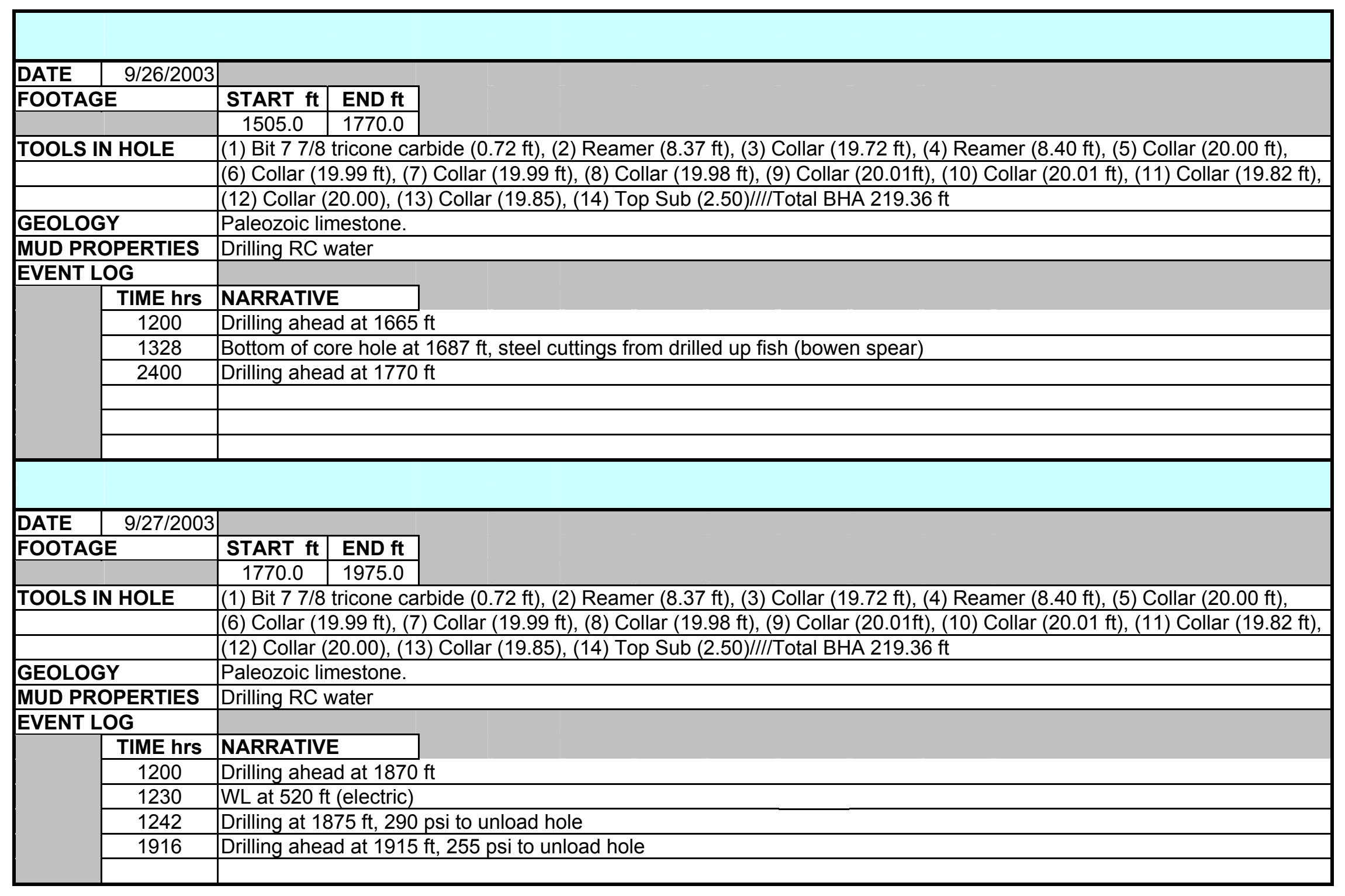




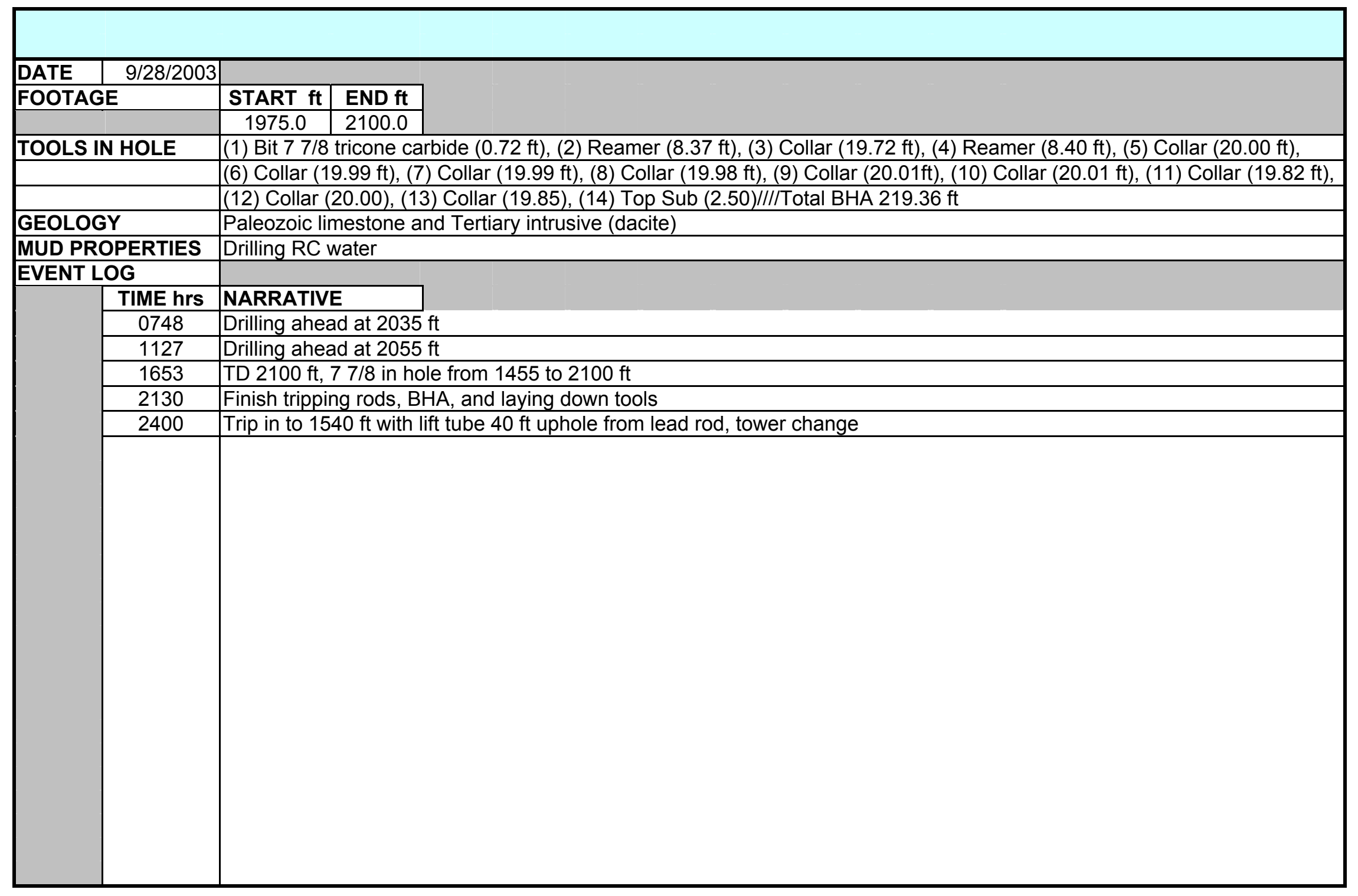




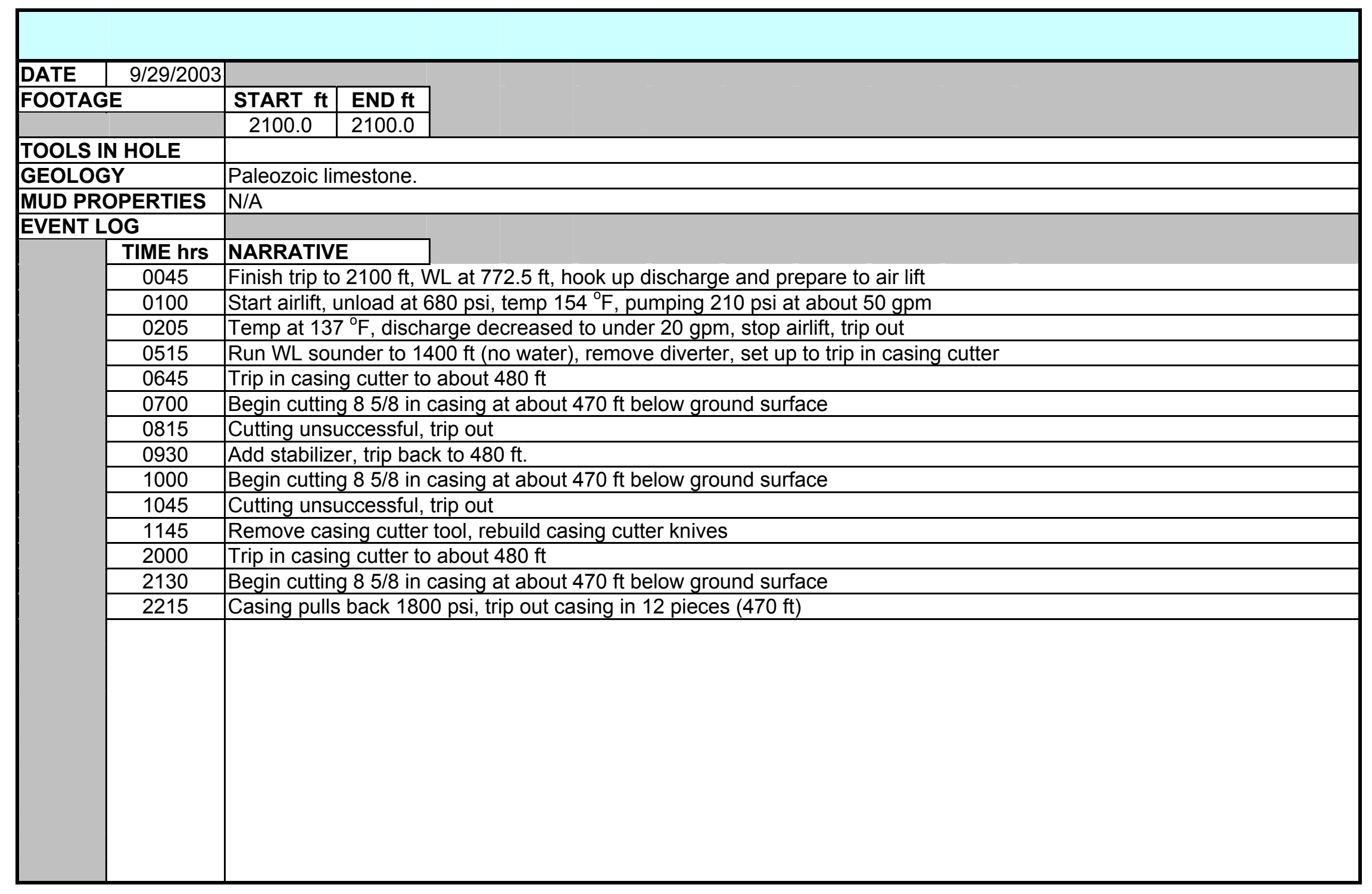




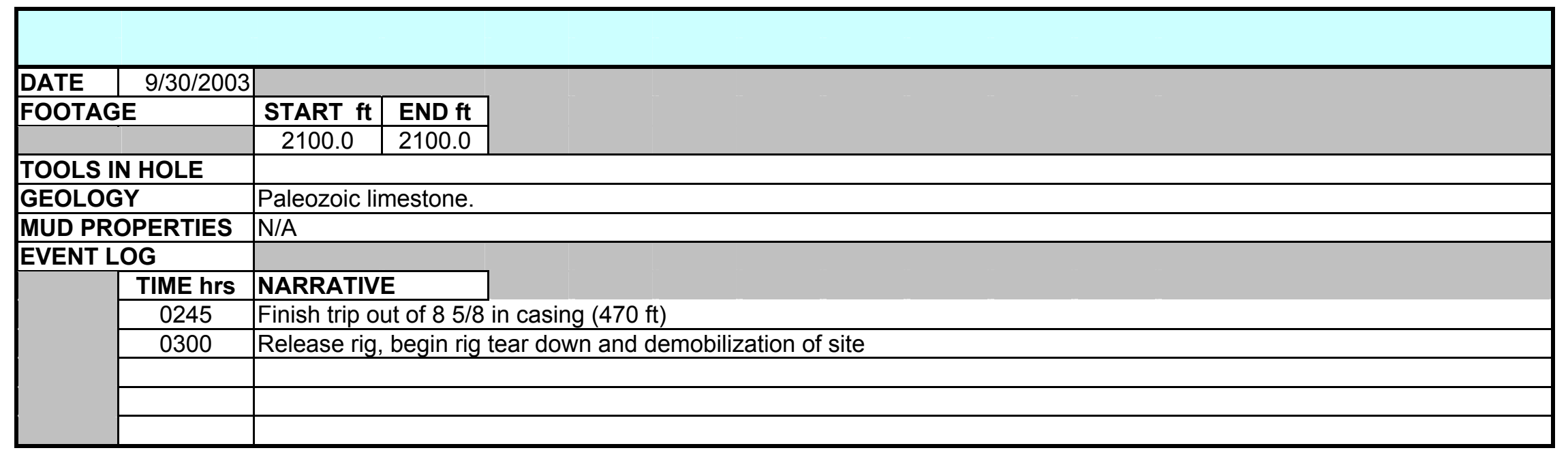




\section{APPENDIX 4 ISOTOPE NOMENCLATURE}

Hydrogen stable isotopes $(\delta D)$

$\delta \mathrm{D}$ analyses reported in $\%$ (permil) notation

$\delta \mathrm{D}(\%)=\left(\left({ }^{2} \mathrm{H} /{ }^{1} \mathrm{H}_{\text {sample }}\right) /\left({ }^{2} \mathrm{H} /{ }^{1} \mathrm{H}_{\text {standard }}\right)-1\right) \times 1000$

${ }^{2} \mathrm{H} /{ }^{1} \mathrm{H}_{\text {standard }}$ is VSMOW

(Vienna Standard Mean Ocean Water)

Oxygen stable isotopes $\left(\delta^{18} \mathrm{O}\right)$

$\delta^{18} \mathrm{O}$ analyses reported in $\%$ (permil) notation

$\delta^{18} \mathrm{O}\left({ }^{\circ} / \mathrm{oo}\right)=\left(\left({ }^{18} \mathrm{O} /{ }^{16} \mathrm{O}\right.\right.$ sample $) /\left({ }^{18} \mathrm{O} /{ }^{16} \mathrm{O}\right.$ standard $\left.)-1\right) \times 1000$

${ }^{18} \mathrm{O} /{ }^{16} \mathrm{O}_{\text {standard }}$ is V-SMOW

(Vienna Standard Mean Ocean Water)

Carbon stable isotopes $\left(\delta^{13} \mathrm{C}\right)$

$\delta^{13} \mathrm{C}$ analyses reported in $\%$ (permil) notation

$\delta^{13} \mathrm{C}\left(\%_{\circ}\right)=\left(\left({ }^{13} \mathrm{C} /{ }^{12} \mathrm{C}\right.\right.$ sample $) /\left({ }^{13} \mathrm{C} /{ }^{12} \mathrm{C}\right.$ standard $\left.)-1\right) \times 1000$

${ }^{13} \mathrm{C} /{ }^{12} \mathrm{C}_{\text {standard }}$ is $\mathrm{PDB}=0.011237$

(Pee Dee Belemnite)

Sulfur stable isotopes $\left(\delta^{34} S\right)$

$\delta^{34} \mathrm{~S}$ analyses reported in \% (permil) notation

$\delta^{34} \mathrm{~S}\left({ }^{\%} \%\right)=\left(\left({ }^{34} \mathrm{~S} /{ }^{32} \mathrm{~S}\right.\right.$ sample $\left.) /\left({ }^{34} \mathrm{~S} /{ }^{32} \mathrm{~S}_{\text {standard }}\right)-1\right) \times 1000$

${ }^{34} \mathrm{~S} /{ }^{32} \mathrm{~S}_{\text {standard }}$ is CDT $=0.0450045$

(Canyon Diablo Troilite)

Strontium isotopes $\left({ }^{87} \mathrm{Sr} /{ }^{86} \mathrm{Sr}\right)$

${ }^{87} \mathrm{Sr} /{ }^{86} \mathrm{Sr}$ analyses reported as ratio ${ }^{87} \mathrm{Sr} /{ }^{86} \mathrm{Sr}$

NIST SRM 987 Sr standard $=0.710265$ 